
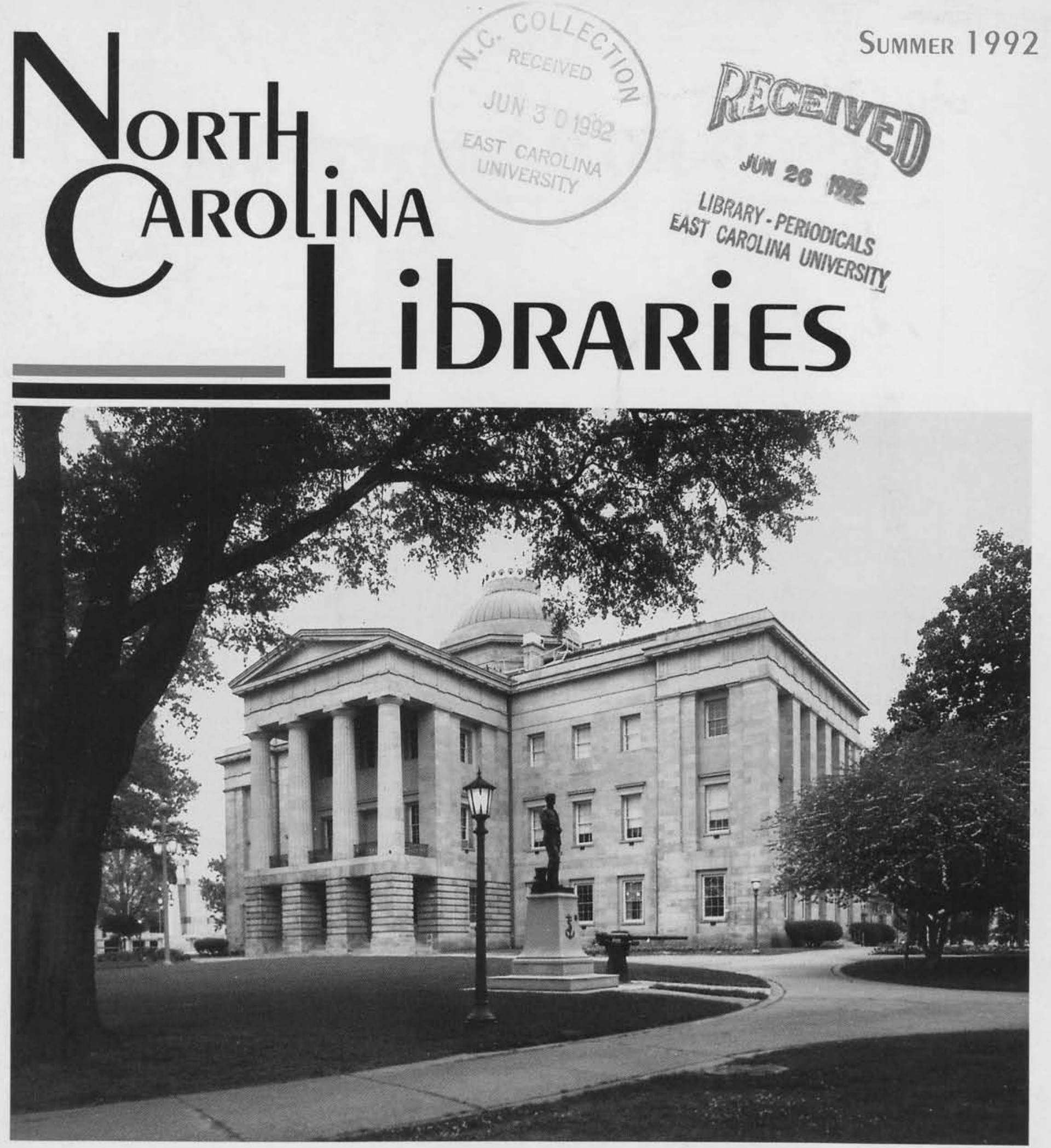

Librarians must overcome their timidness in order to discover the political attitudes of candidates. Librarians must secure the active support of library board members and friends of libraries to elect Legislators who comprehend the importance of public libraries in the democratic way of life. The success of a legislative program depends more upon work done before the Legislators go to Raleigh than it does upon requests and oratory during Legislative Sessions. 


\section{Introducing: \\ SIRS CD-ROM Library Network}

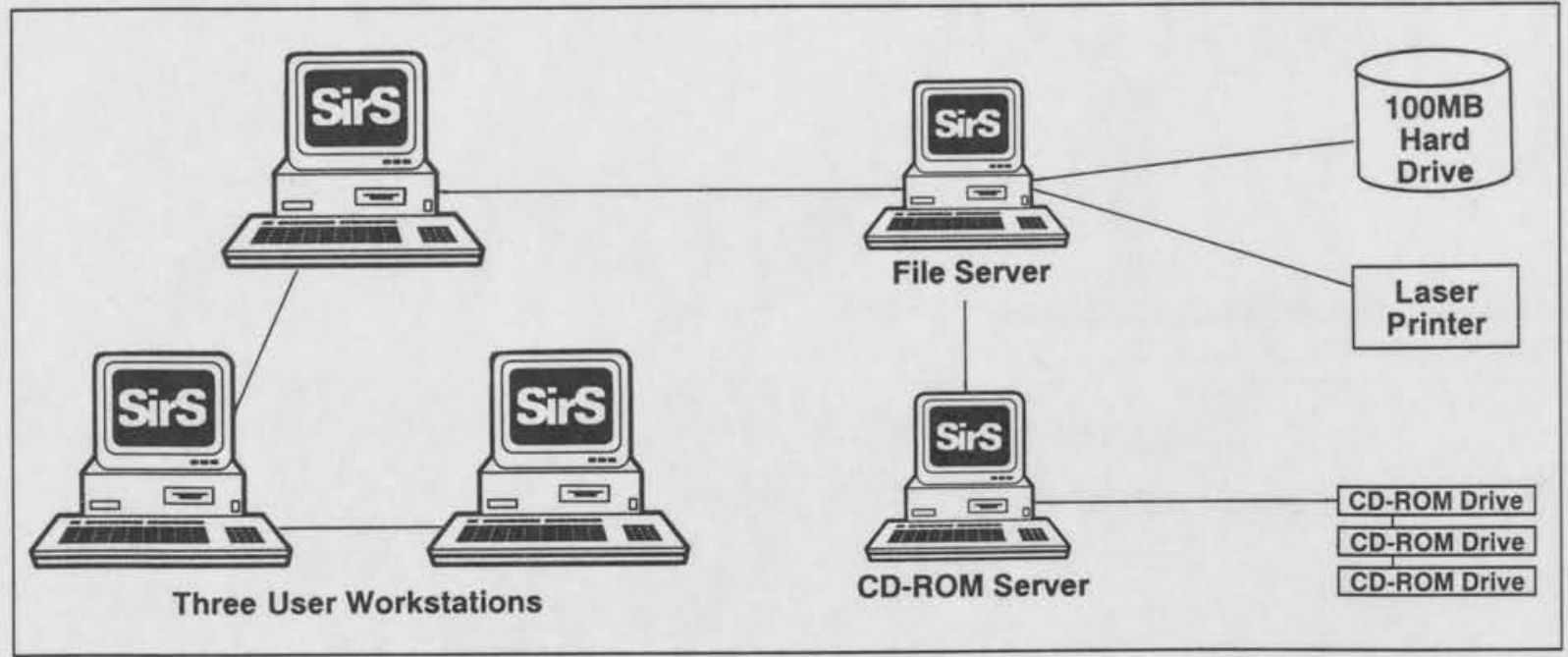

The SIRS CD-ROM Library Network is a highspeed, high-quality local area network (LAN) package. The trio of workstations can access any of three CD-ROM drives simultaneously. The 100 megabyte (MB) hard drive can accommodate several software programs. This basic turn-key network is Novell*-based, which ensures easy expandability of workstations and CD-ROM drives.

Installed on the network is SIRS Combined Text \& Index CD-ROM: a database offering over 5,000 full-text articles pertaining to social science and science topics. This easy-to-use format provides instantaneous access to thousands of articles from hundreds of national and international sources. Full-text articles may be viewed on-screen and, if desired, printed or down-loaded as full or partial text.

The LAN package is priced at $\$ 13,500$, and includes first annual subscription to SIRS Combined Text \& Index CD-ROM. Alternative hardware configuraSocial tions can be designed

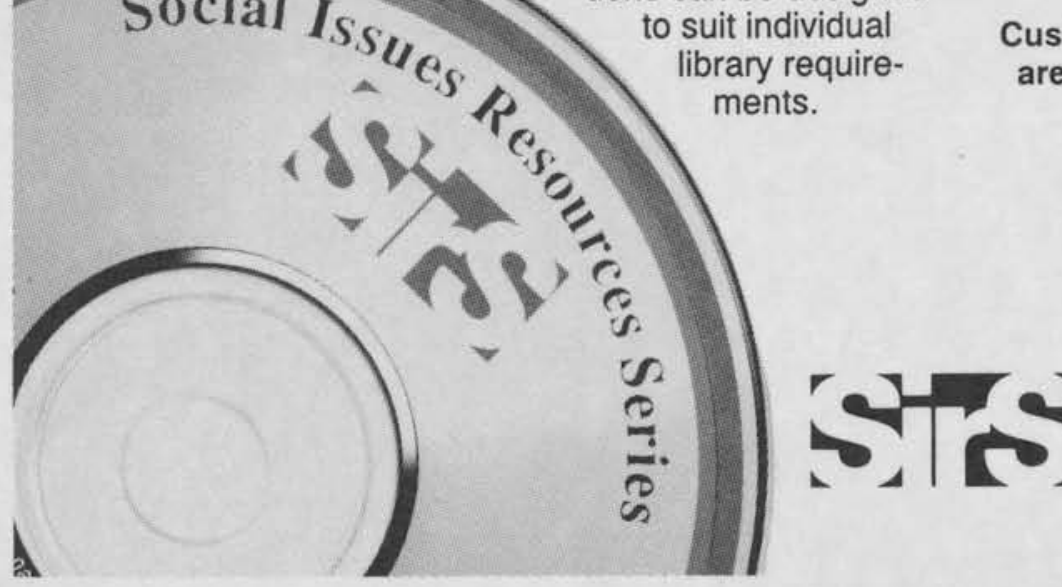

The Network Includes:

- Three 386SX (25 MHz) computer workstations (with VGA color monitors, enhanced keyboards), each with 1 MB RAM

- Two 386SX (25 MHz) computers for exclusive use as file server and CD-ROM server, each with 3 MB RAM

^ Three CD-ROM drives

A $100 \mathrm{MB}$ hard drive

^One laser printer

\ Novell Netware*

A CBIS CD-Connection** software (10-user license fee included)

A DOS 5.0

^ SIRS Combined Text \& Index CD-ROM

Customer Service and Hardware Consultants are available 9 a.m. to 6 p.m., Eastern Time to answer your questions. Call Toll-Free: $1-800-374-S I R S$

- Novell and Netware are trademarks of Novell, Inc.

* CBIS and CD.Connection are trademarks of CBIS, Inc.

SOCIAL ISSUES RESOURCES SERIES, INC.

P.O. BOX 2348

BOCA RATON, FL 33427-2348

TOLL-FREE: $1-800-374$ SIRS • FAX: 407-994-4704 


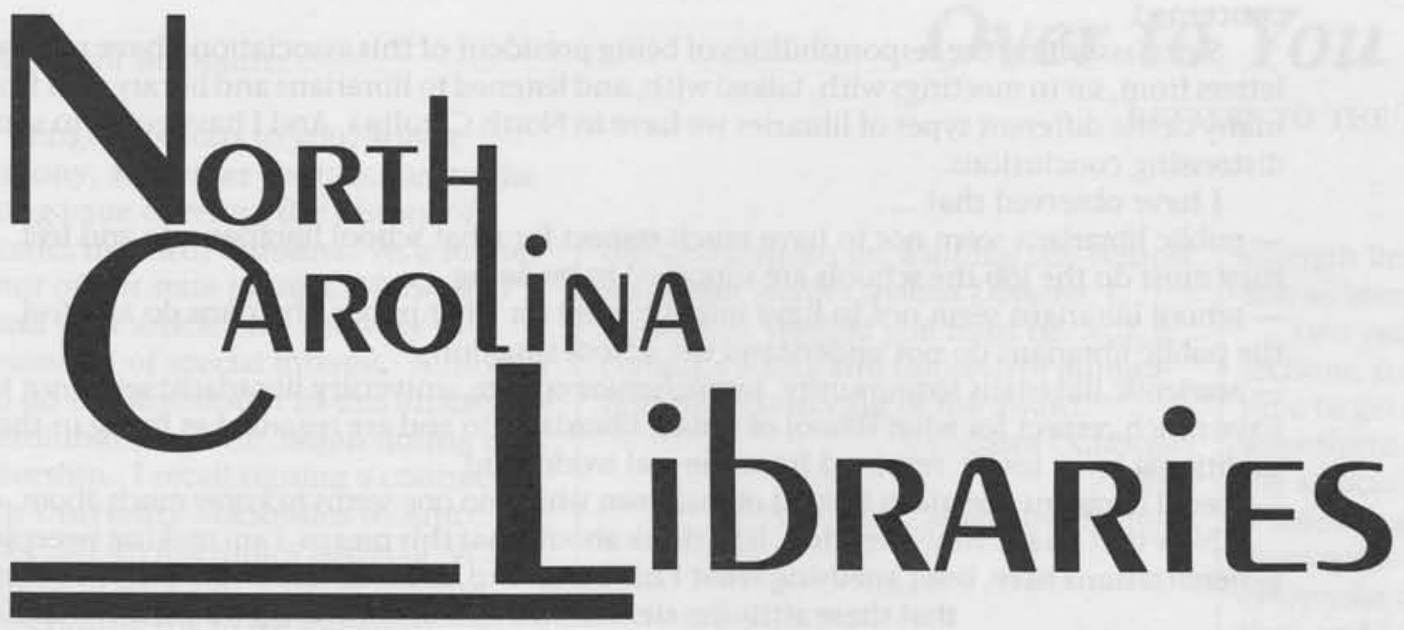

\section{Librarians and the Political Process}

69 Foreword, John Welch

71 Influencing the Legislative Process, Betsy L. Cochrane

73 Pushing Libraries: Yesterday and Tomorrow, Josephus Mavretic

76 Anatomy of a Bill, Howard F. McGinn

84 The Best of Times, The Worst of Times: The Politics of the Library Collection Katherine R. Cagle

87 The Political Environment of Libraries in The University of North Carolina, Benjamin F. Speller, Jr.

91 The Public Library's Political Agenda, Dale Gaddis

95 Faith, Hope, and Politics in Cumberland County, Jerry Thrasher

98 Getting Involved in the Political Process: A Selected Bibliography, John Welch

\section{FEATURES}

66 From the President

67 Over to You

100 \& In Edition: Cultural Oasis or Ethnic Ghetto?: The North Carolina Foreign Language Center and Statewide Multilingual Public Library Service, Plummer Alston Jones, Jr.

106 Point: Taking the Political Process on Its Own Terms: Hire a Lobbyist, Edward Sheary

107 Counter Point: Making an Issue of Library Support: Use the Ballot, Harry Tuchmayer

108 Library Research in North Carolina: North Carolina Library School Faculty Research, 1991: A Compilation, Robert Burgin

Advertisers: Book Wholesalers, 99 ; Broadfoot's, 97; Checkpoint, 109; Current Editions, 94; H. W. Wilson, 70; Ebsco, 3; Job Hotlines USA, 86; Mumford Books, 113; Phibig, 89; Quality Books, 75; Salem Press, 90; SIRS, front cover; Southeastern Book Co., 93; Southeastern Microfilm, 86; Thorndike Press, 115; UNC Press, back cover.
110 North Carolina Books

116 Lagniappe: Librarians in the Political Process: Selected Resources, Pat Langelier

120 NCLA Minutes

122 About the Authors

Cover: West façade of the old State Capitol in Raleigh. Photo courtesy of Division of Archives and History.

Norih Carolina Libraries is electronically produced. Art direction and design by Pat Weathersbee of TeamMedia, Greenville, NC. Special thanks to John Lance and Walker-Ross Printing Co., Inc., Rocky Mount, NC. 
When I last wrote to you, I spoke of being proud. Now I need to speak to you about being concerned.

Since assuming the responsibilities of being president of this association I have received letters from, sat in meetings with, talked with, and listened to librarians and library staff from many of the different types of libraries we have in North Carolina. And I have come to some distressing conclusions.

I have observed that ...

- public librarians seem not to have much respect for what school librarians do and feel they must do the job the schools are supposed to be doing,

- school librarians seem not to have much respect for what public librarians do and feel the public librarians do not understand the school situation,

- academic librarians (community, junior/senior college, university librarians) seem not to have much respect for what school or public librarians do and are regarded as living in the traditional ivory tower, removed from the real world, and

- special librarians operate in a world of their own which no one seems to know much about.

Now that I have your attention, let's think about what this means. I am making sweeping generalizations here, but I am using what I have heard to make an important point.I believe that these attitudes stem from a lack of knowledge and understanding of each other and the unique problems and demands each of us faces.

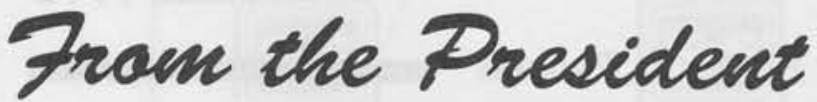

Janet Freeman, President We stereotype our colleagues and unfortunately sometimes act on those stereotypes.

At the May meeting of your Executive Board, I said these things. They were shocking, but what followed was an important, serious discussion about the role of librarians in today's society, the state of the association, and our responsibilities as leaders in the profession.

Board members spoke earnestly and passionately about the need for librarians and library personnel to assume more leadership in this information industry ... to be more outspoken on issues that effect their funding and to tell their funders what they need ... to become more savvy about working with the media to market themselves positively.

Some of our discussion was stimulated by Howard McGinn's article "The Mourning After" which appeared in the Winter 1991 issue of North Carolina Libraries. We agreed with many of the startling observations he made and disagreed strongly with others; however, we agreed that we were glad he wrote as he did and provoked us into thinking about issues we have not addressed.

We need to carry these conversations beyond this Executive Board meeting. I have asked the board members to communicate with you about these concerns. Respond to me or to them. Let us know what you think. Suggest ways to address the problems you see.

We are all a part of a fabric of information resources for our users. It is the responsibility of each of us to work together to make this a seamless fabric, each portion of the fabric no weaker than any other. The citizens of North Carolina should be able to move about on the fabric without stumbling over a seam or falling through a hole or a weaving flaw.

The users of libraries are the responsibility of us all. Each one of us provides a part on the information service continuum.

In Alamance County, the Friends of the Alamance County Public Libraries deliver to hospitals a 12-month size t-shirt bearing the message "Read to Me," a copy of Goodnight Moon, and a reading list for new parents. From then until that child enters school, his/her "information" needs are the responsibility of the public library. From kindergarten to 12 th grade his/her information needs before 3:00 p.m. are the responsibility of the school library and after 3:00 p.m., the public library. After high school graduation his/her information needs become the province of the higher education institution he/she chooses. After graduation he/she takes a job in an industry that provides a specialized library of technical resources.

But this library user has the right at any stage of life to obtain the information he/she needs. We as information professionals must work together to see that those resources are available, affordable, and accessible.

Ultimately, our users must be equipped to be life-long learners who can take advantage of all sources of information, whether they be at the public library, the academic library, the school library, or the special library.

We who work in these libraries need to talk to each other and learn from each other, so write about what you think and do. Submit your writing to North Carolina Libraries. The rest of us need to benefit from your creativity and you from ours. If library staff from all kinds of libraries in your area do not meet regularly, start a local library association. If one already exists, participate.

I am concerned, but I am also confident that together we can make a difference and provide the access to information to which our citizens have the right. This is a call to action. For too long we've segmented ourselves into categories ... school, public, academic and special. It is imperative that we now work together.

(to be continued) 
Congratulations to you, Robert Anthony, and other contributors to the Spring issue covering the history of libraries in North Carolina. As a former editor of our state journal (1965-68), I found your article "On the Way to Becoming" of special interest. Although you do not mention it in this article, the microfilming of $N C L$ began during my editorship. I recall signing a contract with University Microfilms in Ann Arbor, MI, to microfilm issues of $N C L$ beginning with Vol. 1, then mailing issues during the first 25 years of publication to UMI.

Charles Adams, then director of Jackson Library at UNC-Greensboro, was president of NCLA and he, together with members of the Executive Board, gave me virtually complete latitude in editorial decisions, a condition which made my job much easier than it would have been otherwise. NCL has shown marked improvement during the past 25 years. Given the dedication of future NCLA leaders and editors, I am confident it will retain its position as one of the leading state library journals in the nation.

PS: May I suggest that a forthcoming issue be devoted to church libraries, a type of library usually neglected in library literature.

Sincerely,

Alva Stewart Reference Librarian F.D. Bluford Library North Carolina Agricultural \& Technical State University Greensboro, NC 27411

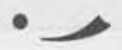

Dear Frances:

Congratulations! It was wonderful news in Janet Freeman's column that North Carolina Libraries has been recognized by the American Library Association as the 1991 H.W. Wilson Periodical Award.

You and your editorial team have done a wonderful job. I very much enjoyed my opportunity to work with you as a guest editor for the Spring 1991 issue.

Best wishes,

Timothy L. Coggins

Associate Director

\& Clinical Assistant Professor of Law Law Library

The University of North Carolina at Ch-H.
Congratulations on winning the Wilson Award for North Carolina Libraries. I know how thrilled you must be. $N C L$ is certainly a fine and impressive publication, well deserving of the award.

Carol Cubberley

Editor

Mississippi Libraries

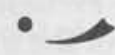

Dear Mr. Anthony:

On behalf of the Executive Mansion Fine Arts Committee and the Executive Mansion Fund, Inc., I want to thank you for including Rose Simon's review of the book North Carolina's Executive Mansion

...The First Hundred Years in the Winter 1991 issue of North Carolina Libraries.

I think Ms. Simon's review is the bestwritten one we have been privileged to have, and I am writing to thank her also.

With no budget for advertising the book, every time it is mentioned in a publication such as North Carolina Libraries, our sales get a boost.

Thank you again for helping to promote this new Executive Mansion centennial history book.

Yours sincerely,

Marie Sharpe Ham Curator \& Executive Director Executive Mansion Fund, Inc.

-

\section{Responses to Howard McGinn's "Point: The Mourning After" ...}

I read your "Point" essay, "The Mourning After," in the Winter 1991 issue of North Carolina Libraries, and I think you were wrong in at least two of your suggestions: 1) that NCLA should hold its conference every year; and 2) that NCLA should "control access to membership in the organization."

I left North Carolina for Virginia over two and a half years ago, and I am now in my second year on the Virginia Library Association Council. I have met many bright, energetic, thoughtful Virginia librarians, much like the ones I know in North Carolina. However, VLA, which has a conference every year, does not have the breadth of activity that NCLA does. This became apparent to me fairly soon after I arrived, but it took me a while to decide that much of NCLA's strength lies in its biennial conference, and its biennial terms of office.

Two years give NCLA's units sections, round tables, committees time to get organized to accomplish something. That's where the work of the association goes on, Howard, and where the association's strategies are developed. NCLA doesn't need an every-year conference to accomplish that, and I would argue that an everyyear conference would be a handicap.

An association that concentrates on annual conferences is likely to expend an inordinate amount of people's energy on that one event, to the detriment of grassroots activities - workshops, publications, committees - where the most important work of the association often occurs. Another of NCLA's strengths is its large school library membership in NCASL, which has the non-NCLA conference year available for its own biennial conference.

Biennial conferences in NCLA are financially solid, and proceeds are returned to the conference to ensure that. Biennial conferences also attract more exhibitors than annual conferences do, as we in North Carolina used to hear again and again from vendors, and as I have now witnessed first-hand from the other side of the border.

And in Virginia, an annual conference state, my one-year basic membership dues are the same as I pay for a twoyear membership in NCLA.

The second suggestion with which I strongly disagree is that NCLA should "control access to membership in the association .... If we do not respect our own credentials, how can we expect others to respect us as a distinct profession?"

Why a gratuitous slap at the nonMLS people who do two-thirds of the work in libraries, Howard? Is setting up artificial barriers between different levels of workers in libraries going to make us the powerful profession you envision? I think the opposite is true. Librarians become powerful as the libraries they work in become powerful institutions (as many already are). And libraries become powerful institutions only when library staffs work together as effectively as possible.

The thrust of management literature over the past decade or more has been on team-building. If we want to build effective (i.e., "powerful"?) organiza- 
tions, we are urged to flatten organizational structures, and to facilitate working together, recognizing the strengths that all members of the group contribute to the organization. Those of us who have graduated from schools of library science (or whatever they may be calling themselves these days) should have special knowledge and skills that we contribute to our libraries. If our performance doesn't illustrate the benefits of the degree, no amount of rhetoric at "professional" meetings or in library periodicals is going to make us powerful.

NCLA is the North Carolina Library Association. It exists "to promote libraries, and library and information services, and librarianship; and to champion intellectual freedom and literacy programs": (ARTICLE II. PURPOSE. Constitution of the North Carolina Library Association). NCLA has always been open to all library personnel, as well as to library supporters such as trustees, Friends, and vendors, and it has been energized by all of these groups. Perhaps there is strength to be gained from the fact that librarianship is not a traditional profession, with membership in its professional organizations limited to an "elite" group.

The fact that librarianship does not have the "power" that corresponds with things such as higher salaries has much more to do with librarianship's history as a female-intensive line of work than it does with the fact that we have democratic professional organizations. Let's make certain we know where the real enemy is, and attack that, rather than hamper the work of our comrades in arms with misguided "friendly" fire.

- Patsy Hansel, Director Williamsburg Regional Library Williamsburg, Virginia.

(President, NCLA, 1987-89)

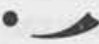

When I first started reading "The Mourning After," I found myself jumping ahead to read the punch line. At about the fourth paragraph, I realized that there wasn't going to be one.

The article had some good points and some correct facts. But in many instances, the wrong conclusions were drawn.

Since I am a paraprofessional and chair of the Paraprofessional

Roundtable, I would like to address the statement in the article that "access to membership in NCLA should be controlled." After working through the hurt and anger, I am left with a number of unanswered questions, the first being "who would be accepted for membership?" Was McGinn proposing an allMLS-holding organization? Would this mean the Trustees and Friends of the Library would be excluded? These people are some of the most politically influential people in libraries. What happens when they are excluded from membership? Or was McGinn proposing excluding only paraprofessionals?

The article speaks of NCLA concentrating in two areas - one being that of lobbying. When speaking of lobbying, numbers are clout. One thousand members is better than one hundred members. Just hów does NCLA gain lobbying power and clout by cutting back on its membership?

Where does the concept of teamwork fit into this picture? Does not "united we stand, divided we fall" apply to libraries as well as nations? Why set up artificial barriers in libraries - the "us against them" syndrome?

Over the past eighteen months, many states - through the leadership of ALA - have encouraged more participation by paraprofessionals through state associations. If North Carolina were to exclude paraprofessionals from the state library association, it would be like taking a step backward.

I believe, as do many librarians, that paraprofessionals should have opportunities for career development; should have a forum for discussing library-related issues; and should be encouraged to network with other library employees to talk about solutions for problems which occur in libraries. Where does the paraprofessional turn for these opportunities, encouragement, and forums if not to the state library association?
There are skills other than those of librarianship which are needed to achieve superior library service in North Carolina. Paraprofessionals are providing these skills and are helping libraries to remain open. Over half of a library's work force is paraprofessional. I cannot foresee a time when that work force will be one hundred percent MLS-holders.

To read an article that promotes excluding the paraprofessional from the state library association simply makes no sense at all. And I am very happy to report that obviously the leadership of the North Carolina Library Association agrees. At the Executive Board meeting of NCLA, held at Morehead City on May 1 , the Board unanimously agreed that paraprofessionals do have a place in the North Carolina Association and there are no intentions to exclude this important segment of the library workforce from membership in NCLA.

It will take all of us - the librarians and the paraprofessionals - to continue to give superior service to the citizens of North Carolina. We can only do it together - as a united workforce - not as a segregated workforce with "us" against "them." And I would encourage the state librarian to use the power and prestige of his office to promote this togetherness.

- Meralyn Meadows Administrative Assistant Stanly County Public Library

133 East Main Street Albemarle, NC 28001

\section{Apologia}

Editor's Note: Please note that the photographs on page 37 of the Spring issue of Noril Carolina Libraries are reversed. Pictured left is Nellie M. Rowe, Librarian at Greensboro Public Library; Pictured below is Mrs. Mollie Huston Lee, Librarian at Shaw University.

Norih Carolina Libraries invites your comments. Please address and sign with your name and position all correspondence to: Frances B. Bradburn, Editor, Norih Carolina Libraries, Joyner Library, East Carolina University, Greenville, NC 27858. We reserve the right to edit all letters for length and clarity. Deadline dates are the copy deadlines for the journal: February 10 May 10, August 10, and November 10.

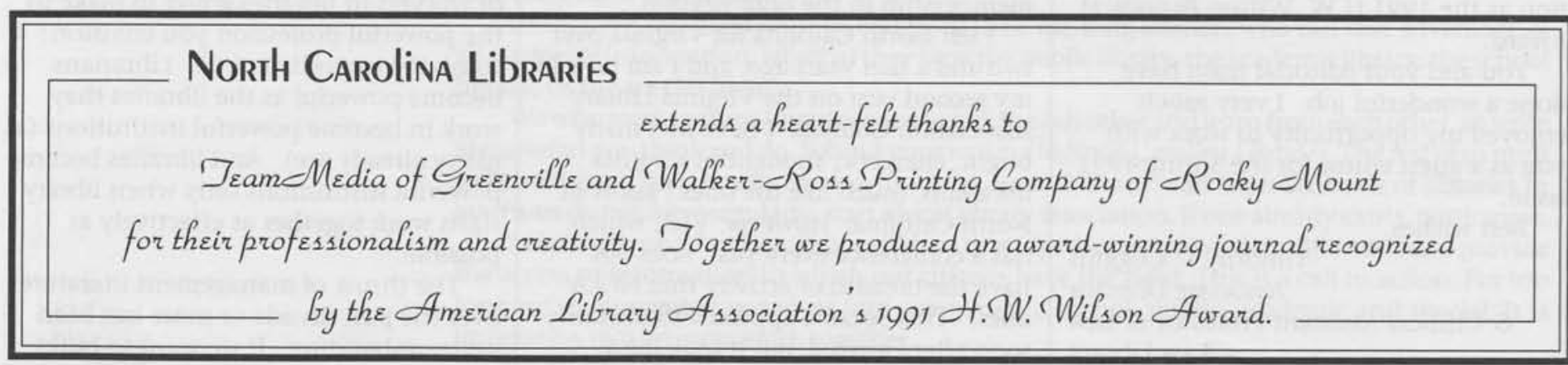


There could not be a more appropriate time to publish this issue of North Carolina Libraries with its focus on libraries and the political process. The high summer season of politics is upon us, and its residual heat will be felt through the November elections and far beyond. No matter where we turn, we are constantly reminded that politics does have a major impact on our daily professional lives. It directly affects our libraries whether they are in Burlington, Manteo, Murphy or Raleigh; whether they are in school, community college, public, or academic settings. And we ignore it or, worse, withdraw from it at our peril.

Many of us need to rethink our attitudes toward politics and the political process. Instead of being reactive to political events, we must challenge ourselves to become proactive at local, state, and national levels. If we do not take this opportunity to shape our profession's future direction, someone else will certainly do it for us. We must do it for ourselves!

Becoming active in the political process is not difficult. Once we understand how the political process works, we can articulate to politicians and to the general public the value of our services, and clearly state what goals we wish to achieve. With this foundation, we can confidently participate in any political arena.

One word of warning though! To be successful politically, we constantly must

Foreword ...

by John Welch, Guest Editor be aware of what is taking place in the public/political arena. Like ocean currents, politics (and politicians) are constantly changing and shifting - sometimes very dramatically, other times very subtly. We cannot make one political push a year and expect to be successful; we must be committed to thinking and working politically on a full-time basis. To paraphrase Thomas Jefferson, the price of successful politics is eternal vigilance.

The articles in this issue are designed to give the reader views of several different political arenas. As you read them, pay close attention to the interaction between the libraries and the political processes described. Note the ways in which situations are affected by politics and how libraries (and librarians) respond.

Your attention is drawn to two special articles by current members of the North Carolina General Assembly. Senator Betsy Cochrane offers her advice for effectively working with legislators on specific issues: know your objectives(s), have your supporting factual information ready, and marshall your forces. Representative Josephus Mavretic reminds librarians that to succeed politically, it is necessary to develop innovative strategies and to think big.

As a follow-up to those two articles, Howard McGinn writes a "diary" of the odyssey of a bill from its inception, through the legislative process to the point where it actually becomes written into the North Carolina General Statutes as a law. Note the appendices to Howard's article that show the various transformations of the legislation.

Jerry Thrasher presents us with an example of a political success story at the local level. The individual and collective efforts of the Friends of the Hope Mills Public Library prove again that citizens can and do have an impact on political decisions that affect library programs. Such natural alliances between libraries and their patrons strengthen the net results of political efforts for both parties. This article alone could be a manual for grassroots political action.

Dale Gaddis's article offers excellent examples of the types of political situations that libraries face on a recurring basis. Note particularly the library's assessment of the political settings that frame these examples and its response to them. Although the examples are specific to Durham County, they can readily be compared to similar situations throughout our state.

For a view of internal library politics at the state level, read Dr. Benjamin Speller's analysis of the state's university libraries. Dr. Speller offers an historical view of how politics changes over a period of time and how that change affects the policies and directions of individual academic libraries.

Kittye Cagle writes of the direct effect that local politics has on an individual collection. She reminds us that we must be continually examining and evaluating our collections in the context of ongoing political changes.

"Point/Counterpoint" debates the issue of whether NCLA needs to have its own lobbyist. Ed Sheary argues that we can no longer afford not to have professional help in promoting and tracking our legislative programs. Harry Tuchmayer, on the other hand, responds by saying that we should all be lobbyists and use our ballot box strength as a lobbying tool.

Finally, make certain that you read (and re-read) Patricia Langelier's "Lagniappe" column. What a wonderful compilation of political resources for librarians and patrons alike! Ms. Langelier assembled and annotated a variety of very important and useful information resources.

I wish to offer my thanks to all of the authors whose works are included in this issue. I greatly appreciate their time and effort, and I know that the readers of North Carolina Libraries will benefit from their work. Also, I want to say a special thank you to Nancy Bates, Director of the Davidson County Public Library, for her fine work and vision in outlining the articles, contacting prospective authors, and reviewing manuscripts for this issue.

As a way to focus the importance of the political process to all North Carolina librarians, begin your reading of this issue with Janet Freeman's presidential column. Janet has some very important things to say about NCLA, its internal political process, and the political roles that all of us can and should be playing for the improvement of our profession. 


\section{ALL THE OPTIONS FOR DATA DELIVERY}

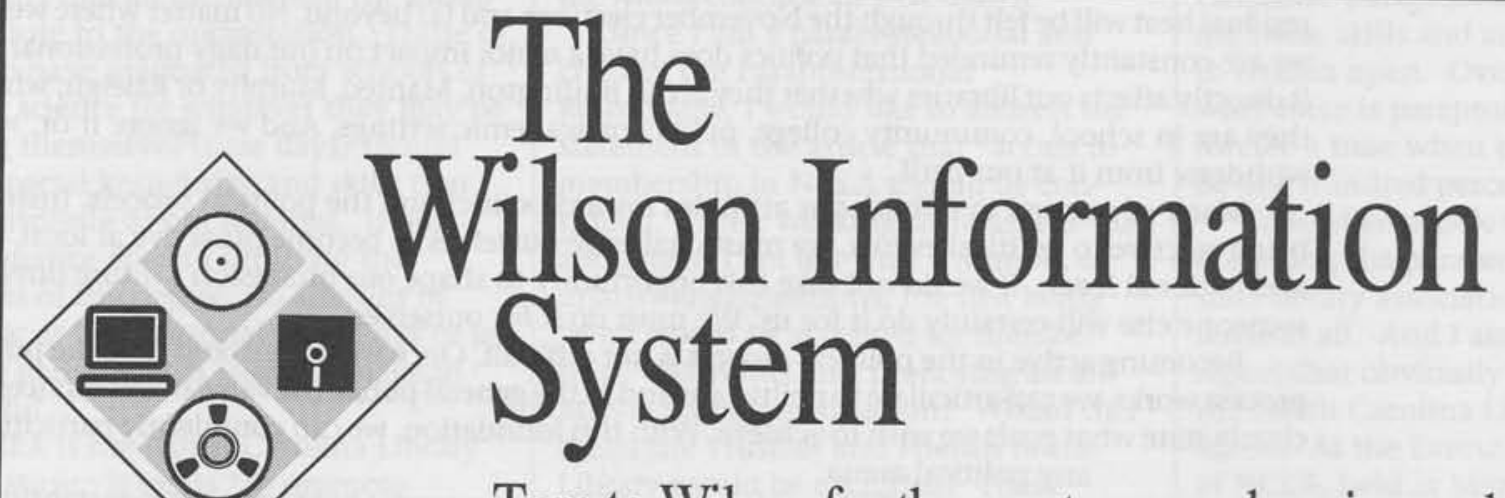

Turn to Wilson for the most comprehensive and affordable electronic retrieval system on the market-

DATABASES

AVAILABLE

Applied Science \& Technology

Index

Art Index

Bibliographic Index

Biography Index

$\checkmark$

Biological \& Agricultural Index

Book Review Digest

$$
\text { Business Periodicals Index }
$$

Cumulative Book Index

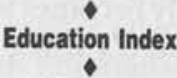

Essay and General Literature Index

General Science Index $\checkmark$

Humanities Index Index to Legal Periodicals

Library Literature

* LCMARC File $\checkmark$

* LC/Non-English MARC File

* MLA International

Bibliography Readers' Guide

Readers' Guide Abstracts Select Edition

Readers' Guide to Periodical Literature

* Religion Indexes

Social Sciences Index

Vertical File Index

Wilson Business Abstracts not produced by

Database not produced by
The H.W. Wison Company an integrated system of services unmatched in quality and ease of use by any other system.

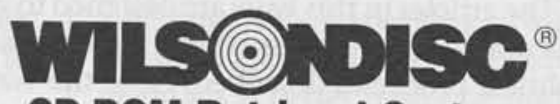

\section{CD-ROM Retrieval System}

Search each database on a separate compact disc, most of which are updated and cumulated monthly. Three search modes plus unlimited no-charge online searching make WILSONDISC the most user-friendly CD-ROM system available.

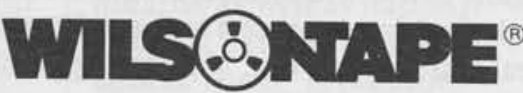

\section{Database Licensing Service}

Access data around the clock from homes, offices, and dormitories via machine-readable monthly tapes for each database. WILSONTAPE maximizes existing resources. Use the same hardware and software used for the public access catalog or other locally-loaded databases.

\section{WLOY}

\section{Online Retrieval System}

Online access with no start-up fee, no charge for saved searches, and no royalty charges added to connect-time rates make WILSONLINE the most economical search system available.

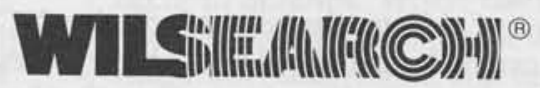

\section{Software for Direct Patron Access}

With menu-driven online access for patrons, WILSEARCH is ideal for every type of library. No prior search experience or training is required.

To order or for more information call toll-free 800-367-6770.

Outside of the U.S. and Canada call 212-588-8400. Telefax 212-590-1617. 


\title{
Influencing the Legislative Process
}

\author{
by Betsy L. Cochrane \\ Senator (23rd District), North Carolina General Assembly
}

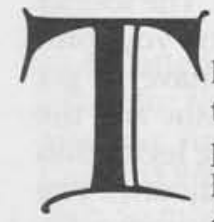

here are three kinds of people: those who make things happen, those who watch things happen, and those who wonder what is happening. Advocates for libraries want to be in the first group, making good things happen for libraries in North Carolina.Library advocates want to influenced state and local governmental entities so that library needs are among the priority items for elected officials.

As the special needs that are competing for the state tax pie increase, each slice of the pie gets smaller. This requires that advocates of the programs being funded do an even more thorough job of acquainting members of the General Assembly with the effectiveness of an individual program in meeting the needs of citizens.

Tax dollars must be used to address the most urgent needs of the people. The specific benefits of libraries to a given community become tools of influence when advocates vie for a slice of the tax pie or for policy changes in state statutes.

The first step in influencing state legislators, either for policy changes or funding, is to know the "players in the game," the ones you want to influence. Webster's Dictionary defines a politician as "one who is versed in the art and science of government; especially one who is actively engaged in the business of government." Many elected officials see themselves more as public servants, because public service is politics. Regardless of the perspective, you as a library advocate are interested in influencing the politicians elected to "engage in the business of government" in the General Assembly of North Carolina.

Begin by building rapport with your legislator. Know who represents you in the North Carolina Senate and North Carolina House of Representatives. Become familiar with the personalities with which you will be dealing and make personal contact with your legislators. Do this by an invitation to the library, a visit to their offices or other means of communication. Make sure they know who you are when you call or write. Knowing how the legislative system works would be beneficial and may prove interesting to you personally. I continue to be surprised at the number of citizens that do not even know that there are 50 senators and 120 representatives, let alone know what we do. Remember, legislators are regular people with a difficult task to perform as they represent their constituency. Be patient and cooperative as you try to develop this relationship.

Communicate with your legislators! We appreciate the information and the opinions of those most directly impacted by our decisions. Whether you communicate by letter or phone, be as specific as possible. Provide the bill number, the title, or the subject of the legislation, if possible. In the 106 legislative days of the 1991 Session, there were 2,280

bills introduced. With that many proposed pieces of legislation, you should understand why we may not immediately respond with the particular bill that causes you concern. Know your subject matter so you can influence with knowledge.

When you phone or write with specific identification of the legislation, indicate why you support or oppose the bill. Your reasons could be particularly helpful to a legislator's deliberations. In determining whether to support or oppose a bill, legislators may consider various factors. One immediate consideration is the bill's impact on the "folks back home" and the particular group the bill may be directed toward. Other questions to raise may be: how much will the proposal cost, has the money been appropriated, what alternatives could be considered, does this change in the law improve the situation or maintain the status quo, where can cuts be made, etc. A legislator's basic philosophi- cal beliefs guide the decision on a bill as profoundly as anything else.

If you have a special interest in a bill, stay informed on its progress. Bill Status is a support service of the General Assembly just for this purpose. The up-to-date status of legislation is available through 919/ 733-7779. This service can tell you if the bill is in committee, which committee, and if it is on the calendar for a vote. A bill must pass three votes in each chamber to become law, so you have several opportunities to influence the outcome.

Be accurate when dealing with legislators. It is also helpful to be brief. Reports or briefing papers are more likely to get immediate attention if they are concise. Bulky documents are put aside for when we have more time in our hectic schedules. Brief is better for immediate results.

It is important for you to make sure that legislators know what you are talking about when you communicate on an issue. You may need to educate your legislator regarding library programs or library issues, as well as assuring that terminology familiar to you is understood by your listener. Let your legislator know how a proposed bill will affect you or your programs. That is using your expertise to influence further in a beneficial way, and the information will be appreciated by your citizen legislator. We have to be "jacks-of-all-trades" in the Legislature, so we seek the help of experts, especially in our constituency.

Over time, you may wish to build a 
broad base of support for your issues. This could include local officials, community groups and library advocates - library trustees, advisory councils, etc., contacting legislators on your behalf. Local people can influence those for whom they can vote.

Be tolerant with your legislators. You may lose them on one vote or on one bill, but you may get their support on the next. If they support you eight out of ten times, the first group you want to favorably influence is the committee chairman and the members of the committee where the bill has been assigned. That committee is the first hurdle for the bill. It must pass the committee to have any chance, and this small group is the easiest place to stop a bad idea before it becomes law. Build your support or your opposition immediately for that small group of legislators, again using local library people who can influence their local legislator who serves on the committee.

If advocacy support is not legislators! We appreciate the information and the opinions of those most directly impacted by our decisions.... Know your subject matter so you can influence with knowledge.

surely you can consider that favorably. The point is that you keep asking for their support on your issues, be understanding when they may seem to support another view, and keep striving to educate them on your issues so that you lose them less often.

In the legislative process in Raleigh, half, nurture the bill through the process, and be alert for proposals that adversely affect your group. Lobbyists can be hired

byists can get your bills drafted and acquire sponsors for you also.

Lobbyists can contact committee members to influence them on your be- for the entire session or to work one piece of legislation. Some groups have a volunteer who performs the same service for free that lobbyists are paid to do. When there are few bills or issues with which to be concerned, a lobbyist may be more of an expense than a group can justify. A volunteer may be quite adequate in conjunction with local advocates. You must determine your needs and equate the cost.

When you have developed a good proposal, choose a champion for your cause, a legislator who believes in your issues. Your champion, because he/she is sold on the idea, can convince other legislators to believe in your issue. The sooner you start the wheels turning on your proposals, the longer you will have to get legislators educated on the issue and the better your chances of getting legislation approved before the session adjourns. You may need patience and perseverance, because some ideas take more than one session before they become law.

Before you begin lobbying your state senators or representatives, study the approaches that others have used to influence your decisions. The techniques that work best on you may prove helpful as you attempt to influence others, including legislators.

\section{EBSCO \\ is serials service (and more) for libraries.}

EBSCO believes in providing the best in serials service ... . and a lot more . . to our library customers. So we've designed our services and products with you, the librarian, in mind. Here are just a few of the many benefits EBSCO offers:

- Accurate, on-time order placement

- Comprehensive international serials service

- Customized serials management reports

- Invoice information in machine-readable form

- EBSCONET Online Subscription Service

- Interfacing with major automated library systems

- Unique CD-ROM reference products like: THE SERIALS DIRECTORY, MAGAZINE ARTICLE SUMMARIES, and the new ACADEMIC ABSTRACTS-created specifically for academic and large public libraries.

To learn more, contact us today. Let us show you what we mean when we say EBSCO is serials service fand more) for libraries.

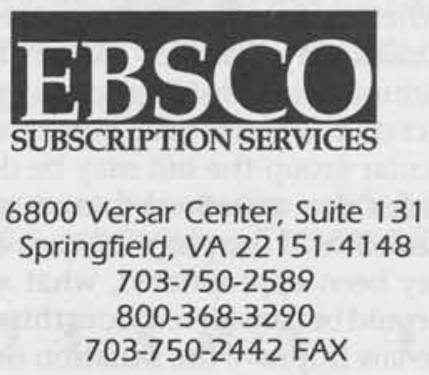




\title{
Pushing Libraries:
}

\section{Yesterday and Tomorrow}

\author{
by Josephus Mavretic \\ Representative (8th District), North Carolina General Assembly
}

How flattering it is to be asked to write an article for North Carolina Libraries a decade after my first presentation to the North Carolina Public Library Director's Association. So much has happened to our libraries in the decade of the 80 s and their future is so clouded, that this article provides me a unique opportunity to reflect upon excellence and ponder opportunities. The first part of this article is devoted to reminiscing about the spirit and energy that pervaded the North Carolina library establishment in the early $80 \mathrm{~s}$. The second is about a quiet period, and the third discusses possibilities for the first half of the 90 s. If there is a bias, it is that I believe in the concept of free and available libraries appropriate to the times.... look backward with me.

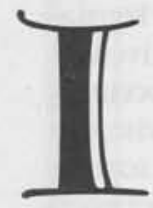

n 1981, during my first full term in office, Mary Jo Godwin was the Edgecombe County librarian and the president-elect of the newly formed North Carolina Public Library Director's Association. Throughout my campaign, she had helped me research issues that either cropped up during the campaign, or that I wanted to raise and address as a candidate. In addition to being very thorough and competent, Mary Jo was always friendly and courteous. Going to our library was a pleasure not only for me but for every other candidate who used Mary Jo as a resource. She treated every one of us the same fairly and without bias. Ms. Godwin never burned a political bridge because she knew that she might have to come home that way sometime. When she became the association's president in 1982, Mary Jo asked me to do a seminar on how to lobby legislators. That seminar was one part of a statewide effort called the "Three Million Dollar Push."

Every librarian had a vision about the local effects and the statewide result that the "Three Million Dollar Push" would have on North Carolina libraries. In librar- ies across the state there was excitement and energy. Librarians and their staffs held parties for legislators and Friends to build consensus for the "Three Million Dollar Push." The Secretary of Cultural Resources, Sara Hodgkins, publicly stated that libraries were the number one budget priority of that department. Senator Harold Hardison, chairman of the Senate Appropriations Committee, and Representative Al Adams, co-chairman of the House Appropriations Committee, had committed to the push. David McKay, the State Librarian, had gotten grudging agreement on a new formula for the allocation of state aid. Libraries had become a squeaky wheel thanks to grassroots political activity by librarians like Nancy Bates, John Jones, Nancy Massey and Bill Bridgman and the dedication of a few visionaries. The excitement overshadowed deep internal conflict, however, because the new formula diminished local political clout. Although there were last minute attempts to change the formula, none were successful. The three million dollars were included in the expansion budget for 198384 , and the rest is part of our library history. Today, less than half of the 1991 House of Representatives was in office when the three million dollar push occurred.

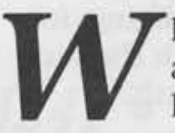

hen I reviewed my files for this article, I came across two lists of hints for lobbying legislators that need to be republished as we get ready for the library push of the 90 s. The first comes from the minutes of the NCPLDA meeting May 4-5, 1982 (editor's note: These comments were made by $\mathrm{Mr}$. Mavretic himself):

- Have a checklist on each legislator and get a commitment. Nail them to the wall if they press or if they change their votes.

- The squeaky wheel gets the oil, that's the American way. Letters do make a difference.
- Consensus is absolutely critical.

- Letters should be short, one page double spaced, all caps.

- When visiting legislators, keep your delegation small (one to three people). Be on time and leave early. Give time for legislators to react and write down thoughts. Don't try to be objective; that's the legislator's job. Be biased.

- Little things go a long way, especially photographic opportunities within the library.

- Most legislators view your product as "More and better books." You should stress that the libraries exist to provide service to the people. That is the key for legislators. PLDA should become the established authority on facts for North Carolina Public Libraries. Each

\section{Don't try to be objective; that's the legislator's job. Be biased.}

legislator should have a three ring binder on public libraries that is up-to-date and accurate. Your numbers must be creditable; they should be checked with the State Library and the legislative staff before distributing them to the legislature.

- Long range goals are needed and must be accepted in your policy statements. They should be used for growth and for cuts. The right question for a planner is, "What should I be doing in the next five to ten years?"

- A good strategy is to tell people where you will cut, and then cut it if you have to when you don't get funding. You gain creditability.

- Review your performance by determining if you did what you said you were going to. Tell your legislator how you used the money. 
- During 1981, librarians were their own worst enemies. Fight inside the family, but be united and present a solid front to the legislature. You either hang together or hang separately.

- With regard to the proposed State Aid Formula for public libraries, we had some questions about the income variable, but it is the best vehicle to date. Be sure you want this formula, because it usually takes six years to get it enacted. The library community needs to be unanimously enthusiastic in its support of any formula.

- A special supplementary money bill reflects weakness. It should be a part of the main budget package-continuation or expansion.

- Libraries are jumping through the hoop for peanuts.

- No formula will take the library community down the tube in the legislature.

-You need to have a plan, then go get the dollars to implement the plan.

- Get your funding through planning and through consensus.

The second list comes from the NCPLDA minutes of a meeting held August 19-20, 1982 (editor's note: These comments were made by Frederic J. Glazer):

- You've got to have an absolute solid front. If one legislator is not for it, they will split.

- You need enthusiasm to create visibility and universal acceptance of your proposal.

- Libraries have more people supporting them than other governmental agencies. Nobody opposes libraries and their funding. West Virginia State Librarian Fred Glazer calls it "Exploitation of confrontations."

- There is no known repellent to libraries. Most issues have pros and cons, but not the public library.

- Eleven thousand letters from Friends to the Governor will influence! There are no "Friends" for the sanitation and highway departments. Let your citizens express their needs to the legislators and how libraries have helped them.

- Conduct library appreciation days for legislators. Conduct letter writing campaigns thanking your legislators for their library support whether they gave any or not.

- Create opportunities for large crowds; take photographs, especially of legislators in the library and get them in the paper.

- Get a well-known personality such as Frank Gifford or George Plimpton to autograph books for legislators. Make it a non-adversarial confrontation.

- The best lobbyists are voters who are library users.

- The library is the only volunteer gov- ernment service that is a pleasurable experience to the public. We need to organize these users to support the library.

- Each year there is a new theme for the budget push in West Virginia; a three dollar check on titles and bookmarks, the library "Now" account, "Make a statement for state aid," ties and scarfs for legislators with the library theme, "The Library Pie Needs State Dough."

- Keep your themes and activities plain and simple.

- Libraries are not budget busters. Your legislators need to be stroked year round. There are basically two methods, "the scatter shot" and "the sniper method."

- You have got to have enthusiasm and excitement. You've got to believe.

- You've got a great product. There's nothing to be ashamed of. You should use Pentagon statistics for every circulation transaction. For every book checked out, you have at least 10 circulation transactions. You need to create your own measurement for the statistical people.

- Remind commissioners and legislators that the county budget is not their money. It's the people's money, and the people can change their minds on how it is allocated through pressure.

- West Virginia conducts a two week training program for librarians to keep them aware and conscious of local elected officials. They set up trust squads for missionary work. If the librarian doesn't listen or have a positive attitude, then the Trustees are alerted.

- Library appreciation day in West Virginia happens just before the state hearings on the library budget. There are good special speakers and special gimmicks to hand to all legislators.

- We need to work together to get the money we need. There's got to be a new day.

- Be organized! Get people out!

In addition to containing a lot of common sense, what's striking about these two lists - one from the State Librarian of West Virginia and the other from a North Carolina legislator - is the urging for consensus and the parallels with the successful "Three Million Dollar Push."

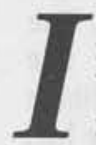
way toward the end of the decade as budget shortfalls, hiring freezes, and recession facts captured everyone's attention everyone, that is, except a few 90 s visionaries who, like their 80 s counterparts, know that the next squeaky wheel time for libraries is just around the corner. This time the debate will be more about electronics and attitudes than money. No one anticipated the electronic explosion of the $80 \mathrm{~s}$ and the effects it would have on library science, and no one expected to see the
costs of electronic transmission plummet as quickly as they did.

\section{... be united and present $a$ solid front to the legislature. You either hang together or hang separately.}

Legislators in general do not appreciate the upheaval that computers are causing in library science, and they do not understand the switching station role that libraries may play in the technological/service world of twenty-first century America. The notion that individual empowerment is directly dependent upon library configuration has yet to become part of our political lexicon. Substantive debate over the quality control of distance education is not on any legislative agenda. Debates about the relative values of books and networks do not occur in legislative study commissions. Likewise, the utilities commission has yet to start sorting through the boundary changes between communications, information, and enterainment.

My attitude about librarians is about the same after ten years. Mary Jo Godwin, President of NCPLDA in 1982, and Jackie Beach, President of the NCPLDA in 1992, both Directors of the Edgecombe County Memorial Library, are my personal librarians as I am their personal Representative. I go to Jackie Beach when I need information - just as I go to my hardware man when I want nails. I believe the information she helps me get, or gets for me, is accurate, and I rely upon it. I suspect that nearly everyone of my colleagues in the General Assembly feels the same about their local librarians, whether public, school, or academic. Beyond the hometown librarian, attitudes are not so clear. The fact that, as Howard McGinn states, "library schools are being closed, recruiting is stagnant, library budgets are being decimated, and libraries themselves are being absorbed...," tells me that elected 
officials do not have a basic commitment to libraries and librarians. Further, there seems to be increasing concern that the profession itself is at a definitional crossroad and unsure of its direction. The time seems right to begin the debate over the role of librarians in individual empowerment in twenty-first century democracy and the power of libraries in a technological society. Like most political debates, it needs to get started around something tangible with which legislators can identify, something simple so that the debate begins easily, and something expensive enough to get everybody's attention. My first thought is to debate transferring the CRAY- YMP supercomputer to the state library system in 1994 (when the next generation needs to come on-line at MCNC's supercomputing center). However, research shows that while the YMP is awesome at high speed computing, it is not designed to be the keystone of an integrated library system. Next, I talked with Doug Koontz and Julie Lahann at IBM about IBM-RS-6000s or IBM-AS-400s as the base for an integrated system. Those discussions led to a rough estimate of five million dollars a year for one-time, nonrecurring expenditures for hardware and software for each of the next five years. A maximum of a twenty-five million dollar capital appropriation would enable North
Carolina to become the national leader in library evolution. The target amount is big enough to attract attention; the hardware and software is tangible; and, to politicians, the goal appears straightforward. For librarians, however, the real issue is the additional cost of a transition to mass acquisitions and processing.

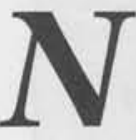
ow the question is, "How do we begin?" It seems to me that our State Librarian, Howard McGinn, has laid that out very well in his six points in the Winter 1991 edition of North Carolina Libraries.

1 . Hold the state conference every year.

2. Reorganize NCLA in order to deal with issues that face the entire profession.

3. Elect NCLA presidents on leadership rather than a rotation.

4. Put substance and purpose in NCLA meetings.

5. Hold the NCLA conference in conjunction with non-library associations.

6. Limit membership to NCLA to professional librarians.

What the association chooses to do relative to Howard's six points may very well hinge on the debate over six other issues: 1 . The need for dependable budgets that enable every library user to have access to the enormous amount of available information and that define the missions assigned to libraries.

2. The responsibility of public schools, community colleges, and the university system for teaching computer and information literacy.

3. The balance between books and electronic inventory, and a commitment to a standard of over 2 books per capita.

4. The return on taxpayer investment in public information assets and the related marketing plans for public information services and products that compete with commercial providers.

5. The relationship between electronic highways and technology libraries and the relationship of electronic highways to traditional infrastructure.

6 . The need for a comprehensive information policy that provides access, yet respects confidentiality, and a resolution of the copyright dilemma.

Even the most superficial response to these six issues and Howard's six points should be the notion that the relationships between librarians, libraries, and the tax paying public is under increasing tension, and that energetic activity is required... at the 1992 North Carolina Association Annual Conference.

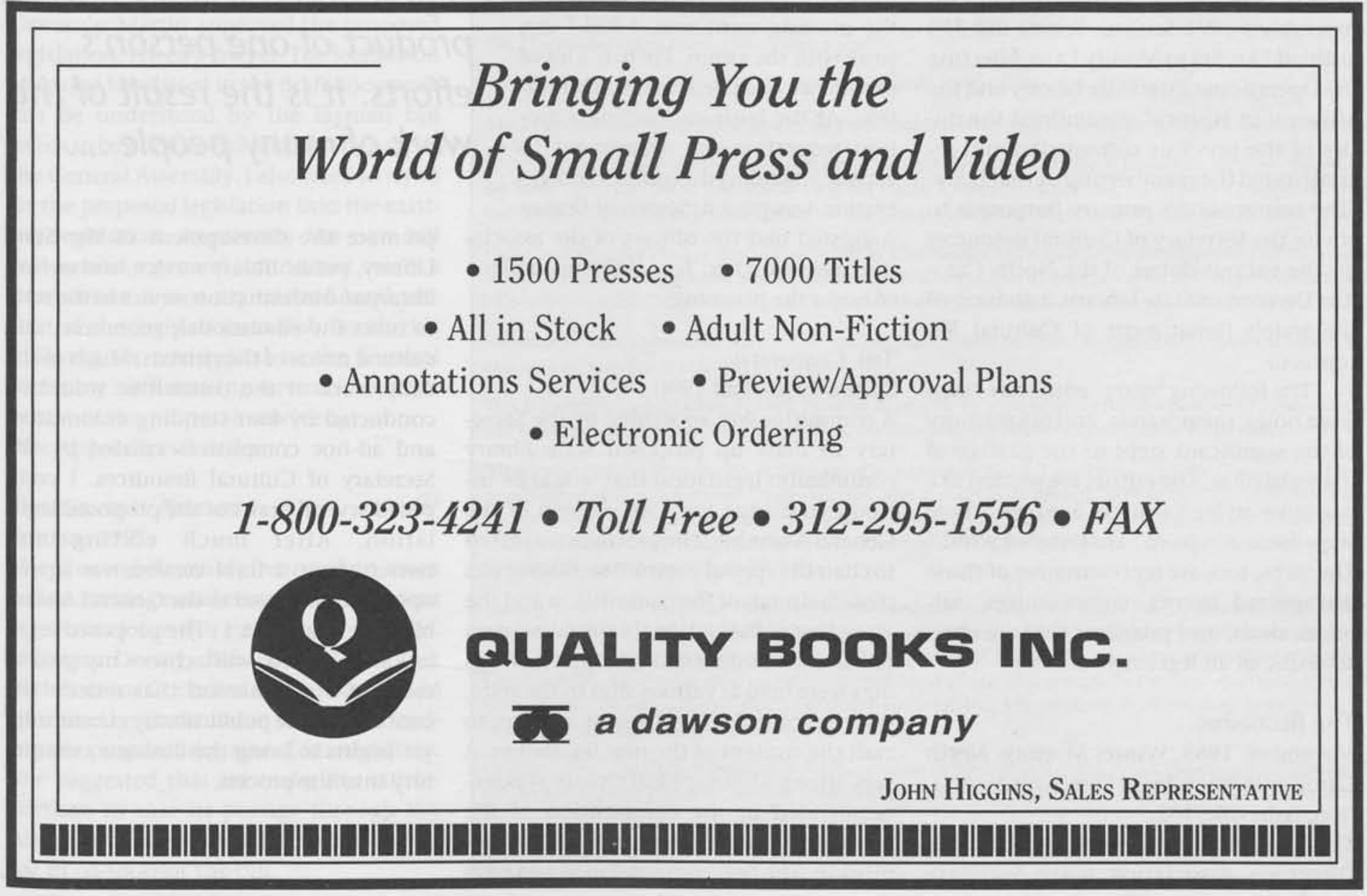




\title{
Anatomy of a Bill
}

\author{
by Howard F. McGinn
}

I

$\mathrm{n}$ a democratic society the legislative process is rarely orderly. It is, most often, chaotic, convoluted, and confusing, replete with unexpected events. Legislation is usually not the product of one person's efforts. It is the result of the work of many people, people sometimes at odds with each other, sometimes working in coalitions, people always forced to compromise in order to effect the passage of legislation. In 1988 I began the coordination of a process that eventually resulted in the enactment of new legislation affecting the North Carolina State Library Commission during the North Carolina General Assembly's 1991 Session. Senate Bill 350 entitled "An Act to Modify Laws Affecting the Operations of the State Library and the Museum of History" streamlined the duties of the previous commission and reconstituted the membership of that body. (The commission's primary purpose is to advise the Secretary of Cultural Resources on the various duties of the North Carolina Division of State Library, a division of the state's Department of Cultural Resources.)

The following "diary" entries are taken from notes, memoranda, and my memory of the significant steps in the passage of the legislation. The entries are written in a narrative style. Taken as a whole, these steps form a type of "anatomy of a bill." The steps, too, are representative of those unexpected events, compromises, surprises, deals, and problems that are characteristic of all legislative activity.

\section{The BegrnNing.}

November, 1989. Winter Meeting. North Carolina Public Library Director's Association, Asheville, NC.

This was my first meeting with the Director's Association since Secretary
Dorsey (Secretary of Cultural Resources Patric Dorsey) announced that I would succeed Jane Williams as State Librarian in April. The Director's Association is very concerned about the small number of public library directors on the state library commission. This concern is legitimate, since the State Library directly affects many operations of local public libraries and distributes state and federal aid to these libraries. I feel we need to revise the commission legislation. It is over ten years old and is outdated. The information age has long since arrived and the current commission legislation is becoming irrelevant. Despite my apprehension, the meeting went well. I feel I can work with the group. There is a lot of experience and talent in the organization. At the business meeting a motion requesting the department to exploreamending the commission legislation was passed. Secretary Dorsey suggested that the officers of the association meet with her, Jane Williams, and me to begin the planning.

\section{THe COMmittee.}

Spring 1990 - Fall 1990.

A committee was appointed by the Secretary to draw up proposed state library commission legislation that would be introduced during the 1991 session of the General Assembly. Elinor Swaim was asked to chair the special committee. (Elinor was past-chairman of the commission and the vice-chair of the National Commission on Libraries and Information Sciences). Meetings were held at various sites in the state, once a month for nearly eight months, to craft the content of the new legislation. A very strong philosophical change was recommended in the composition of the membership and operations of the commission. The new commission would have members drawn primarily from the public library and the business communities. The number of gubernatorial appointees would be increased. The Lieutenant Governor and the Speaker of the House would each be given one appointment. Only the president and president-elect of the North Carolina Library Association would represent that organization. Three members would be named by the North Carolina Public Library Director's Association. The new commission's main duties would be to

\section{Legislation is usually not the product of one person's efforts. It is the result of the work of many people ....}

promote the development of the State Library, public library service, and overall library and information service in the state to meet the educational, economic, and cultural needs of the citizens. Much of the daily work of the committee would be conducted by four standing committees and ad-hoc committees created by the Secretary of Cultural Resources. I composed several drafts of the proposed legislation. After much editing and horsetrading, a final version was agreed upon and proposed to the General Assembly. (See Appendix 1) The proposed legislation, if passed, will achieve my goal of creating a commission that reflects the concerns of the public library community yet begins to bring the business community into the process. 


\section{APPENDIX 1}

\section{North Carolina Department of Cultural Resources}

Getting the Bill Passed.

Fall 1990.

I spoke with Deputy Secretary of Cultural Resources Robert Booth about the proposed legislation. Because the Department of Cultural Resources is a cabinet level agency, its legislative package needs to be approved by the Governor's Office. I anticipate no difficulty in getting Governor Martin's approval. He has been very supportive of State Library programs. Bob Booth and I discussed which legislator we wanted to ask to sponsor the legislation and steer the project through the General Assembly. We both thought that Senator Betsy Cochrane ( $\mathrm{R}$ - Davie) would be an excellent choice. She is a strong supporter of her local public library in Mocksville and was instrumental in helping the Davie County Public Library acquire the county funding needed to match the federal LSCA Construction grant it had received for an expansion of the facility. She has also helped public library development in other counties in her district, especially Davidson County.

\section{LegisLative LANGUAGe.}

November 1990.

Governor Martin approved the proposed legislation. I need a lawyer. The legislation language I had used in the draft document can be understood by the layman but needs to be put into the arcane language of the General Assembly. I also need to try to tie the proposed legislation into the existing legislation. Apparently the new bill will amend a general statute, not create a new statute. I sent my laicized legal version of the legislation to Bob Booth this morning for transmittal to the General Assembly's bill drafting service. I hope the intent of the proposal survives.

(See Appendices $2 \& 3$.)

\section{The General Assembly.}

January 1991.

The General Assembly returned to town today. Parking now becomes non-existant for visitors for the next eight months. Secretary Dorsey, Bob Booth and I met with Senator Cochrane to ask if she would sponsor the commission bill. After reading the proposal she agreed immediately. She suggested that we make the bill bipartisan to ease its passage through the Assembly. She will ask a Democratic Senator to co-sponsor the bill.
109 East Jones Street

Raleigh, North Carolina 27601-2807

Telefacsimile: $919-733-8748$

James G. Martin, Governor

Patric Dorsey, Secretary

Division of State Library

Howard F. McGinn, State Librarian

143B-90. STATELIBRARY COMMISSION; CREATION, POWERS AND DUTIES. There is hereby created the State Library Commission of the Department of Cultural Resources. The State Library Commission has the following functions and duties:

(1) To advise the Secretary of Cultural Resources on matters relating to the operation and services of the State Library.

(2) To work for the financial support of statewide and local public library services.

(3) To work for the financial support of statewide interlibrary services.

(4) To aid and advise the Secretary in the development and distribution of information services for the promotion of cultural, educational and economic well-being.

(5) To aid and advise the Secretary on the recruitment and appointment of the State Librarian.

(6) To advise the Secretary upon any matter the Secretary might refer to it.

143B-91. STATE LIBRARY COMMISSION; MEMBERS; SELECTION; QUORUM; COMPENSATION; COMMITTEES: MEETINGS; EXPENSES.

The State Library Commission shall consist of fifteen members. Eight members shall be appointed by the Governor with an interest in library and information services in North Carolina. One member shall be appointed by the Lt. Governor. One member shall be appointed by the Speaker of North Carolina House of Representatives. Three members shall be appointed by the North Carolina Public Library Director's Association. Two members shall be the President and President-elect of the North Carolina Library Association or two appointees as determined by the North Carolina Library Association Board of Directors. The State Librarian shall be an ex-officio member and act as secretary to the Commission.

All appointments shall be for four year terms with eight of the commissioners taking office on one four year cycle and seven commissioners taking office on the second four year cycle.

Any appointments to fill a vacancy in one of the positions appointed by the Governor, Lt. Governor or Speaker of the House shall be for the remainder of the unexpired term. Appointees shall not serve more than two successive four-year terms.

The Governor shall choose a Chairperson from among the gubernatorial appointees. The chairperson shall not serve more than two successive two-year terms as chair.

The Commission shall meet at least twice a year.

A majority of the Commission shall constitute a quorum for the transaction of business.

All clerical and other services required by the Commission shall be supplied by the Secretary of Cultural Resources.

There shall be standing committees established to advise the Secretary of Cultural Resources, the Commission, and the State Librarian. These committees shall be: Public Library Development; Interlibrary Cooperation; State Government Information Services: State Library Development; and any other committee deemed appropriate.

Each Committee shall be composed of a Committee Chairperson and at least six persons appointed annually by the Secretary of Cultural Resources with the approval of the Commission. At least one of the Committee members shall be a member of the Commission. Each Committee shall report to the Commission at least once a year.

Members of the Commission and the Committees shall receive per diem and necessary travel and subsistence expenses as provided in G.S. 138-5.

This bill shall be effective July 1, 1991. In order to provide for a transition to the new number of commissioners and assure the necessary rotation of members, the following appointment cycle shall be established:

All members of the Commission at the time of enactment of this bill shall remain on the Commission for the remainder of their terms except Commissioners who are members through election as Chair of the following Sections of the North Carolina Library Association: Public Library Section; College and University Section; Junior College Section; and President of the North Carolina Association of School Libraries. The terms of these Commissioners will expire June 30, 1991.

On July 1, 1991, the Governor shall appoint four persons to full four year terms. The Lt. Governor shall appoint one person to a two year term; The Speaker of the House shall appoint one person to a two year term; two appointees of the North Carolina Public Library Director's Association shall begin a two year term; one appointee of the North Carolina Public Library Director's Association shall begin a full four year term; the President-elect or an appointee of the North Carolina Library Association shall begin a full four year term; the President or an appointee of the North Carolina Association shall begin a two year term.

On July 1, 1993, the Governor shall appoint four persons to full four year terms; the Lt. Governor shall appoint one person to a full four year term; and the Speaker of the House shall appoint one person to a full four year term.

Draft $10 / 12 / 90$ 


\section{The General Assembly.}

March 1991.

The General Assembly's version of the commission bill language was released today and promptly introduced by Senator Cochrane. She had three very influential Democratic co-sponsors of the legislation: Senator Frank Block (D-New Hanover), Senator Richard Condor, (DRichmond) and Senator Mary Seymour (D-Guilford). My original proposal has been split into two bills by the drafting service in order to amend all appropriate general statutes. The new bills are numbered Senate 353 and Senate 354 . They have been referred to the Senate Travel, Tourism and Cultural Resources Committee for hearings. (See Appendices $4 \& 5$ )

The General Assembly.

Senate Travel, Tourism, and Cultural
Resources Committee.

April 1991.

It took several days to get the bills on the committee's calendar, obtain a quorum to conduct business, and obtain approval, but we made it. Senator Cochrane, Secretary Dorsey, Nancy Bates, Director of the Davidson County Public Library, and I testified on behalf of the bills. There was some concern expressed by the committee about the increase in gubernatorial appointees, but the provision granting the General Assembly two appointees for the first time eased concerns. The bills will now be sent to the floor of the Senate for the required three readings and Senate passage.

\section{The General Assembly.}

April 1991.

The Senate passed the bills without change.

\section{APPENDIX 2}

\section{North Carolina Department of Cultural Resources}

109 East Jones Street

Raleigh, North Carolina 27611

Telefacsimile: 919-733-5679

James G. Martin, Governor

Patric Dorsey, Secretary

November 20, 1990

MEMORANDUM

TO: BOB BOOTH

FROM: HOWARD MCGINN

STATE LIBRARIAN

SUBJECT: DRAFT AMENDMENT TO: G.S. 143B-90

\section{A BILL TO BE ENTITLED \\ AN ACT TO REVISE THE DUTIES OF THE MEMBERS \\ OF THE STATE LIBRARY COMMISSION}

The General Assembly of North Carolina enacts:

Section 1. G.S, 143B-90 is amended as follows:

1) In the first paragraph by rewriting the second sentence to read:

" To work for the financial support of statewide and local public library services."

2) In the first paragraph by rewriting the fourth sentence to read:

" To work for the financial support of statewide interlibrary services."

3) In the first paragraph by rewriting the fifth sentence to read:

" To aid and advise the Secretary of Cultural Resources in the development of information services for the promotion of cultural, educational, and economic well-being."

4) In the first paragraph, the sixth sentence is deleted.

5) In the first paragraph, the seventh sentence is deleted.

6) In the first paragraph by rewriting the eighth sentence to read:

" To aid and advise the Secretary of Cultural Resources on the recruitment and appointment of the State Librarian."

Section 2. This act shall become effective July 1, 1991.

\section{JUSTIFICATION FOR AMENDMENTS TO G.S. 143B-90 AND G.S.. 143B-91}

The rapid development of statewide, national, and international electronic services of information and the significant changes in library services, especially Public Library Services, in North Carolina have necessitated changes in the statutes defining the composition and duties of the State Library Commission. As Public Libraries, in particular, expand their services to business and education, as the State Library expands their services to State Government and businesses, as the North Carolina Information Network continues to develop, the role and nature of the membership of the Commission needs to change to meet the needs of an information-based economy and society. The recommended changes to existing legislation will help meet these needs for the future by providing more citizen input into the development of statewide library and information services.
This legislation seems to be on a fast track. It has been sent to the House of Representatives for House Hearings and passage. I hope we get the new legislation passed in time for the appointments to become effective at the beginning of July.

\section{The General Assembly.}

May 1991.

My secretary, Connie Bryant, has been checking with the General Assembly's bill status office and Senator Cochrane every few days to try to learn how the bills are progressing in the House. No action. The fast track is slowing. The state's budget problems are overshadowing all other matters.

\section{The General Assembly.}

June 1991.

Still no action in the House. Budget problems are becoming more severe. I am becoming anxious. Senator Cochrane tells me not to worry.

\section{The General Assembly.}

July 9, 1991.

Senator Cochrane called and said that the bills may be heard by the House subcommittee tomorrow. She asked if I would attend in case testimony was needed. The General Assembly is anxious to go home. Time is getting short. If the bill is not passed during this session we will not be able to cycle in the new appointment structure until the summer of 1993 (assuming that it is passed in the short session or resubmitted in the next General Assembly).

\section{The General Assembly.}

July 9, 1992.

Strange day. When the bill was called for its pro-forma hearing by the House, it had been combined with four other bills affecting the Department of Cultural Resources, renumbered as Senate Bill 350 . (See Appendix 6) It will be considered as a committee substitute. It is now a catch-all bill that includes the commission legislation, legislation designating the State Librarian as the overseer of the state's publications style manuals, provisions to permit the Department of Cultural Resources to operate a hamburger stand in the new Museum of History, and a paragraph that requires the Museum of History to maintain the records on artifacts in the Executive Mansion and old State Capitol building. Senator Cochrane and the members who are sponsoring the other legislation 
that has been rolled into the commission legislation asked for a postponement of the vote until tomorrow. I asked the Senator what had happened. She said that part of the problem was the rush to adjourn; part was parliamentary procedure. I didn't press the matter.

The General Assembly.

July 10, 1992.

The new all-purpose bill, Senate 350 , was reported favorably out of the House Committee today. It will be sent to the floor of the House for a vote tomorrow. There is one small technicality that may destroy the whole effort. Because this is now considered to be a new bill, it has to be sent back to the Senate for concurrence if passed by the House. Adjournment could occur at any time.

\section{The General Assembly.}

July $11,1992$.

The House passed the bill. Passage requires three readings on the floors of the House and Senate. The bill has now been sent to the Senate for concurrence.

\section{The General Assembly.}

July 16, 1992.

Senate 350 was passed today. We have new commission legislation. The Department also has permission to operate a hamburger stand, designate style manuals, and record the purchase of antiques stored in the mansion. I wrote and called Senator Cochrane to offer my congratulations and appreciation for her work. She sounded weary. The General Assembly will probably adjourn tomorrow.

The events that led to the passage of Senate 350 were not unusual. While the process is tedious, it is important to note that private citizens can recommend legislation and aid legislators in the passage of legislation. The democratic process at the state level can be used by non-legislators if the issue requiring study and legislation is of interest to a sufficient number of legislators, is positive, has community support, will solve existing problems or create beneficial new programs, and, especially, if the appropriation of tax dollars is not involved. Legislation need not be "landmark" to be important. Senate 350 did not result in endless debate by the media, did not produce demonstrations outside of the Legislature, did not polarize citizens. Yet, when fully in force, it may revolutionize library service in the state.

\section{APPENDIX 3}

\section{North Carolina Department of Cultural Resources}

109 East Jones Street

Raleigh, North Carolina 27601-2807

Telefacsimile: 919-733-8748

James G. Martin, Governor

Patric Dorsey, Secretary

Division of State Library

Howard F. McGinn, State Librarian

November 20, 1990

MEMORANDUM

TO: BOB BOOTH

FROM: HOWARD MCGINN

STATE LIBRARIAN

SUBJECT: DRAFT AMENDMENT TO G.S. 143B-91

\section{A BILL TO BE ENTITLED \\ STATE LIBRARY COMMISSION - MEMBERS; APPOINTMENT; QUORUM; COMMITTEES; COMPENSATION.}

The General Assembly of North Carolina enacts:

Section 1: G.S. 143B-91 is amended as follows:

1) The first paragraph shall be rewritten to read:

" The State Library Commission shall consist of fifteen members. All members shall have an interest in the development of library and information services in North Carolina. Eight members shall be appointed by the Governor. One member shall be appointed by the Lt. Governor. One member shall be appointed by the Speaker of the North Carolina House of Representatives. Three members shall be appointed by the North Carolina Public Library Directors Association. Two members shall be the President and Presidentelect of the North Carolina Library Association or two appointees as determined by the North Carolina Library Association's Board of Directors. The State Librarian shall be an ex-officio member and act as secretary to the Commission."

2) The second paragraph shall be rewritten to read:

- All appointments shall be for four year terms with eight of the commissioners taking office on one four year cycle and seven commissioners taking office on the second four year cycle. Any appointment to fill a vacancy in one of the positions appointed by the Governor. Lt. Governor, or Speaker of the House shall be for the remainder of the unexpired term. Appointees shall not serve more than two successive fouryear terms."

3) The third paragraph shall be rewritten to read:

" The Governor shall choose a chairperson from among the gubernatorial appointees. The chairperson shall not serve more than two successive two-year terms as chair."

4) There is added a seventh paragraph to read:

The Commission shall meet at least twice a year."

5) There is added an eighth paragraph to read:

" There shall be standing committees established to advise the Secretary of Cultural Resources, the Commission, and the State Librarian. These committees shall be: Public Library Development; Interlibrary Cooperation; State Government Information Services; State Library Development; and any other committee deemed appropriate. Each committee shall be composed of a committee chairperson and at least six persons appointed annually by the Secretary of Cultural Resources with the approval of the commission. At least one of the committee members shall be a member of the commission. Each committee shall report to the commission at least once a year."

6) There is added a ninth paragraph to read:

* In order to provide for a transition to the new number of commissioners and assure the necessary rotation of members, the following appointment cycle shall be established:

(1) All members of the State Library Commission at the time of the enactment of this bill shall remain on the Commission for the remainder of their terms except Commissioners who are members through election as President of the North Carolina Library Association and Chair of the following sections of the North Carolina Library Association: Public Library Section, College and University Section, Junior College Section, and President of the North Carolina Association of School Librarians. The terms of these Commissioners shall expire June 30, 1991.

(2) On July 1, 1991, the Governor shall appoint two persons to full four year terms and two persons to two year terms. The Lt. Governor shall appoint one person one a full four year term. The Speaker of the House shall appoint one person to a full four year term. Two appointees of the North Carolina Public Library Directors Association shall begin a two year term. One appointee of the North Carolina Public Library Directors Association shall begin a full four year term. The President and Vice-President of the North Carolina Library Association or two appointees of the North Carolina Library Association shall begin a two year term.

(3) On July 1, 1993, the Governor shall appoint four persons to full four year terms. Two appointees of the North Carolina Library Public Library Directors Association shall begin full four year terms. The President and Vice-President or two appointees of the North Carolina Library Association shall begin full four year terms.

Section 2. This act shall become effective July 1, 1991. 

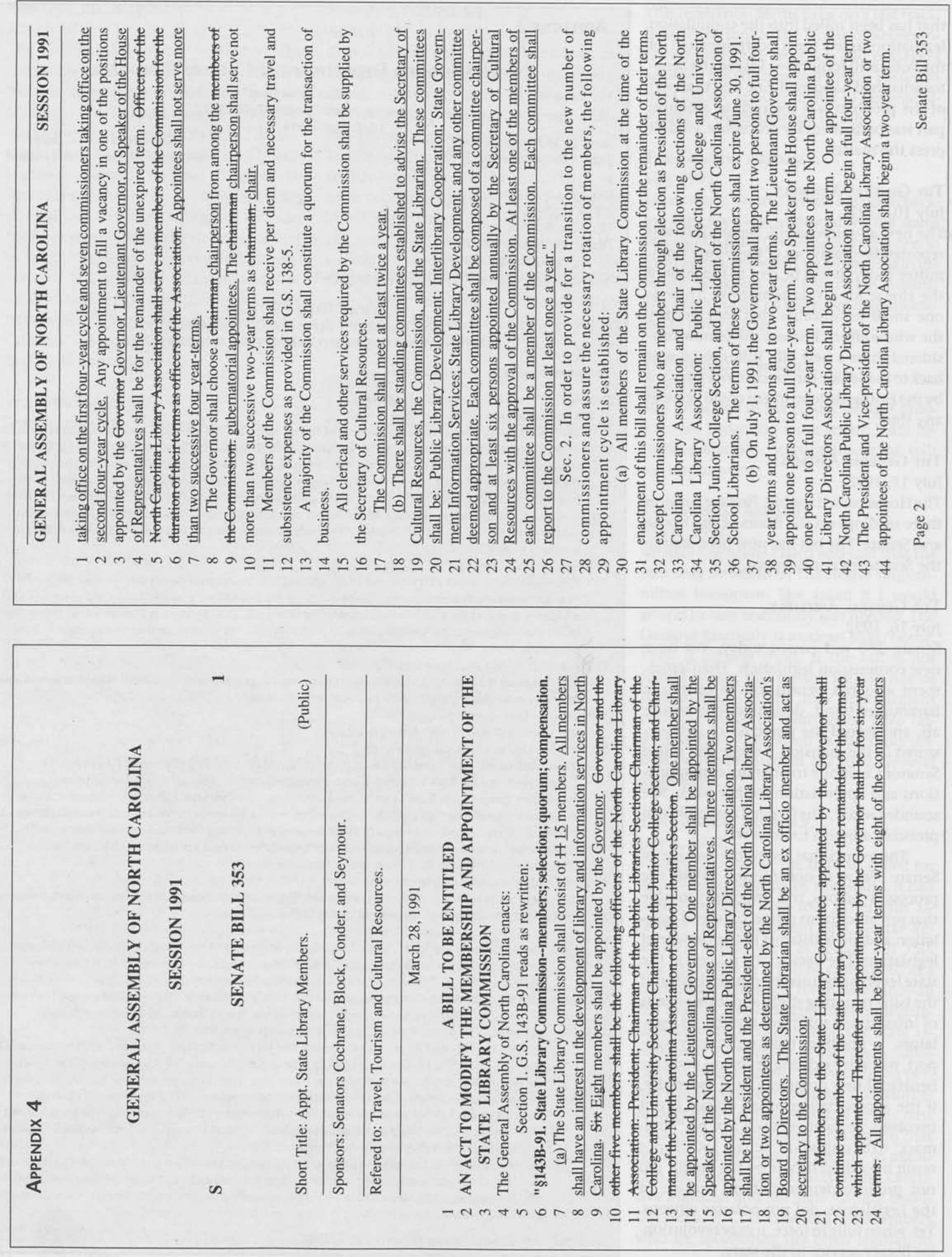
APPENDIX 4. (continued)

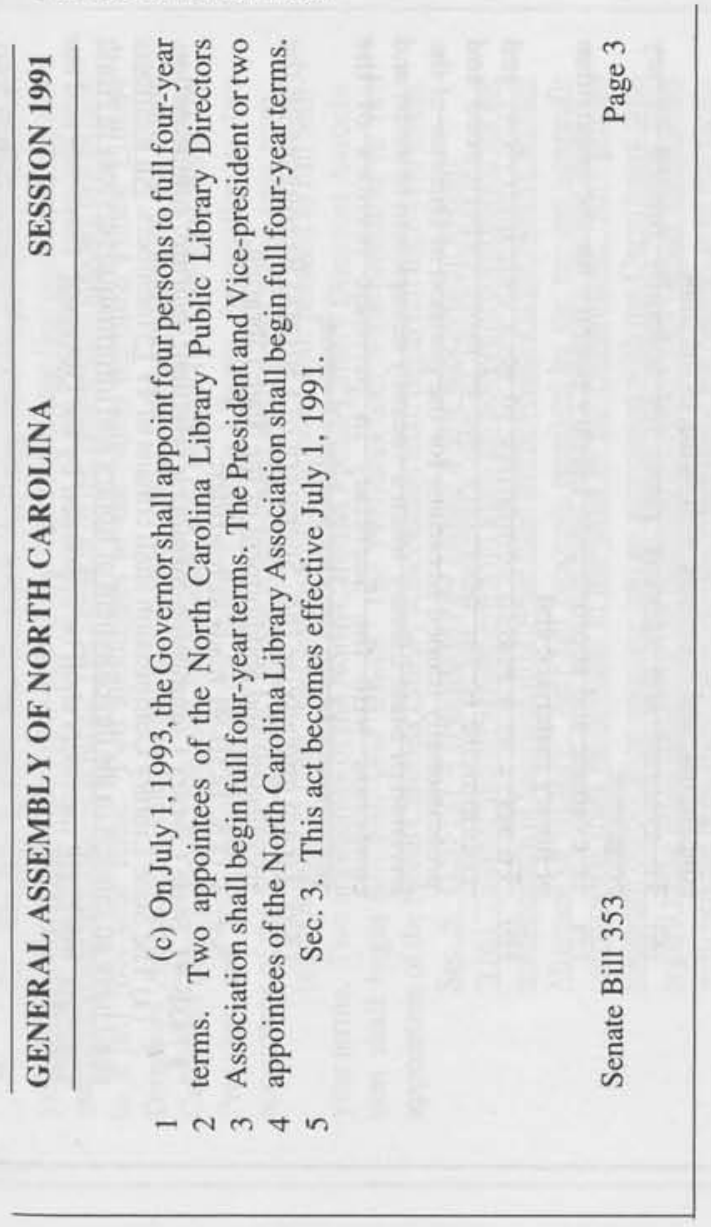

APPENDIX 5. (continued)

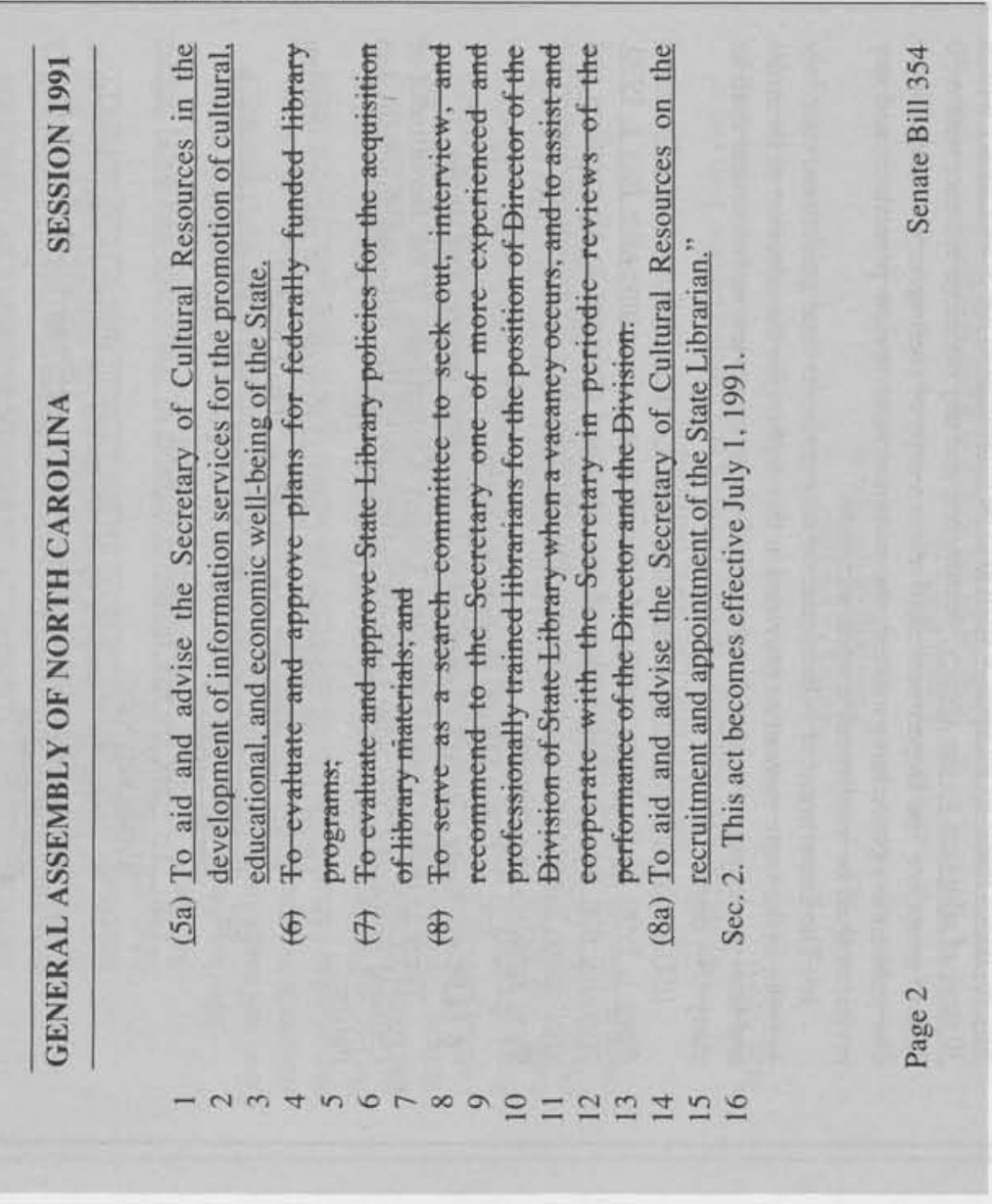

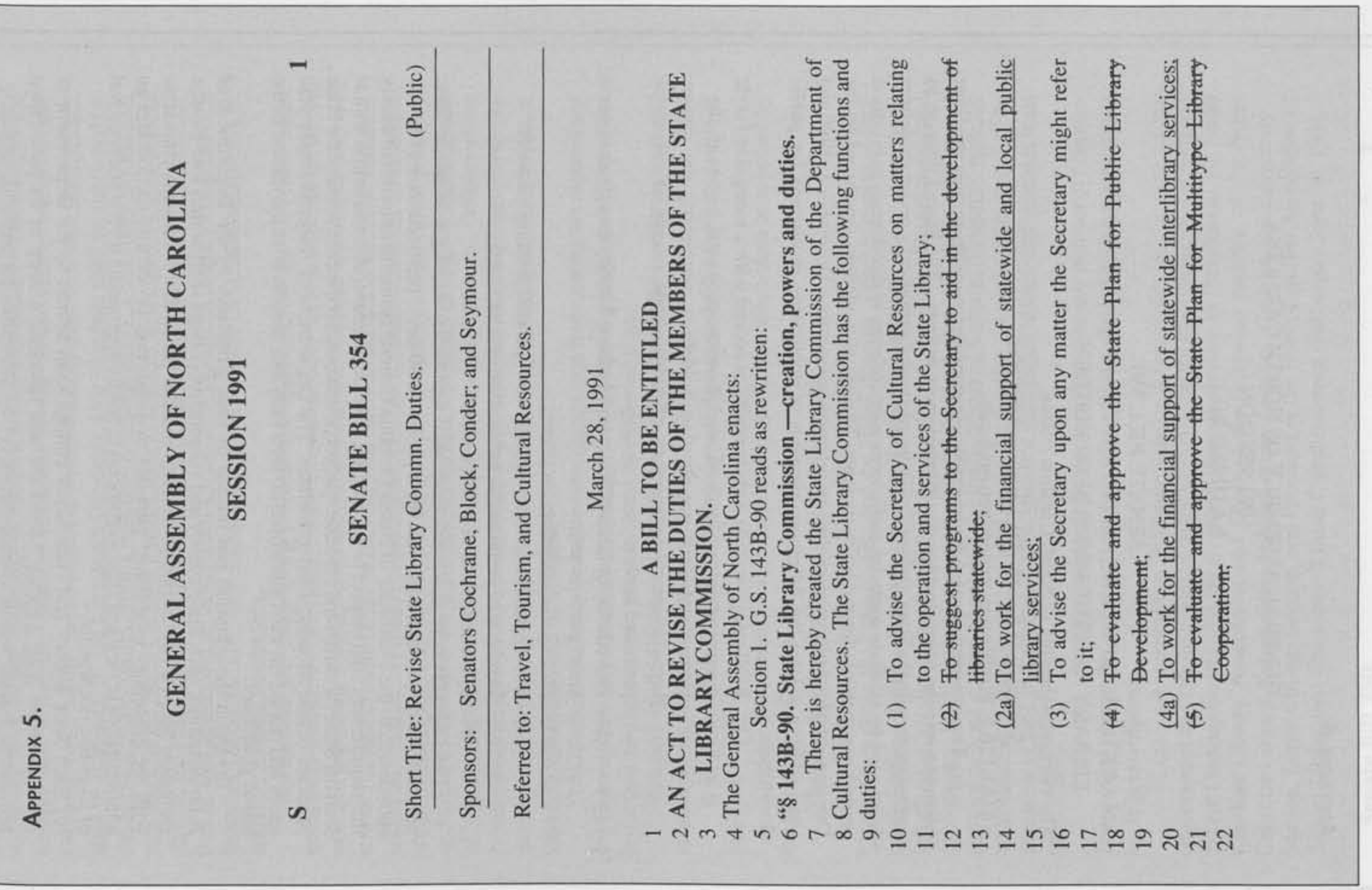



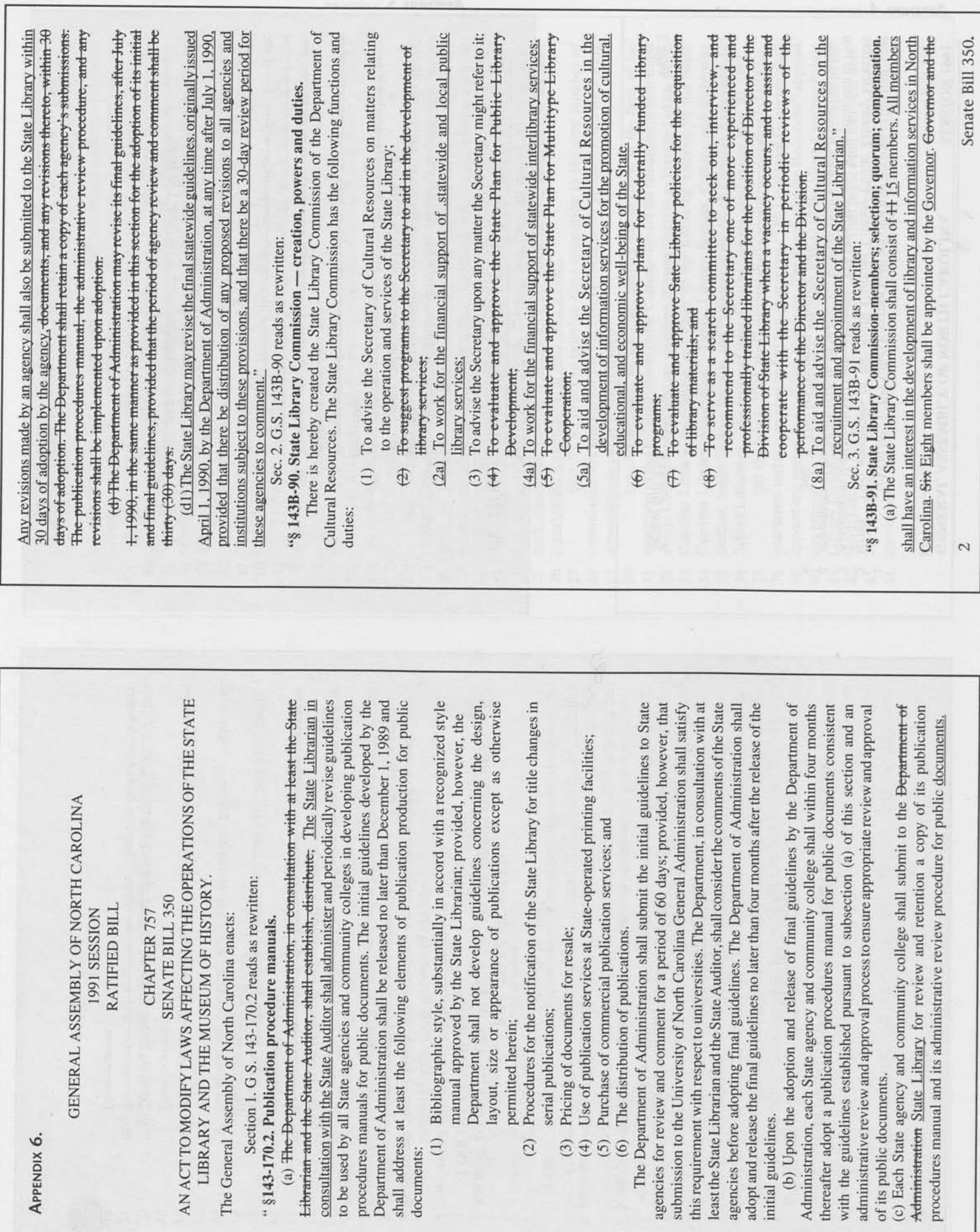
言寅

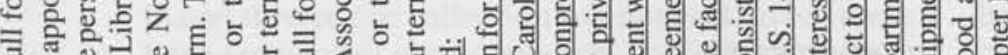
可

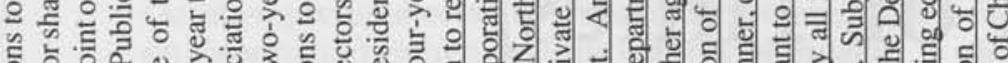

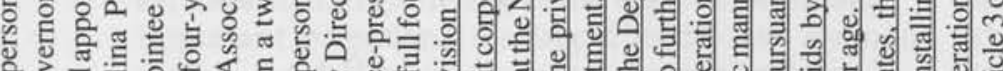

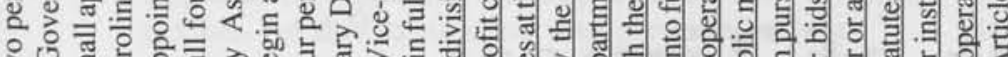

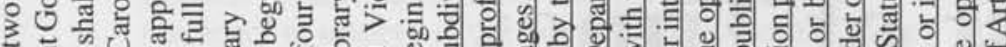

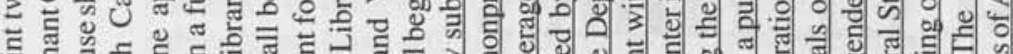

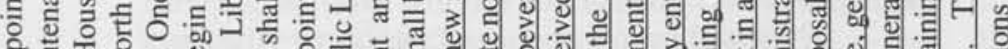
을 공 플

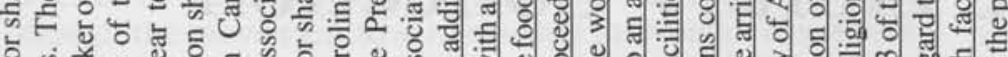

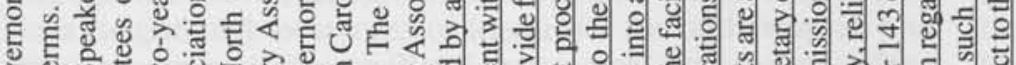

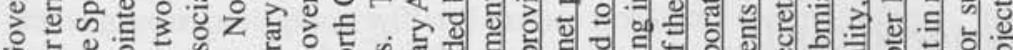

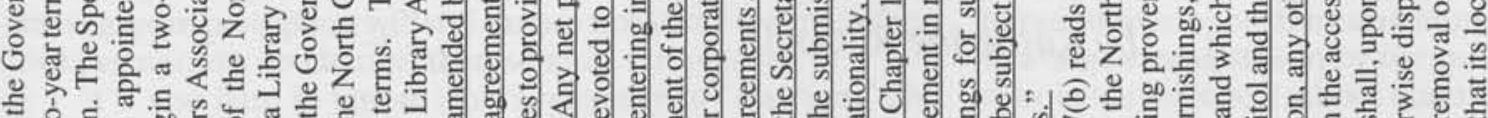
气 万人

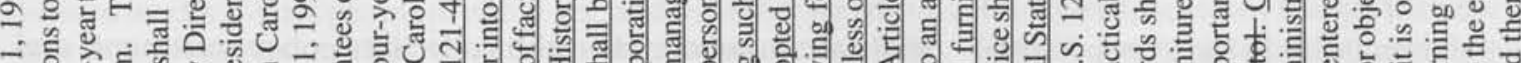
入

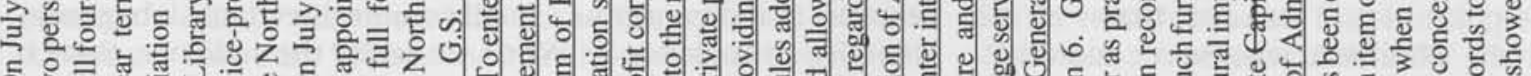

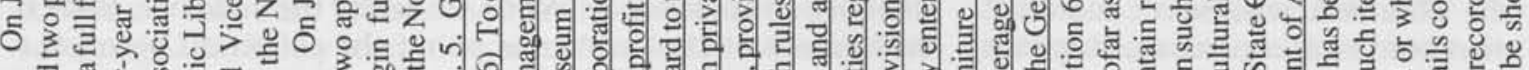
อ 疋

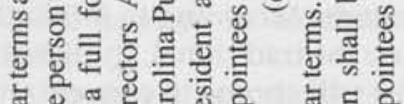
ญั๊

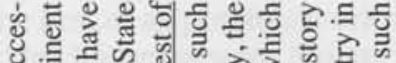

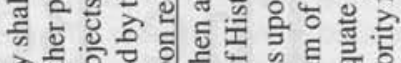

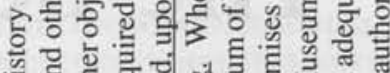

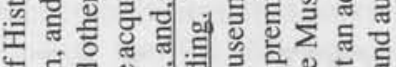

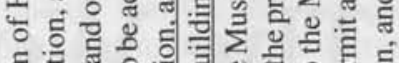

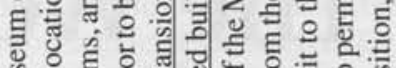

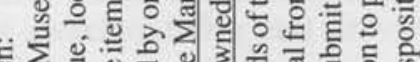
ए 들 至

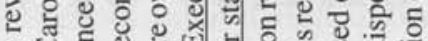

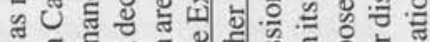

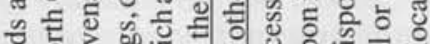
政

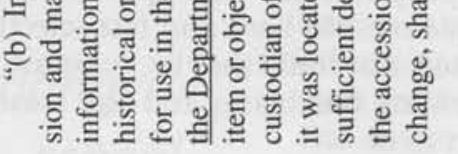

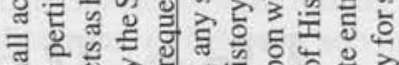

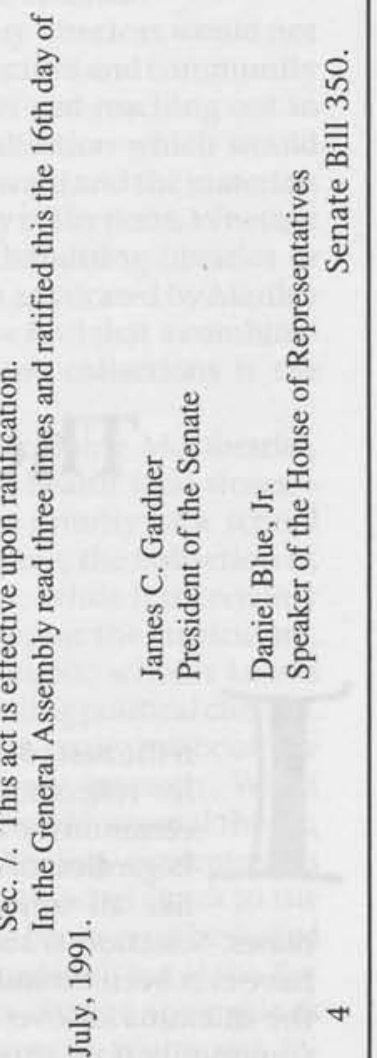

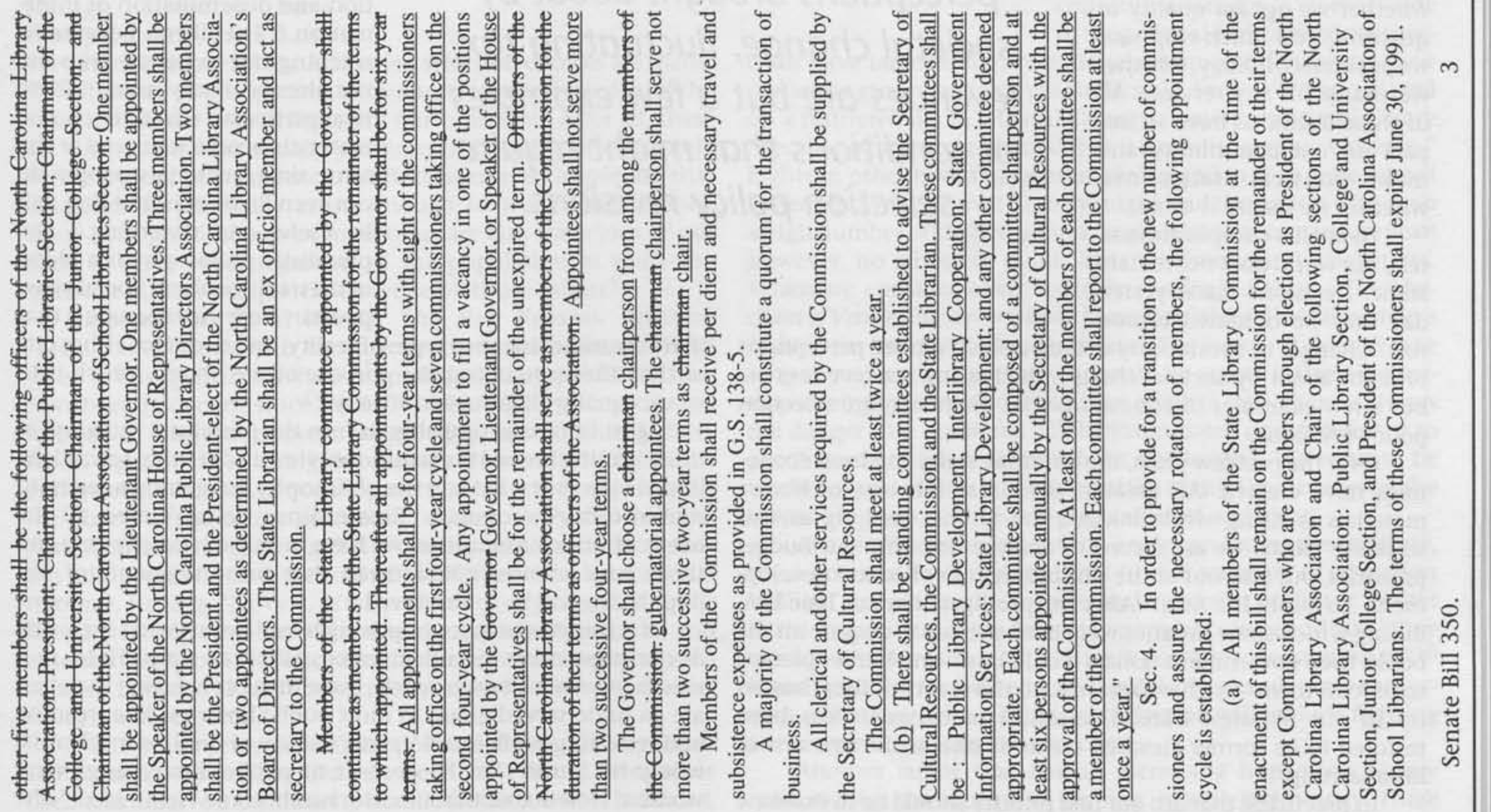




\title{
The Best of Times, The Worst of Times: The Politics of the Library Collection
}

\author{
by Katherine R. Cagle
}

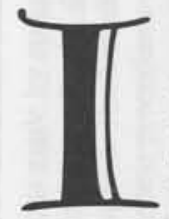

$\mathrm{n}$ the best of times, library collections have the potential for reflecting the political and personal biases of the community and the librarians who select materials. Regardless of our attempt to be non-partisan, librarians, like all other people, come equipped with personal biases. Selection is subjective. No hard and fast selection rules have ever been formulated, nor could they be, so we are left with the dilemma of overcoming our biases and the biases of the community if we expect to develop collections that are reasonably fair to our users and potential users. Any decisions we make about the collection are ultimately political - what audience we serve, how we handle censorship issues, whether we opt for quality or quantity, how much emphasis we put on technology, whether we charge for any services. All of these decisions have an impact on our community and make political statements, whether we realize it or not.

To further complicate matters, our world does not remain static. Decisions made yesterday may be outdated tomorrow. Changes in community demographics, altered perceptions brought about by societal change, fluctuating tax revenues are but a few examples of conditions that might require selection policy revisions.

Over the past few years, the national, state, and local economies have created our greatest dilemma: the cost of library materials is rising while budgets are falling. As long as this situation exists, we are forced to analyze not only our budget priorities, but also our entire philosophy of collection development. To quote Lee Ash, "After the profligate days of Title II-A, during which some libraries were hard-pressed to acquire all the books their government dollars would buy-and harder pressed to process them - we have returned to the reality of fiscal austerity in our libraries. Careful selection of materials has been restored to its former elevated status as one of the fine arts of librarianship."1

In practicing that art, our first priority should be to examine some differing views of selection policy. "Generally, the library's goals are summarized in the collection policy statement, and whether that be a page or a small volume, inevitably it begins by defining an audience." 2 When we define the audience, there is an element of choice. At this point, the collection becomes a highly political statement-what members of the community will the library serve and to what extent. According to Bill Katz, there are basically three philosophies: the traditional, the liberal, and the pluralistic. The traditionalist will choose to concentrate on giving in-depth service to those who are already library users. Traditionalists do not believe that materials should be purchased "simply because they are demanded by the public." The liberal viewpoint is basically a "belief in activism ... both in selection and dissemination of information." The liberal believes in reaching out to people who are not already library users. "There is a particular effort to choose materials people want and at the same time, materials people do not even know exist but that will be useful and rewarding." The pluralistic philosophy is a blend of the traditional and liberal viewpoints. "Here the rationale is that there are more than two types of reality, and to opt for either one or the other is to defeat the purpose of the library, which is to serve, equally all groups in society." 3

Most librarians probably fit into the pluralistic category, at times leaning toward the traditional view and at times toward the liberal view; but whatever the philosophy, pragmatism seems to rule in today's economic climate. Since we can't meet all the needs of our communities, we have to make hard choices, and those hard choices could mean that some segments of our population will be underserved.

It is sometimes quite surprising to realize just what segments of our population are underserved. Librarian Carol Hole, in a recent American Libraries article, came to the conclusion that men are an underserved group in most public libraries. After reading and reflecting on Bernard Vavrek's study of rural Pennsylvania, where he found that 80 percent of public library users were women, Hole stated that libraries had become "feminized." She concluded that public library collections often leaned heavily 
toward materials of interest mainly to women, while neglecting more technical fields. The results of this feminization

[have] skewed our collection balance and driven away a large segment of our population, including most men. Our attempts to correct this have caused an overemphasis on information gathering at the expense of equally important recreational reading of both fiction and nonfiction. Yet due to subconscious classism and our tendency to underrate the demand for books on "male" subjects, we have still not succeeded in attracting men, especially working-class men to our libraries. ${ }^{4}$

This is a good example of how our perceptions can change as a result of societal change. In this case, we can see that even though the movement toward equality for women has resulted in a heightened awareness of inequities for both women and men, gaps in perception will still surface from time to time. When our perceptions do change, then so must our policies.

It is also hard to ignore Hole's reference to "classism." She asserts that "[1]ibraries have a long, depressing history of hostility toward working-class people of either sex, and, whether we admit it or not, when we don't buy what they want to read, we send the message 'we don't want your kind in our library."'5 In a similar statement, Katz said, "The economically and educationally disadvantaged (and they tend to be much the same) are locked out of the library by barriers which need to be carefully studied." 6

From a pragmatic point of view, it is easy to understand the existence of barriers that lock out the economically and educationally disadvantaged. There is a history of intellectual elitism in most educational and cultural institutions. Even though libraries have changed greatly, there is still a remnant of that elitism. And when selection choices are made, the influence of the business community, the educated, and the affluent is likely to be reflected in our collection. After all, these are the people who occupy positions of power that ultimately determine our very existence. While it is certainly important that librarians be politically astute enough to win friends among those with political power, most of us are also conscious of our need to serve other segments of the population as well-the question is, how adequately do we serve those others?

Stephen Akey's article in The New Republic entitled "McLibraries" deals with another direction some libraries have taken to ensure their survival. According to Akey, public libraries have been in decline since the 1970s when library directors and trustees, in reaction to severe budget cuts, began boosting circulation figures "by stocking the shelves with trash." While this policy seems to work in boosting circulation and thus justifying the library's request for additional funding, Akey also believes that libraries are neglecting their "traditional constituency: serious adult readers" and the role of the library as an educational resource. He says, "No one, as far as I know, is arguing that public libraries should stop buying and making available popular and entertaining books. Yet traditionally libraries have maintained a balance between their functions as a leisure activity and as an educational resource."7

Will Manley presents a similar point of view in the November 1990 issue of Wilson Library Bulletin. He believes that "... the people need and deserve a community book collection that is balanced, diverse, and of the highest quality." As Manley says, "America does not need public bookstores. It needs public libraries ."

In the best of all possible worlds, library directors would not be forced to choose between having McLibraries and community book collections, or between serving users and reaching out to non-users, but would have a balanced collection which would include both the popular materials people want and the materials that have been traditionally a part of library collections. Whether today's budget worries will find us merchandising libraries or providing the community book collection advocated by Manley is a question still to be answered. Or will we find that a combination of merchandising and providing book collections is the answer?

If public libraries are in danger of becoming McLibraries, school libraries are in danger of becoming health food storeshaving vitamins but no dessert. The first priority of a school library is to support the curriculum; therefore, the collection is, to a large extent, driven by the curriculum. While it is certainly reasonable to expect school libraries to support the curriculum, anyone who has followed the history of public schools knows that the curriculum changes with the prevailing political climate. The cry for "back to basics" usually results in heavy textbook use in the classroom and little in-depth library research. When "enriching the curriculum" is the prevailing educational theme, library research is back in favor. If the English curriculum is following the trend of "back to the classics," those books must be dusted off and/or reordered; but if the English teachers change their minds and assign current adolescent literature, there is a mad dash to add extra copies of adolescent literature. School library collections are very much governed by the whims of educational trends.

Censorship attempts can also have a devastating effect on library collections. Groups from every side of the political and/or religious spectrum have targeted library materials deemed offensive by their particular group. Just this year in Florida, Snow White was placed on a restricted list in a Duval County elementary school library "because parents complained that it contains graphic violence." Eighteen other books have been challenged in that same school system this year. ${ }^{9}$ Duval County might lead the nation with such a high number of challenges in a single school system in one year; however, no school or public library is immune to challenges. When we consider other recently challenged titles-The Merchant of Venice; Huckleberry Finn; Brave New World; Shel Silverstein's Light in the Attic; and even Dr. Seuss's The Lorax -it doesn't take long to realize that our shelves would be empty if these censorship attempts succeeded. Even if an attempt fails, there is always the danger that librarians will be intimidated and decide not to purchase materials that have been challenged. We seem to be winning most of the censorship battles at this time; however, the voices of censors are still ringing out loud and clear.

At a recent conference of the American Enterprise Institute, the Associated Press reported that former secretary of education William Bennett and Georgetown University professor Walter Berns were critical of the American popular culture and said "they would welcome censorship if it were possible to reestablish it."10 If such prominent, well-educated public figures advocate censorship, our struggle for a balanced collection will include fighting the censors for a long time to come.

Another factor that has an increasing impact on library collections is the expense of keeping up with technology. There have been incredible changes in technology in the past few years. 
Installing and updating information technology in our libraries will take an increasingly larger share of our budget money. Although the benefits of information via technology are certainly without question, there is evidence that the library often has an "... inclination to put the library before the user ... most alarming is the extraordinary assumption that ordinary people may be deprived of traditionally free service in order not to disturb the technological process, and by inference, the needs of a few who profit most from the shift of concentration on collections to the concentration on processing and delivering." 11 Will we be able to continue to expand information technology, or will it be necessary to limit such services? What effect will our decisions have on the collection? And how will our audience be affected?

There are no absolute solutions to any of the issues affecting the politics of the collection, any more than there are hard and fast rules for selection. At times there seem to be more questions than answers. Each library must face the issues and deal with them according to the needs of that particular community. We must, however, remember to consider all facets of the issues. When developing a selection policy, do we try to involve people from different segments of the population? Do we conscientiously set our goals to reflect the needs of all population groups? Do we review our selection policy periodically to adjust for changes in the community? Are we aware of the political pressures and social conditions that can affect a collection? Are we, as librarians, aware of our own biases? And are we committed to keeping our library collections as free of bias as possible?

Not only do we need to keep all of the preceding questions in mind when developing our selection policies, but we constantly need to rethink the questions and generate new questions as new situations develop. We may not be able to predict the

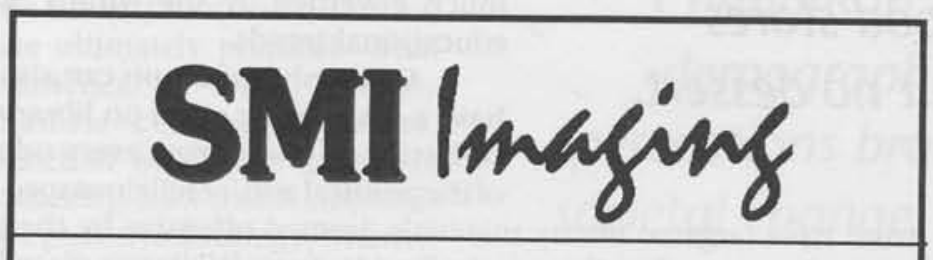

\section{Specialists in Micrographic \& Optical Imaging Technology}

- State-of-the-art electronic records management

- Microfilm, computer data, and paper imaging

- Statewide equipment maintenance

- ANSI, AIIM, \& N.C. state standards

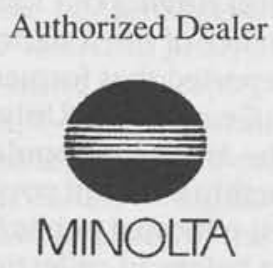

Raleigh • Charlotte - Asheville - Wilmington Call Toll Free - 1-800-532-0217 changes tomorrow will bring, but we do know that tomorrow will bring changes. Librarians must determine how to respond to the changes. We must decide what policies to revise and what policies to leave unchanged to ensure that the collection serves the entire community without bias-providing the information, the educational and cultural resources, the recreational reading, and, yes, even the "trash" if that is what our community needs.

\section{References}

1Edwin S. Gleaves, "Carter and Bonk Revisited: A Review of Recent Collection Development Literature," Collection Management 9 (Spring 1987):80.

2 William A. Katz, "A Way of Looking at Things," Library Trends (Winter 1985):374.

${ }^{3}$ William A. Katz, Collection Development:the Selection of Materials for Libraries (New York: Holt, Rinehart and Winston, 1980), 18 .

${ }^{4}$ Carol Hole, "Click! The Feminization of the Public Library: Policies and Attitudes Make Men the Great Unserved," American Libraries 21 (December 1990):1079.

5Ibid., 1078.

6Katz, Library Trends, 375.

${ }^{7}$ Stephen Akey, "McLibraries," The New Republic 202

(February 26, 1990):12-13.

8 Will Manley, "Crisis and Opportunity: A Call for Quality," Wilson Library Bulletin 65 (November 1990):66.

9"Snow White Targeted by Censors in Florida," WinstonSalem Journal, (March 29, 1991):2.

10"American Culture Goes Abroad," Winston-Salem Journal, (March 11, 1992):2.

${ }^{11}$ Katz, Library Trends, 369.

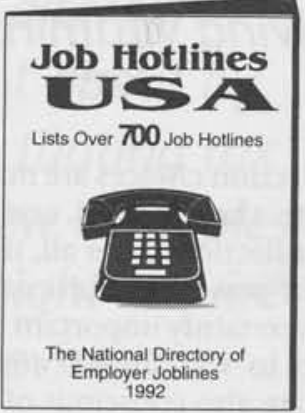

\section{Just Published!}

$$
\begin{aligned}
& \text { "State-of-the-art } \\
& \text { reference help for } \\
& \text { today's job seeker." } \\
& \frac{\text { ISBN } 1-881587-00-2}{}
\end{aligned}
$$

Job hunters need your library services now more than ever. Unknown to many of them, employers advertise thousands of jobs on recorded telephone messages every week. Job Hotlines USA, The National Directory of Employer Joblines, identifies over 700 hardto-find employer jobline telephone numbers.

- Callers dial direct to each employer. No "900" numbers. No third parties.

- Covers business, gov't., industry, education, healthcare \& military.

- All job categories, nationwide.

Published by Career Communications, Inc. Job Hotlines USA is available for $\$ 19.95$ postpaid. Call (215) $256-3134$ to order. Or write 500 Main St., P.O. Box 169, Harleysville, PA 19438 for more information. 


\title{
The Political Environment of Libraries in The University of North Carolina
}

\author{
by Benjamin F. Speller, Jr.
}

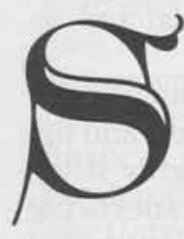

tate universities are institutions of higher education that carry out their missions, goals, and objectives with substantial financial support from the state legislature. State universities are usually given legal authority by legislative mandate or by provisions in the states' constitutions; and are governed by a board whose duties, responsibilities, and authority are established by the state legislature. By the very nature of their establishment and governance structures, state universities are generally at center stage of state politics.

The libraries of state universities, as major academic support units of their parent institutions, are also a part of state politics. Politics is often regarded as the art of getting one's preferences included in governmental or organizational policy. State universities and their libraries must seek and maintain support within the context of two basic political issues: (1) the state hierarchy for higher education ${ }^{1}$ and (2) the state budget. 2

The purpose of this article is to provide: (A) a brief description of the evolutionary process that led to the current political environment and governance structure of The University of North Carolina; (B) the strategies used by the administrators and librarians in dealing with the state budget as a political force in supporting The University of North Carolina libraries; (C) the economic and technological forces that are having a significant impact on traditional strategies that have been used by administrators and librarians; and (D) the reality shifts that must take place to ensure survival of an adequate information infrastructure to support the research and instructional support needs of The University of North Carolina.

\section{The Political Environment and Governance Structure for} State-Supported Higher Education

The University of North Carolina ${ }^{3}$ was authorized by the State Constitution of 1776 and chartered by the General Assembly of 1789 [Laws 1789 , and ch. 20.]. In 1868, the new state constitution gave more explicit recognition to the University, as did an 1873 constitutional amendment. Throughout that period, the University of North Carolina at Chapel Hill was the only statesupported institution of higher education in North Carolina. Between 1877 and 1969, the General Assembly created or acquired for the state the other fifteen institutions that are now part of The University of North Carolina.

In 1970 , the citizens of the state voted to adopt a new state constitution which took effect in 1971. Whereas the State Constitution of 1868 acknowledged the existence of The University of North Carolina, the new constitution of 1972 mandated a public system of higher education, comprising The University of North Carolina and other institutions of higher education.

The current governance structure for state-supported higher education evolved from a political environment that was consistent with the national situation. Until 1955, institutional prerogatives on initiation of new programs and related support resources for them were only controlled by the ability of the administrators and their constituencies to obtain financial resources from the General Assembly or from private or corporate donors. In 1955, a Board of Higher Education was created for the purpose of allocating functions and activities among the state-supported institutions of higher education. This organization proved to be ineffective because of its lack of authority from the General Assembly. The state-supported institutions, in fact, remained unchecked in their ambitions because the General Assembly did not have a statewide plan or set of goals for higher education. Thus from 1955 until 1969, institutional ambitions and program proliferation proceeded almost unimpeded by any major restraints.

Eventually, rising costs and the significant increase in legislative involvement in educational decisions led to a lengthy debate on the restructuring of higher education in North Carolina and, in 1971, to the creation of a Board of Governors which would be the central policy-making and governing authority for public higher education in North Carolina.

One of the political issues that most state universities have to face is where they fit within the state hierarchy for postsecondary and higher education because an institution's mission classification is used as a major funding assumption. The most widely recognized method of determining this hierarchy is the classification scheme for colleges and universities that was developed by the Carnegie Foundation for the Advancement of Teaching. 4 The Board of Governors has placed the sixteen constituent institutions of The University of North Carolina in the following categories:

1. Major.Research Universities are North Carolina State University at Raleigh and The University of North Carolina at Chapel Hill. There is currently one quasi-research institution, the University of North Carolina at Greensboro, that is placed under the research universities category as a doctoral granting university I.

The Board of Governors will probably change the classifica- 
tion in the future for East Carolina University if the expansion of its doctoral program offerings is approved, and changes are expected for North Carolina Agricultural and Technical State University and the University of North Carolina at Charlotte if proposed new doctoral programs are authorized. These institutions will probably be designated as doctoral granting universities II by the Board of Governors.

2. Major Comprehensive Universities are Appalachian State University, East Carolina University, Fayetteville State University, North Carolina Agricultural and Technical State University, North Carolina Central University, University of North Carolina at Charlotte, University of North Carolina at Wilmington, Western Carolina University.

3. Regional Comprehensive Universities or Colleges are Elizabeth City State University, Pembroke State University, the University of North Carolina at Asheville, Winston-Salem State University.

4. Major Schools of the Fine Arts. North Carolina currently has one institution in this category, North Carolina School of the Arts.

\section{The Systems Context of State Budgeting for The University of North Carolina Libraries}

The budget is a major force in state politics. Nearly all political activity centers around state budget appropriations. 5 A state system of higher education is usually considered a subsystem of the total system of state government. The subsystem for budgeting is usually composed of at least four components: (1) the state executive budget office, (2) the state legislative committees and staffs, (3) the state higher education agency (a few states do not have this unit), and (4) the institutions of higher education. The budgeting system for The University of North Carolina operates in this context.

Budget preparation in North Carolina is based on constitutionalauthority. ${ }^{6}$ The North Carolina Constitution requires the Governor to "prepare and recommend to the General Assembly a comprehensive budget of the anticipated revenue and proposed expenditures of the state for the ensuing fiscal period." The Uni-

versity of North Carolina is the state's higher education agency which is composed of the Board of Governors, The UNC General Administration with a chief executive officer, the president, and the sixteen institutions with their chief administrative officers, the chancellors. The President of The University of North Carolina and his staff prepare for the Board of Governors the recommended higher education budget for the state. Budget preparation is based on formulas, economic assumptions, budget guidelines, University priorities, and other data.

The Director of Libraries at each one of the sixteen constituent institutions of The University of North Carolina is responsible for communicating the requirements for respective campuses to the campus Chancellor. Communicating the sixteen libraries' requirements to the UNC President and the Board of Governors is equally important because the staff of the UNC system must be strongly committed to the development of libraries within the system; they make decisions about the proper development of libraries within the system and about the allocation of state budget funds to the UNC university libraries. The campus chancellors have not always agreed with a direct communication process by the librarians to the system-wide administration and the UNC Board of Governors. However, this direct communication process has been the most effective strategy for keeping the Board of Governors staff apprised of the special needs of libraries in The University of North Carolina. This communication process has been implemented through the University Library Advisory Council (ULAC) which is composed of the head librarians of the sixteen institutions in The University of North Carolina. ULAC was originally organized in 1969 by the Board of Higher Education to advise on funding and improvement of North Carolina's public university libraries.

Prior to 1969 , planning and funding of the state's public university libraries were the responsibility of each local institution. Adequate library resources for each campus depended upon the priority which each university administration gave to its library as well as the institution's political strength and influence in obtaining funding from the North Carolina General Assembly. The natural outgrowth of this highly political process was a lack of equity in funding among the institutions and inadequate support of libraries, both at the local and state levels. The smaller, less influential state-supported institutions all had inadequate library resources for the support of their instructional and research programs.

The work of the Board of Higher Education through ULAC has continued since 1972 under the Board of Governors and the UNC General Administration. An extensive and highly structured planning process resulted in state university libraries being a consistently high priority of both the Board of Governors and the North Carolina General Assembly, providing substantial financial support from 1969 until the current state economic slow-down. This strong support has resulted from studies by ULAC as well as consultants employed by the Board of Governors. The formula-based assumptions were developed in keeping with nationally recognized indicators and measures for library resource allocation for college and research libraries. The formula-based assumptions were also matched with a set of enrollment assumptions for each university. 7

Most recently ULAC has also focused its efforts on improving access to resources and services at the institutions in The University of North Carolina through automation and computer communication network-

ing. Although the Automation/Networking Committee is assigned specific responsibility for coordinating this effort, all committees of ULAC-Budget, Cooperative Issues, Personnel, and Statistics-have been assigned responsibilities which have a direct impact on its successful implementation.

Coordinated planning for library development of The University of North Carolina has resulted in equitable funding and increased annual library expenditures during nearly every biennium since 1972 for each of the sixteen institutions and has led to significant progress for resource sharing through cooperative programs and through the North Carolina Information Network administered by the State Library of North Carolina. The work of ULAC has provided significant results in improving library resources for support of instructional and research programs, although increasing costs of library materials and technological developments and current economic constraints have seriously eroded the value of the state's financial support of its university libraries.

\section{Economic and Technological Forces}

The major forces that have had a significant impact on the political environment of The University of North Carolina libraries can be categorized as economic and technological in nature. Much is being communicated by the academic library leaders, 
both locally and nationally, about the stringent times in which libraries are operating. They have cited three major causes: escalating cost of materials and services, shrinking budgets, and the impact of new technologies on library operations and in information handling. 8

Nearly all national library leaders are predicting that during the next decade a dramatic transition away from manufacturing of printed products will result in the distribution of instructional and scholarly information through a variety of media formats. ${ }^{9}$ The mission of the research university is changing in response to the use of new electronic technology. 10 The communication and computing network technologies are forcing the development of a restricted knowledge communications infrastructure for universities and a re-examination of institutional missions. The research paradigm is changing because the electronic communication networks allow more emphasis on "the invisible college" as a means for reporting results rather than full published research outcomes. These are all highly political forces because they affect long held assumptions and values upon which goals, objectives, and programs of the university libraries have been based.

All economic indicators at this time would suggest that the financial situation will not significantly improve nor will the purchasing power of the dollar increase or even remain stable. If The University of North Carolina receives a modest reduction in budget allocation or even a modest increase, the University's libraries are still going to be faced with significantly diminished purchasing power for materials. The consequences of reducing purchasing power might well lead to homogenous collections and a loss of the current levels of quality in the state's research collections, especially if the traditional academic and research library assumptions are not changed.

Another political complication resulting from the move toward electronic information is the issue of who manages or provides the leadership for the electronic communication channels for information handling, the library or the computer center. ${ }^{11}$ The state legislature might well get involved in this issue unless there is careful and visionary planning by the administrators of the University libraries and computer centers. ${ }^{12}$ An added political dimension might result at the campus level as administrators and faculty determine the priority in funding the mechanism for providing adequate access to shared library resources through the proposed University of North Carolina Library Network, the North Carolina Information Network, the North Carolina Integrated Network, and the National Research and Education Network/Internet. These forces have caused ULAC to examine and study ways to maintain adequate library resources to support The University of North Carolina's instructional and research programs.

North Carolina's research university libraries must re-think fundamental and treasured assumptions. Failure to do this will have negative academic and political consequences. These treasured assumptions include:

1. The best libraries are those with the most physical resources and greatest number of monographs and active serials.

2. Libraries must buy comprehensively across all disciplines to assure that some unknown title purchased today will be available when needed at some point in the future.

3. Ownership is the ideal and desirable situation.

4. It is more cost effective to own everything that might be needed than to expend resources only on what is needed at the time it is needed.

The problem is especially significant because the current assumptions have been presented so convincingly to legislatures, employers, alumni, and private donors, that changing them will require some serious planning and effective communication with the legislature and other constituencies as was done in 1969 and 1972.

\section{Reality Shifts}

Physical ownership of collections falls in the basic human need category; therefore, the political motivation is very strong to look with pride at very large collections. Although some university libraries are having problems in maintaining large collections and there is much discussion of cooperative or coordinated collection development, the traditional paradigm for acquisition of materials is in still in place. Will ULAC make the reality shift to a more effective plan for using the electronic format and communication channels for on-demand access? Or to a more effective means of managing limited financial resources for collection development?

The economic and technological conditions suggest that a more systematic plan for collection development could guide funding and budget allocation. The criteria for such a plan would be: collect to satisfy the greatest number of local users, collect to satisfy known immediate-and future need, and collect as part of a shared state and national collection plan. Will ULAC make the reality shift to more effective criteria for collection development and budget allocation?

A major political issue might be how to divide and assign responsibility, particularly to those academic libraries that support external research and governmental users as well as some information needs for the general public. Another political issue is who will experience the benefits when using what resources. Members of ULAC and other leaders have rightly expressed concern about how access to the benefits of networked information resources and services is obtained. ${ }^{13}$ Will ULAC serve as a model for designing a set of criteria in keeping with their institutions' assigned functions and programs? Will ULAC again take on the issue of how best to deliver the information? Will ULAC recognize that the current interlibrary loan system is much

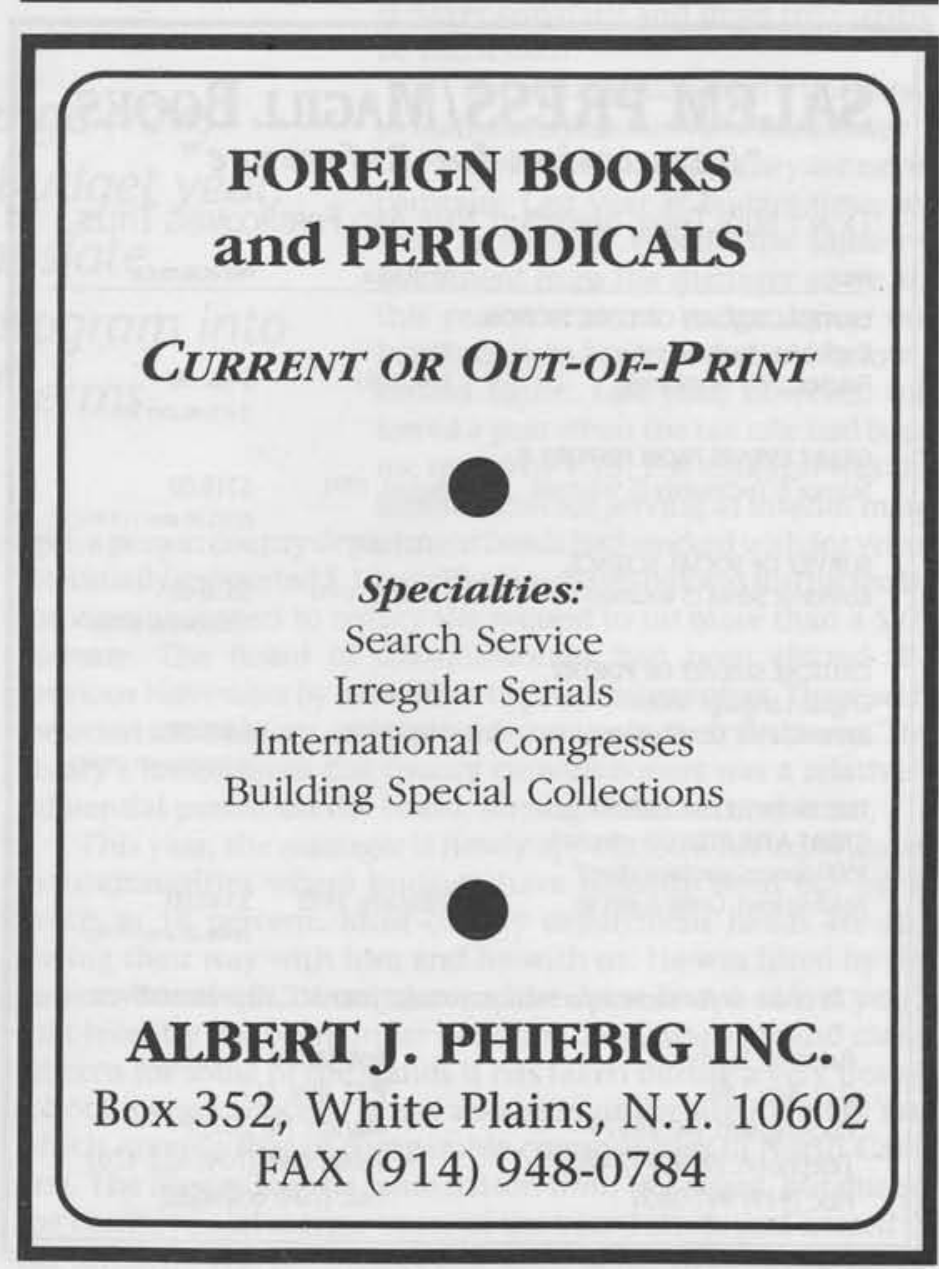


too slow as a backup strategy in the resources sharing paradigm? Another issue which is probably the most political internal question for ULAC is how to embed networked information resources and services into the research and teaching communities. Will ULAC take on the issues of how to refit institutional and organizational facilities, how to reallocate institutional and organizational budgets, and how to re-educate professional and support personnel?

\section{Summary and Implications}

The University of North Carolina receives a significant portion of the state's budget. The state budget is derived from a highly political process; therefore, the University is a significant entity in state politics. The University libraries are affected by state politics but not as much during previous years because of the high priority given to adequate library resources by the Board of Governors and the University-wide administrators. ULAC was very effective in communicating needs directly to the Legislature through the Board of Governors because of excellent research, evaluation, and planning which resulted in a convincing case for financial support for library resources.

Most recently, severe financial pressures and technological developments are forcing university officials to re-think institutional priorities. The economic climate and structural changes will have a significant impact on the political environment in which The University of North Carolina libraries seek funding for adequate resources to support instructional and research programs. Although ULAC appears to be making positive efforts in consolidating the gains of technological advancement, additional support from the UNC General Administration and the Board of Governors is needed. Support is needed to conduct some studies of how national and state structural changes have affected current assumptions that guide the budgetary process for

\section{SALEM PRESS/MAGILL BOOKS "Reputation for Reference"}

\section{Don't Miss TheSe Important NeW And ForThComing Titles}

\begin{tabular}{|c|c|c|}
\hline TIILE & AVAILABLE & PRE-PUB PRICE \\
\hline $\begin{array}{l}\text { CRITICAL SURVEY OF LONG FICTION, } \\
\text { English Language Series } \\
\text { Revised,1991 ( } 8 \text { volumes) }\end{array}$ & July, 1991 & $\begin{array}{l}\$ 400.00 \\
(\$ 475,00 \text { after io/1/91) }\end{array}$ \\
\hline $\begin{array}{l}\text { GREAT EVENTS FROM HISTORY II, } \\
\text { Science } \bar{\alpha} \text { Technology ( } 5 \text { volumes) }\end{array}$ & August, 1991 & $\begin{array}{l}\$ 318.00 \\
(\$ 375.00 \text { after II/1/91) }\end{array}$ \\
\hline $\begin{array}{l}\text { SURVEY OF SOCIAL SCIENCE, } \\
\text { Economic Series ( } 5 \text { volumes) }\end{array}$ & October, 1991 & $\begin{array}{l}\$ 318.00 \\
\text { (\$375.00 after 2il/92) }\end{array}$ \\
\hline $\begin{array}{l}\text { CRITICAL SURVEY OF POETRY, } \\
\text { English Language Series } \\
\text { Revised, } 1992 \text { ( } 8 \text { volumes) }\end{array}$ & May, 1992 & $\begin{array}{l}\$ 400.00 \\
\text { ( } \$ 475.00 \text { after } 11 / 30 / 92 \text { ) }\end{array}$ \\
\hline $\begin{array}{l}\text { THE TWENTIETH CENTURY, } \\
\text { GREAT ATHLETES ( } 20 \text { volumes), } \\
1500 \text { photos/ graphics/ charts } \\
\text { Reading level: Grade } 6 \text { and up }\end{array}$ & February, 1992 & $\begin{array}{l}\$ 340.00 \\
(\$ 400.00 \text { after } 711192)\end{array}$ \\
\hline
\end{tabular}

To order or for more information, contact your N.C. Representatives:
Ralph M. Davis
P.O. Box 144
Rockingham, NC 28379
Telephone: (919) 997-4857
Fax: (919) $997-3837$

The University of North Carolina libraries, as well as for each institution's own internal allocation process for library resources. The recent mission review of The University suggests that a significant window of opportunity exists to seek support for an in-depth study of the statewide library resources and access needs within the context of the proposed revision of the state hierarchy for higher education. The needs of The University libraries must be viewed in the context of the current crisis in the scholarly communication infrastructure ${ }^{14}$ and participation in the electronic information access environment of the North Carolina Information Network, the North Carolina Integrated Network, 15 National Research and Education Network/Internet, the Coalition for Networked Information, 16 and others.

\section{Reference and Notes}

${ }^{1}$ Benjamin F. Speller, Jr., "The State University Library and Its Political Environment," in E. J. Josey and Kenneth D. Shearer, eds., Politics and the Support of Libraries, (New York: Neal-Schuman, 1991), p. 95.

2 David Shavit, "The Politics of the State Budgetary Process and Library Funding," in E. J. Josey and Kenneth D. Shearer, eds., Politics and the Support of Libraries, (New York: Neal- Schuman, 1991), p. 87.

${ }^{3}$ The description of the governance structure of The

University of North Carolina in this article is based on Chapter II of LongRange Planning, 1986-1991, (Chapel Hill: The University of North Carolina Board of Governors, 1987), pp. 11-23.

${ }^{4}$ A Classification of Institutions of Higher Education,

(Princeton, New Jersey: Carnegie Foundation for the Advancement of Teaching, 1987).

5Speller, op. cit., p. 96.

${ }^{6} \mathrm{~A}$ full description of the budgetary procedures for the state of North Carolina based on constitutional authority is presented in the Budget Manual, (Raleigh, North Carolina: State of North Carolina, Office of State Budget and Management), Section 2, pp. 1-14.

7 An historical description of long-range planning for support of libraries of The University of North Carolina is presented by I. T. Littleton, "Planning and Funding For Public University Libraries in North Carolina," North Carolina Libraries, (Fall 1978): 30-37.

8 Peggy Johnson, "When Pigs Fly, Or When Access Equals Ownership," Technicalities, (February 1992): 4.

9Peter R. Young, "Knowledge Communities and Information Network Policies," 12th Yuri Nakata Lecture, (Chicago: The University of Illinois at Chicago, University Library), pp. 5-6.

10Richard M. Dougherty and Carol Hughes, "The Changing Culture of the University," Library Issues, (January 1992).

${ }^{11}$ Marilyn J. Martin, "Academic Libraries and Computing Centers: Opportunities for Leadership," Library Administration \& Management, 6 (Spring 1992): 77-81.

12Joan Blair, "The Library in the Information Revolution," Library Administration \& Management, 6 (Spring 1992): 71-76.

13Paul Evan Peters, "Networked Information Resources and Services: Next Steps," Cause/Effect, (Summer 1991): 38.

${ }^{14}$ Charles B. Lowry, "Converging Information Technologies: How Will Libraries Adapt?" Cause/Effect, (Fall 1990): 35-42.

15State Information Processing Services, Information Resources Management (IRM) Strategic Direction, FY 1991-92, Raleigh, NC: State of North Carolina, Information Technology Commission, 1991.

16 The Coalition for Networked Information is an activity of the Association of Research Libraries, CAUSE, and EDUCOM. The mission of the entity is to promote the creation of and access to information resources in networked environments in order to advance scholarship and intellectual productivity.

\section{Additional References}

Steve Bankes, and Carl Builder, "Seizing the Moment: Harnessing the Information Technologies," The Information Society, 8 January March 1992): 1-59.

Guidelines for University Administrative Information Resources Management, Blacksburg, Va: Virginia Polytechnic Institute and State University Policy and Procedures Section 2005.

Michael J. Ross, State and Local Politics and Policy: Changes and Reform. Englewood Cliffs, N.J.: Prentice-Hall, 1987.

Aaron Wildavsky, The New Politics of the Budgetary Process. Glenview, Ill.: Scott, Foresman, 1988. 


\title{
The Public Library's Political Agenda
}

\author{
by Dale Gaddis
}

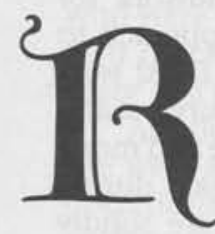

ecently, the County Manager called all major department heads together to tell us that, although we had just prepared our budgets for 1992-93 using a nogrowth benchmark, he now wants us to cut our nogrowth figure by 2.5 percent to enable the county to fund an employee compensation package, the new initiatives the commissioners established last year, and mandated social service increases. He is requiring this of departments before even looking at the budgets we have already prepared. The cut is required to keep the taxrate increase for operations less than $\$ .02$, an expectation of the County Commission.

This meeting marked the beginning of the political maneuvering which occurs every budget season. Our challenge now, as it is every budget year, is to translate the library's program into political terms. A similar challenge is faced when having to deal with controversies over such issues as censorship attempts, homeless in the library, service curtailment, or any number of other issues. What is our agenda in these situations and how can it be defined so that it gains support from those with power in the community?

It has been my experience that, if a library is to progress, it is helpful to have a political agenda that is developed from the following basic elements: an analysis of the political climate in which we are working, a dedication to professional library ideology and our institution's mission and goals, a clear understanding of the community's needs for library services, and established goals for service development which address the community's needs and priorities.

\section{Assessing the Library's Political Climate}

In his book, The Politics of Public Librarianship, David Shavit claims something that we should not allow to be true: that public libraries generally are insulated from public opinion and influence and the "relevancy of the community's power structure is slight." He says that professional library bureaucracy makes decisions which are rarely questioned, that public libraries have few constituencies, and library services do not provide focus for organized lobbies. 1

Many librarians argue that public libraries should be apolitical and, as a result, many libraries are. This argument stems from the belief that services and policies should be developed objectively by trained professionals and that neutrality in politics is required to ensure that all individuals in a community are served equally and that the organization is viewed as a non-partisan one from which all can benefit.

While the philosophical basis of the argument may be sound, library development and support can suffer if we do not recognize the political nature of the climate in which public libraries operate and of our professional ideology. According to Shavit, in good times life may be easier without organized constituencies, but this lack of public involvement boomerangs in bad times. ${ }^{2}$

In order to utilize the political climate to the library's advantage, forces shaping that climate must be understood: the power structure of the community, current political issues which could impact either the library directly or the power structure, economic conditions, editorial policies and stances of the local media, level of activism of the citizens, and internal administrative politics, to name a few. Because these forces continually change, the climate is never constant and must frequently be reassessed.

The current political environment in Durham is illustrative of the elements I have identified and how they are never constant. Last year at budget time, we were faced with exactly the same requirement from the manager as we are this year: to cut our budget below our benchmark to keep the tax rate below a certain figure. Last year, however, followed a year when the tax rate had been inc reased by $\$ .16$. The manager was the finance director serving as interim manager, a person county department heads had worked with for years. He initially supported $\$ .19$ worth of increases but was instructed by the commissioners to reduce the request to no more than a $\$ .03$ increase. The Board of Commissioners had been elected the previous November by a coalition of progressive voters. Three were reelected incumbents and two were serving in their first term. The library's liaison from the county commissioners was a relatively influential person on the board, serving in her second term.

This year, the manager is newly appointed with experiences in communities where budgets have recently been cut by as much as 18 percent. Most county department heads are still feeling their way with him and he with us. He was hired by the current Board of Commissioners, the same board as last year's that recently has been under fire from the newspaper and many citizens for some of the stands it has taken during a very heated school merger process. It has also been under fire for a tax rate which exceeds that of comparable communities in North Carolina. The library has the same liaison from the board, but during the controversial merger votes of the board she found herself in the minority and potentially lost some of her negotiating power 
with the other commissioners. It is an election year.

\section{Professional Ideology: a Key to the Library's Political Appeal}

In what way can a political agenda be developed to enable the library to progress in such a climate as this? First of all, we need to have a basic understanding of and commitment to our professional ideology. How this ideology relates to the political climate is the subject of William Birdsall's 1988 article in Library Journal entitled "The Political Persuasion of Librarianship." 3 Birdsall provides an excellent analysis of the basic political tenets of librarianship and how librarianship has related historically to the American political environment. It presents the thesis that American culture consists primarily of liberal tenets, and that these tenets accommodate a wide range of paradoxical political attitudes "whose center of gravity shifts back and forth from left to right and that librarianship's ideology tracks these more general shifts." 4

The history of liberalism in this country, according to Birdsall, has been that of an ideology which stresses the individual and respect for individual rights, self-fulfillment intellectually and economically, a rational and utilitarian orientation, and equality of opportunity, coming to play against the "conservative's attachment to hierarchy, family, and tradition," and the socialist's emphasis on equality of result. 5

Likewise, library ideology has embraced basic liberal tenets, which are the bases for our professional stance with regard to intellectual freedom and censorship, for the development of libraries as resources geared to serving the needs of the individual, for the emphasis on the need for trained experts to administer the library function, and for the utilitarian idea of the library ("the best reading for the largest numbers at the least cost" 6 ): Throughout their history, libraries have also been considered by many to be a safe place, providing stability to a community, and thus promoting a conservative ideal. Library efforts to reach out to extend services rather than assume that the reader will be self-motivated to use the library have been a response to the more socialistic idea prevalent since the 1960s that equality of result does not always occur if society depends on independent action by individuals.

According to Birdsall, "because [library ideology] incorporates a wide range of political perspectives, it is able to draw on support from a diverse constituency." 7 Herein lies the hope and the possibilities for me in this political year and for all of us during times of controversy: that support is out there for libraries from the full range of the political spectrum.

\section{The Library Mission as \\ "Guiding Beacon"}

The paradoxical political attitudes inherent in library ideology require us to be extremely careful when we develop our political approach to consider the possible long range impacts on both our own libraries and on the profession as a whole, along with the local and immediate political effect of our actions. Henry T. Blanke in his Library Journal article entitled "Librarianship and Political Values: Neutrality or Commitment?"8 warns against allowing ourselves "to drift into an uncritical accommodation with society's dominant political and economic powers." $9 \mathrm{He}$ declares the need for librarians to have a "clear and vital set of philosophical and political ideals acting as a guiding beacon." 10 The individual library's mission should be a statement of those ideals as they apply to the local community.

Our professional ideology is most tested in times when the various roles libraries play in a community come into conflict with each other. Political support for the library can be jeopardized if the library attempts to face these controversies without a clear statement of the library's mission to serve as a "guiding beacon."

\section{Controversy as a Political Opportunity}

During my tenure as library director in Durham, we have encountered several controversial situations. Some we have handled successfully, others perhaps not so successfully. Only recently have I thought much about these situations in political terms. It has been my belief that a firmly grounded principled stand will more often than not get the library through a controversy. I have also believed that one is always laying the groundwork for support during difficult times with one's general approach to service in good times. In the past, however, when faced with controversy, my most immediate objective has been survival and damage control, not long term political benefit. More and more, however, I am realizing the power the library can gain during controversy when it takes principled stands that are solidly grounded in an understanding of and caring for the community, combined with a commitment to professional ideology and our own library's mission. These stands set the stage for more respectful and supportive future responses from politicians, the media, and the community as a whole.

The controversy for which Durham is probably most known, and the one that caused the most political furor, was the controversy over a gay rights display in the library. The library has always subscribed in its mission and goal statements to the Library Bill of Rights and to its emphasis on providing materials and information representing all points of view. The library had therefore often hosted potentially controversial exhibits and meetings, but had received little negative comment. When the staff informed me that the Lesbian and Gay Health Project had requested to use our display cases for a month as part of a community-wide celebration of Gay Rights Week, I did not foresee any problems. I was told that the Mayor of Durham had also agreed to proclaim the week to be Anti-Discrimination Week. My impression was that Durham was a liberal community that would generally support the anti-discrimination sentiments of the exhibit and the proclamation. I was only partially right: only part of the community supported these sentiments; a larger group than I would have predicted had strong sentiments against gay rights and the display in the library.

As soon as the exhibit appeared and before I had even seen it, I received a complaint. It was a Saturday. By Monday morning, we had received numerous complaints and I was being told in no uncertain terms by the County Manager that I had to remove the display because the commissioners were receiving calls. I took a deep breath, "calmly" explained to him our display policy and invited him to come view the display before requiring me to remove it. He agreed to do that, as did the library board chairman upon my request. Both agreed that the exhibit fell within the guidelines of our display policy and should not be removed. The manager then defended the library's stand to the commissioners and to the many citizens who called his office during the month the display was in place. (This is the same manager who a couple of years later gave permission for a giant balloon in the shape of 
a condom to be flown over the county stadium as part of a community-wide AIDS awareness effort - the commissioners decided in this situation not to support the manager's decision.) We also successfully defended our stand to the local newspaper, which subsequently provided editorial support for our actions.

Because the exhibit was in place for a month, gaining the support of the manager, commissioners, board, and newspaper was only the beginning of the furor in which we found ourselves. Daily we received both complaints and compliments. The newspaper's editorial page was extended beyond its usual single page to include large numbers of the letters written on both sides of the issue. We became less the target of complaint when the mayor issued his proclamation, but then became a site for community efforts to recall the mayor. The people in town who were upset with our exhibit discovered quickly that they could use the library as a public forum as well, and did.

Although this was an exhausting time (we were also trying to maintain normal operations and get a budget passed), it did provide us with an opportunity to gain a better understanding of the political environment in our community and the expectations the public has for its library. We were also able to educate the public about the library's role as a public forum and a promoter of intellectual freedom. Many of the public had only thought of a library from the conservative viewpoint that the library is a safe place, a place which provides stability to a community. They considered the display a violation of public trust. They had not thought of the library in its potentially more threatening role of encouraging public debate. I am not sure the library staff and board had even thought of the full ramifications of this role until we were faced with this controversy. During the month, we had many discussions $w$ ith people who were angered by the point of view being displayed in our exhibit cases. Most were grateful for the time we spent listening to their point of view and many came to respect the role the library was playing as public forum. As a result of this controversy, the community gained an understanding and appreciation for the many roles that the library plays and the library gained support for its services. Library staff learned how deeply and in how many ways the public values its library.

\section{Relating Library Goals and Priorities to Community Priorities}

Final and crucial elements to consider when developing a political agenda are the community's needs for library services and the goals we have established for service development to meet these needs. Controversies provide one opportunity to learn about the community's needs and the roles the community wants the library to play in serving these needs. A planning process which has involved staff, board, community, and governing officials is a less disruptive way. If the planning process considers the needs of all segments of the community and solicits a broad base of participation in the process, then political support is being established from which to draw during both good and hard times.

Durham conducted a planning process in 1989, following the Public Library Association model, and developed a five year plan for library services. We did not use the process to full advantage to build political support, but did have the very active involvement of the library board and the Friends of the Library, with the result that board and friends members became more effective spokespersons for the library. During the process, we all gained a fuller understanding of what library services the community values and which ones it would like to have developed.
We were then able to establish priorities for service and service development which have guided our budgeting and political efforts for the last three years.

We found during the process that the library had developed a strong base of service, which had emphasized to that point the library's role as a community information and activity center. This role had enabled the library to connect with the diversity of the Durham community. It was a role that the planning group did not want to diminish. It became the consensus of the group, however, that the library should turn its focus in the five year planning period to more traditional and basic services. Goals established related to increasing access to services and improving library facilities, developing library staff to provide the highest quality of service, enhancing reference services, emphasizing popular materials in collection building, expanding services to preschoolers, and increasing public awareness of the library.

Last year's budget experience is illustrative of support that can be gained when a political agenda is developed which is based on an understanding of the library's service strengths, particularly as they relate to those with political power, and a commitment to goals and priorities set by staff, board, and community through a planning process.

The budget objectives were based on goals set through the planning process. We wanted to maintain the library's strong service base as a top priority. Emphasis was placed on restoring the materials budget which had suffered some losses in the previous two budget years and on keeping existing services

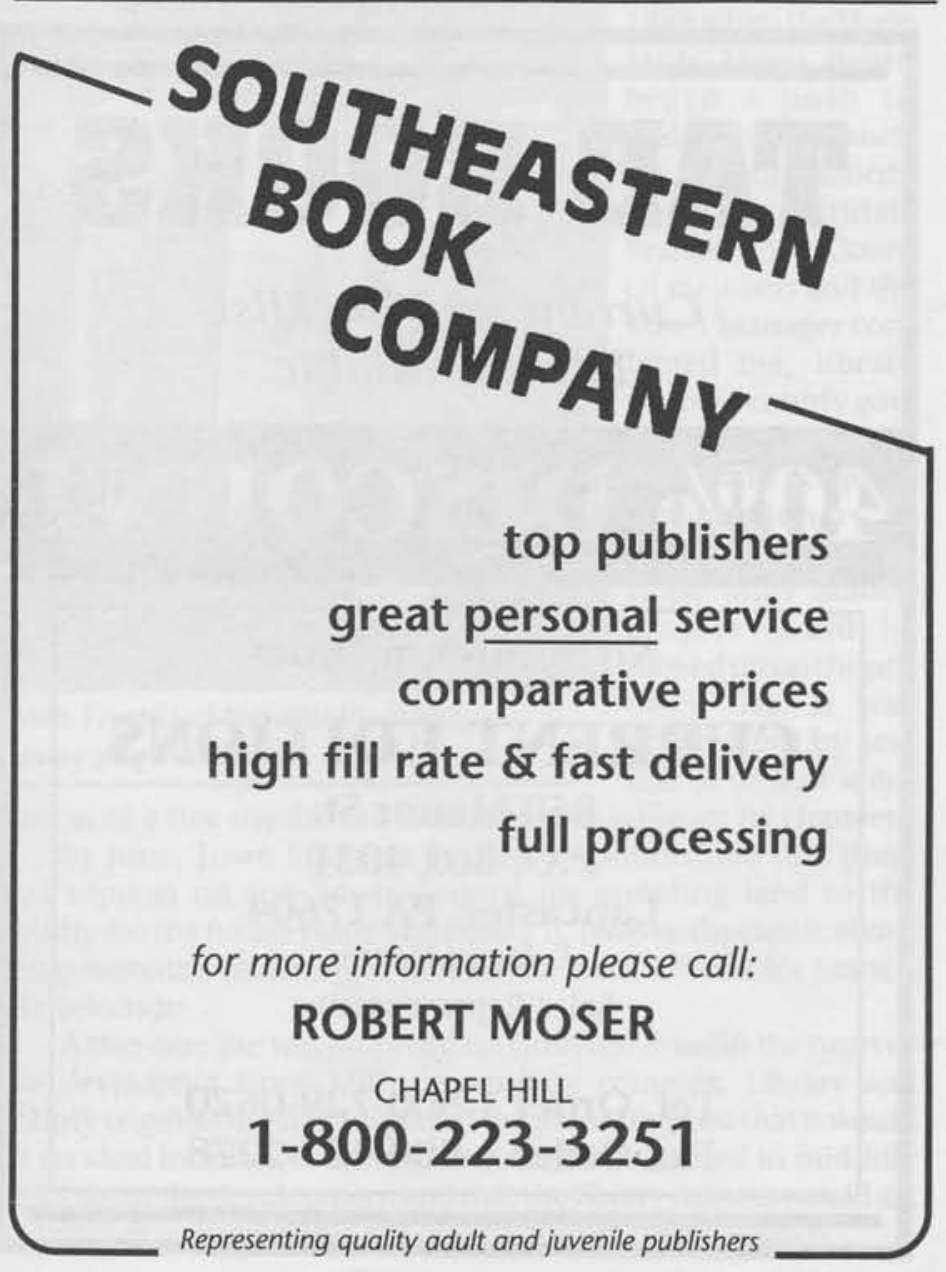


operating at the current levels. We also had an expansion item which the commissioners had approved in concept the previous year: upfit and operational costs of a new branch library, the construction of which was about to go out for bid.

When we were told by the county manager that our budget requests had to be cut below the benchmark, the opening of the branch was jeopardized. Our only alternative in this scenario to delaying the opening was to cut existing services. Although the opening of the branch directly served our goal of increasing access to our services and improving library facilities, there was no support among the staff or board for cutting existing services in order to increase library accessibility. Instead, it was decided to do battle politically to restore the branch operational funds to the budget.

Being aware of the political climate made this decision a relatively easy one. We knew that there was considerable political support for the branch from the community in which it would be located that could be called upon in a budget battle. We also knew that the commission needed support from the community that would benefit from this branch. It was this community that was most unhappy about the prospect of a school merger being advocated by the commission. It was this community that was being most heavily impacted by increasing taxes to pay for increased human service and public protection costs.

Despite this climate that favored our chances for success, we also knew that there was a risk we might lose this battle because of the commissioners' own priorities for the budget year, which emphasized service to low income residents. The population to be served by the new branch was predominantly middle to upper income. Our case was strengthened, however, by the point that the library's basic services, which had received the highest priority from staff and board in the base budget had long emphasized service to lower income areas of the county rather

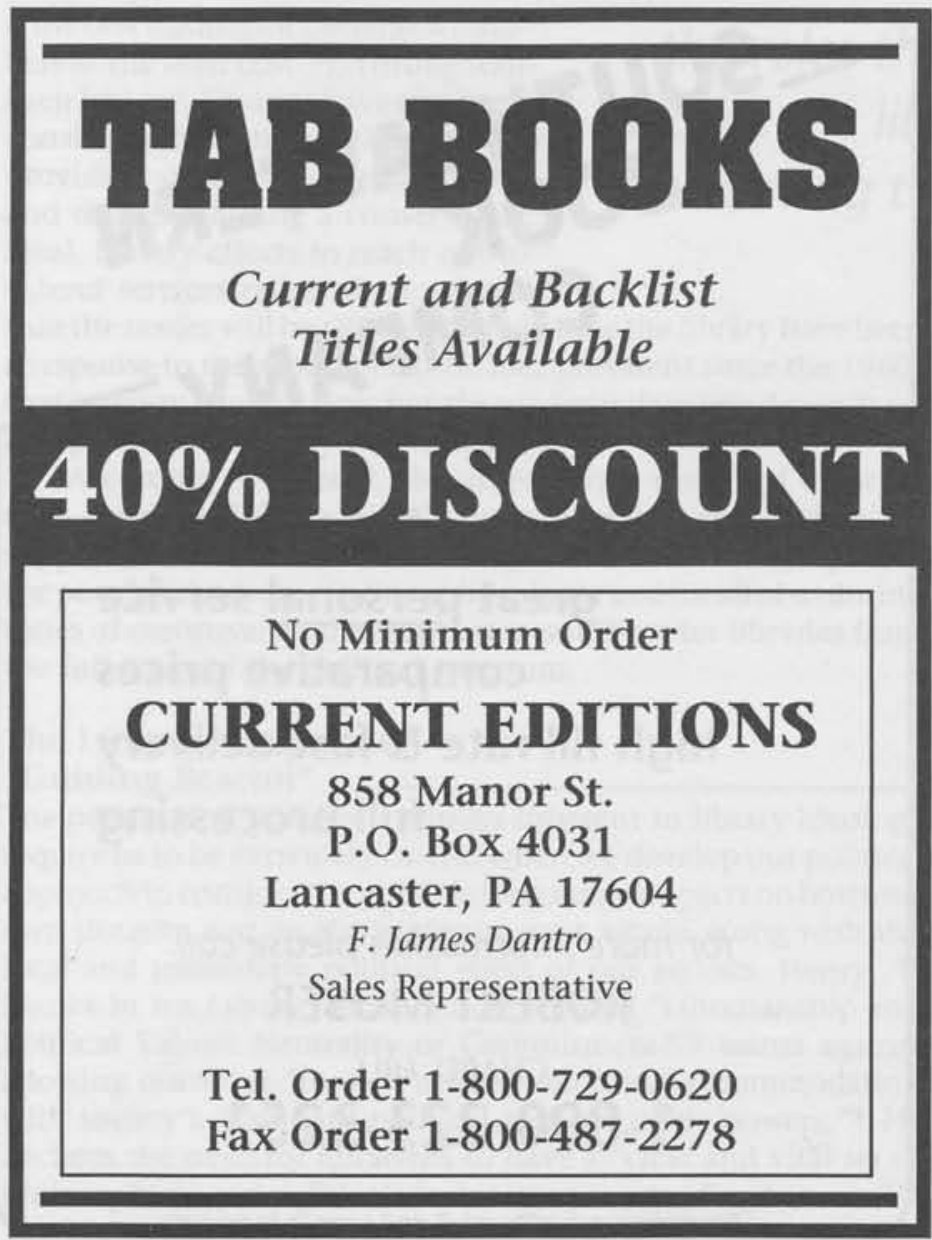

than service to suburban neighborhoods. It was also strengthened by the concern that not funding the branch would cause our operational budget to drop below the prior year's budget, resulting in a potential loss of state and federal aid, severely impacting our basic services.

With the support and guidance of our commissioner liaison, we were able to identify and use our political strengths in this situation. We searched the community to be served by the branch for spokespersons who could impact the vote of each commissioner. With the help of the Friends of the Library, we were relatively successful in getting them to write, call, and come out to the public hearing on the budget. The library board was extremely influential in the lobbying effort, each member using arguments appropriate to the commissioner being addressed. Our commission liaison was almost obstinate in her support for the library during the board's final budget deliberations. Ultimately, the library branch was one of the few expansion items approved by the commissioners. If the library had not had a clear set of priorities and objectives during this process and an awareness of how they related to the political climate, it is likely that the new branch would have been delayed, and possibly even scuttled.

I have attempted in this article to illustrate that libraries can gain support from those with power in a community, even in difficult budget years and during times of controversy. To do so, librarians must stay aware of and cultivate the changing political environment. We must be committed to the ideas we stand for professionally and educate the public as to the relevancy of that ideology to the full diversity of the community. We must also educate ourselves about the ways that the public values the library and touch as many people as we can through our services in meaningful ways. Finally, we must keep the library's mission and goals always in front of us as a guiding beacon for our actions. If we follow these guidelines, we will have developed an effective political agenda.

\section{References}

1David Shavit, The Politics of Public Librarianship. (New York: Greenwood Press, 1986), 24, 63.

2Ibid., 63.

3William F. Birdsall, "The Political Persuasion of Librarianship," Library Journal (June 1, 1988): 75-79.

${ }^{4}$ Ibid., 79.

5Ibid., 77.

6Melvil Dewey, quoted in Paul Dickson, The Library in America, (New York: Facts on File Publications, 1986), 20.

7Birdsall, 79.

8Henry T. Blanke, "Librarianship and Political Values: Neutrality or Commitment?," Library Journal (July, 1989): 39-43.

9Ibid., 39.

10Ibid., p. 42.

Great Expectations/Hard Times What the Dickens Is Happening in Libraries? An NCLA Conference Workshop

Co-sponsored by: The Round Table on the Status of Women In Librarianship and The College and University Section

Thursday \& Friday, (NOON TO NOON) August 6 - 7, 1992.

$\$ 30$ for members $\cdot \$ 40$ for individuals (Includes Wine \& Cheese Reception \& Dinner)

Contact: Karen Seawell Purcell (919) 379-4483/4176 (Round Table) Plummer Alston Jones, Jr. (919) 584-2338 (Section) 


\title{
Faith, Hope, and Politics in Cumberland County
}

\author{
by Jerry Thrasher
}

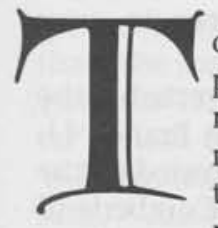

oo often politics is seen as a "dirty" business. But politics is how a democracy functions to bring about needed change. People must lobby their elected representatives to make their needs known and urge that they be met. The most effective means to have needs met by government is for a group of citizens to organize around that need or issue and work together. This is true at the national, state and especially at the local level. As the popular adage states, "all politics is local politics."

The people of the Town of Hope Mills in Cumberland County, North Carolina, were very effective and successful, despite setbacks, in undertaking "positive politics" to push for a new branch library for their community.

The desire for an expanded Hope Mills Branch began in early 1987 when the Hope Mills Town Board proposed that the town would provide land for the new branch library if the Cumberland County Commissioners provided the money for construction. Town ManagerJohn Beasley made a formal presentation to the county commissioners on February 2, 1987, pointing out the growing population of the Hope Mills area and the growing use of the small, inadequate branch library.

At that time Hope Mills had a 1,400 square foot branch library that was located in part of the town hall on Main Street. It was established by Library Director Dorothy Shue in 1960 as part of the Cumberland County Public Library with Library Services and Construction Act (LSCA) funding.

The service population for southwestern Cumberland County was just over 27,000 , and the use of the existing branch had continued to grow at least seven percent a year to over 77,000 book circulations by July 1989 . The branch operated six days a week for a total of 55 hours with two full-time staff.

The Cumberland County Public Library and Information
Center Board of Trustees voted on February 19, 1987, to make the new Hope Mills Branch Library its third priority behind the proposed Cliffdale Branch and the proposed Raleigh Road Branch. The Cliffdale Branch site had just been purchased and construction was anticipated within one and a half to two years.

The Raleigh Road Branch was decided to be second priority because there was no existing branch in that part of the county and there was a greater population base $(34,000)$ than in the Hope Mills area $(27,000)$. It was also pointed out that Hope Mills at least had a small branch facility, whereas residents in the northern part of the county have only periodic bookmobile stops.

After this deci-

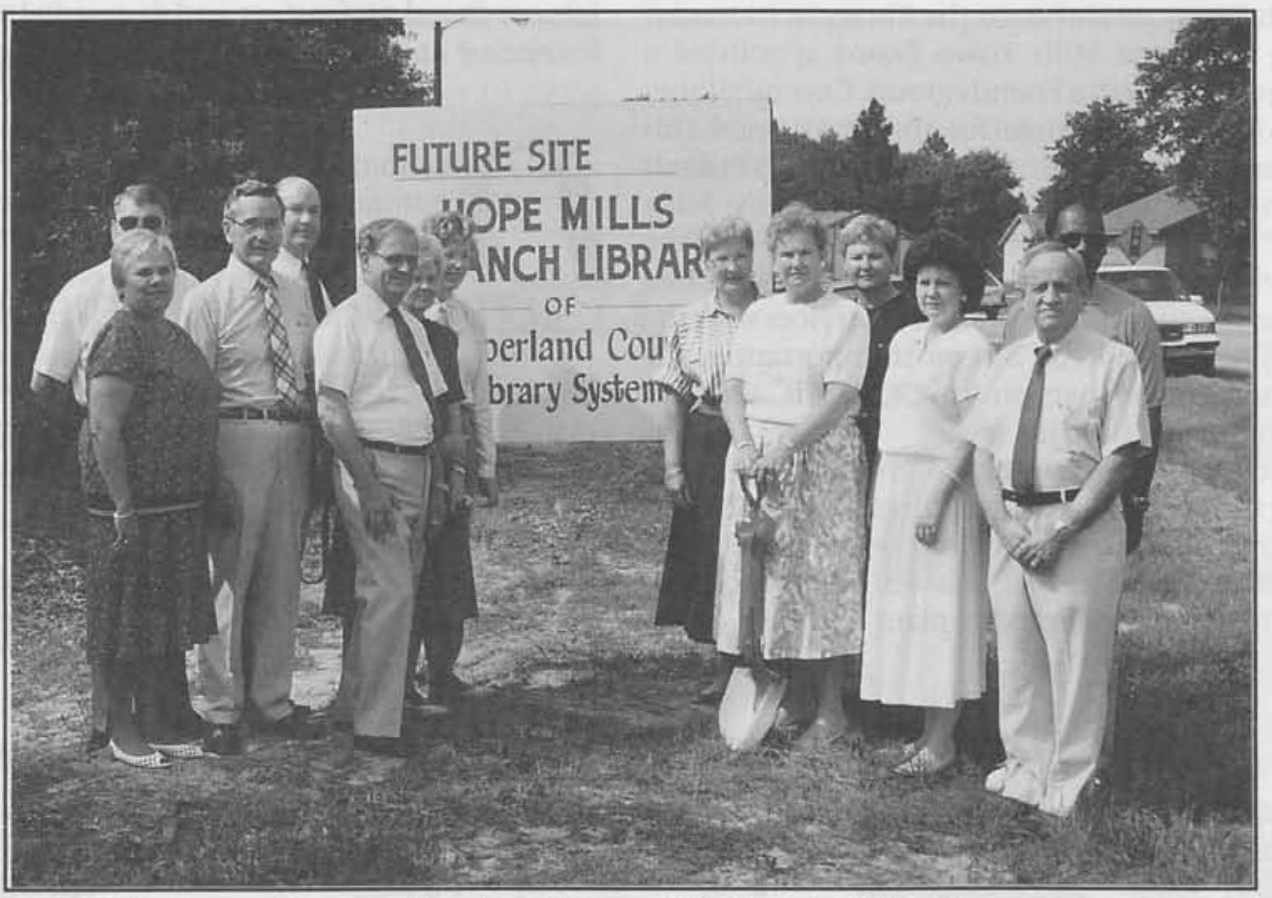

Members of the executive board, Hope Mills Friends of the Library at the construction site, Spring 1991. (Photo courtesy lerry Thrasher.) sion by the library trustees, the issue went on the back burner. The issue resurfaced in early 1988 when the Hope Mills Town Board began a push to make their branch the second priority after the Cliffdale Branch. Town Council members and the Town Manager contacted me, library trustees, county government administration and county commissioners to inquire how the new Hope Mills Branch project could be moved up on the priority list. It was pointed out by several of us that a donation of a free site for the branch would improve its chances.

By June, Town Manager Beasley telephoned me that there was support on the Town Council for donating land to the county for the future Hope Mills Branch. I was enthusiastic about the possibility, assuming it met all our basic criteria for branch site selection.

A two-acre site was proposed on Golfview Road in the heart of the developing Hope Mills community complex. Library and county engineering staff inspected the site and agreed that it would be an ideal location. County government was alerted in mid-July 1988 about the development and that the library trustees would act in favor of accepting this gift of land for the future branch. 
At the library trustee meeting on September 15 , Town Manager Beasley formally proposed donating a two-acre site for the future Hope Mills Branch if the trustees would build a facility of at least 10,000 square feet within three years of acceptance. Of course, the trustees endorsed the proposal, but said that meeting the 1991 deadline would depend on county commissioner approved funding.

The Board of County Commissioners unanimously approved the donation of land at its regular meeting on October 3 to the delight of everyone involved. Of course, library trustees and Hope Mills residents had briefed the commissioners individually about the donation and sought their support. This donation of land was a tangible and popular message of the interest of the Hope Mills community in wanting a new branch library. It helped grease the wheels for a positive decision by the library trustees, county administration and the county commissioners.

The deed for the property was transferred to the county on December 1,1988 . Shortly thereafter, the library trustees made the new Hope Mills Branch Library the second construction priority as part of the library's capital improvements projects in early 1989.

So the Town of Hope Mills had successfully secured the next priority of the library trustees for future branches. The next most important step was securing the needed funding to begin construction.

This story began in January 1989 when representatives of the Hope Mills Town Board met with two library trustees and me to discuss the possibility of setting up a Friends of the Library group "to enhance, nourish, promote and assist the library in its work."

In March 1989 the Hope Mills Town Board appointed a committee of citizens to establish a Friends group. Commissioner Marion Kinlaw was the driving force for the creation of this group. The first organizational meeting of the Hope Mills Friends of the Library was held on March 22, 1989, in the Hope Mills Community Center. Mrs. Dorothy Brower was selected as the group's first president; she was a wise choice. Mrs. Brower had just recently retired as the coordinator for media services with the Cumberland County School System. But most importantly, she had just completed serving six years on the CCPL \& IC Board of Trustees, representing the Hope Mills area.

Mrs. Brower's experience, knowledge, and leadership was a great help in getting the Hope Mills Friends operational. She was able to pull in local community leaders and workers to push for the funding for the needed branch library. She is well known not only as the wife of the retired Hope Mills textile plant manager, but in her school and church involvement. Both she and her husband are alumni of Duke University and active in community affairs. With her numerous contacts she was able to pull together a cadre of dedicated community spirited people to start the Friends of the Library with the help of Town Commissioner Marion Kinlaw.

During the first half of 1989 the Friends held regular meetings getting their bylaws drafted and approved; establishing various committees on membership, publicity, finance, programs and telephoning; and getting incorporated. The official organizational meeting was held on September 25, 1989. At that time they had 117 members and a treasury of just over $\$ 1,800$. goal:

One of the Friends' handouts emphasized their immediate

The purpose of the Friends is to ensure that the library is built by the county on time (Keep in mind that while the library is scheduled to be constructed, no funds have as yet been allocated); and then to enhance the library in every possible way after it is built.

In August, the Friends commissioned a sign to be erected at the future branch site stating "Future Site, Hope Mills Branch Library" to keep the community informed and interested in the project. In February 1990, the Friends invited the Cumberland County Commissioners to have breakfast at the existing Hope Mills Branch Library to see the cramped conditions and the need to move forward with the new facility.

In developing the library's budget in early April for 1990-91, I included $\$ 550,000$ for the first year's construction cost for the new Hope Mills Branch. This was endorsed and approved by the Library Board of Trustees and forwarded to county government for review and recommendation to the county commissioners.

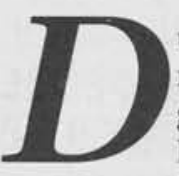

ue to tight budget constraints the county manager did not include the new branch in his recommended budget to the commissioners in May. The Hope Mills Friends began sending word to their members through their newsletter and by telephone to contact the county commissioners and urge their support for funding the new branch. At the same time the Friends wrote letters to Congressman Charlie Rose and Senators Jessie Helms and Terry Sanford to support the federal Library Services and Construction Act for the construction of public libraries funding that President George Bush had eliminated.

The elected officials for the Town of Hope Mills were also making their voices known with the county commissioners during

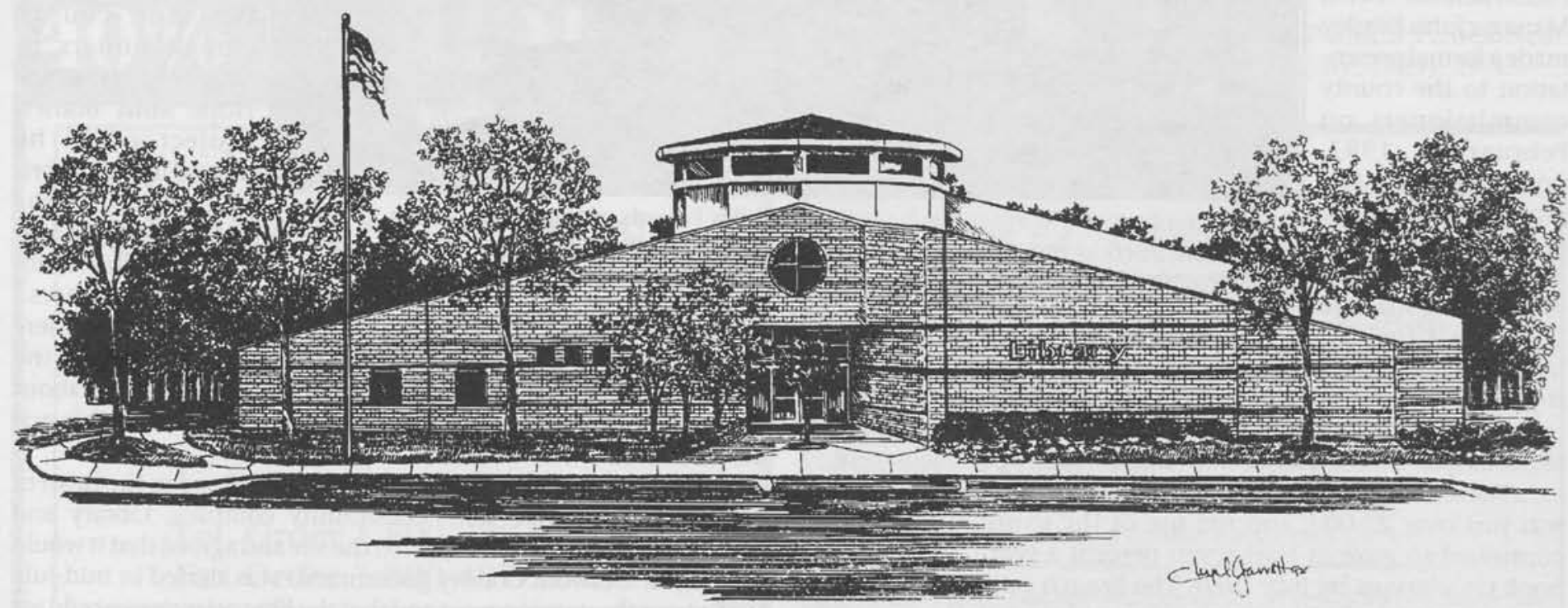

Artist's rendering of the facade of the Hope Mills Branch Library (Cumberland County Public Library and Information Center.) 
this time. This effort culminated on June 14, 1990, during one of the county commissioners' open budget hearings to hear from various county departmental boards. Library Board Chairman Sylvia Dean requested that funding for the new Hope Mills Branch be reinstated. Several members from the Hope Mills Friends were also in attendance showing support for the new branch.

The commissioners requested the county manager to come up with a plan to fund the new branch and increases in library materials without raising taxes. On June 19 , the county manager recommended that a three-month hiring freeze for 106 vacant county government jobs be instituted. This was later expanded to a five-month hiring freeze on all county government positions from July 1,1990 , to December $1,1990$.

One county commissioner was quoted in the local newspaper stating that "the freeze would force cuts in services and called her fellow commissioners' refusal to consider a tax increase a 'bull-headed, short-sighted, myopic attitude.'" Another commissioner said the freeze would hurt many departments, but was needed to build the library without raising the tax rate: "It does create undue hardships on some but we're trying to build a library." 1

In late June the county commissioners approved the required funding in the 1990-91 county library budget to begin construction of the new branch. Like other county departments, the library could not fill three existing positions until December 1990. This was a difficult decision for all concerned because it adversely affected all of county government in order to move forward with this construction project.

The library system was also successful in obtaining an LSCA
Title II construction grant for $\$ 74,179$. Application was made in June 1990. The fact that federal LSCA funding was available through the State Library was an important factor in county commissioner approval of the Hope Mills Branch project.

In July 1990 the architectural selection process was completed and the design phase began. The project went out for bids in January 1991, and construction contracts were approved totalling $\$ 883,688$ in March. The official ground-breaking ceremony was held at the new site on March 28, 1991.

The new 11,200 square foot Hope Mills Branch Library opened its doors on June 6, 1992, thanks to the successful lobbying of the Hope Mills Town Board and the Hope Mills Friends of the Library.

With the dedication and opening of the new branch in June 1992, one of the most successful library lobbying efforts for our library system was concluded. A number of obstacles had to be overcome to make this important project a reality. The Library System's branch priorities were changed; free land was found, donated by the Town of Hope Mills and accepted by Cumberland County Government; a Friends of the Library group was initiated and organized; federal LSCA Title II public library construction funds were applied for; and local county funding for the project was secured during tough economic times. Only the vision and determination of the people of Hope Mills made it happen.

1Bryan McKenzie, "Job Freeze Sought To Fund Library," The Fayetteville Times (June 20, 1990): 4A+

\title{
BROADFOOT'S OF WENDELL
}

6624 Robertson Pond Road

Wendell, NC 27591

Phone: 1-800-444-6963

Locate NC Authors through our now-being-published

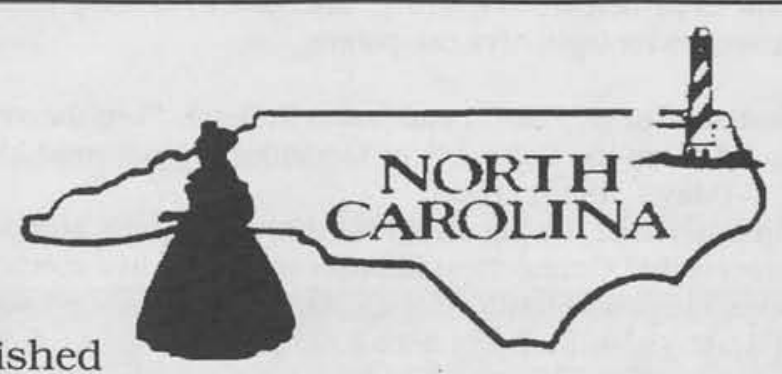

Contemporary North Carolina Authors Packets

\author{
NC BOOKS/AUDIOVISUALS BLACK HISTORY MATERIAL \\ FOR THE YOUNG, OLD, \& IN-BETWEEN \\ Spring \& Fall Catalogs - Are you on our mailing list?
}

Two Different Locations Serving Different Needs

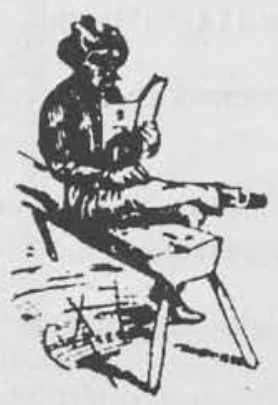

Genealogists \& Reference Librarians Request the Latest Catalog of Source Material from:

BROADFOOT PUBLISHING COMPANY

1907 Buena Vista Circle, Wilmington, NC 28405

Phone: (919) 686-4379 or Fax (919) 686-4379 


\title{
Getting Involved in the Political Process: A Selected Bibliography for Librarians
}

\author{
by John Welch
}

\begin{abstract}
$\boldsymbol{I}$ $\mathrm{n}$ researching articles and monographs for this bibliography, it became apparent that librarians do not write enough about our practical participation in the political process. Many of the periodical citations under the "library - political activities" and "library legislation - political support" headings were short, capsule reports of legislation that had been passed or defeated or recapitulations of the "how to contact your legislator variety." The same is basically true for monographs.

This lack of in-depth practical analysis reveals a weakness on the part of our profession, and it may help to explain why we generally fare so poorly in political terms. We are all affected in some way by political events; thus, our professional journals and literature should reflect our desire to know how political processes work. They also should .amine our political failures and successes. We must research, critique, and write more on our local, state, and national political roles. We must also read and discuss the political process as it is viewed from other disciplines such as political science and economics.

The following bibliographic items offer the reader a variety of approaches to involve libraries in the political process. Readers should pay particular attention to Brettschneider and Benn's article on the legislative strategy of Connecticut libraries and Hall's analysis of the Chesapeake, Virginia, library building campaign. E.J. Josey and Kenneth Shearer's collection of essays is an excellent introduction and overview of the subject.
\end{abstract}

Alderson, George and Everett Sentman. How You Can

Influence Congress. New York: E. P. Dutton, 1979.

A comprehensive, "nuts and bolts" approach to lobbying at the national level, the authors' remarks can also be translated to state and local level political needs. Included in the discussion are letter writing guidelines, how to make effective telephone calls, how to participate in hearings, and how to develop tactics and strategies for legislative campaigns.

Brettschneider, Sharon and James R. Benn. "Legislative

Action: the Connecticut Model". Library Journal 112, 3

(May 1, 1989): 31-36.

An analysis of the planning, legislative program, and political process that Connecticut libraries employed in a special statewide campaign designed to enable the state's citizens to gain full access to library materials. This article could serve as a grassroots training manual for any type of library.

Getz, Malcolm. Public Libraries: An Economic View. Baltimore and London: The Johns Hopkins Press, 1980.

Economics and politics go hand-in-hand in contemporary society. Getz offers an economist's view of how to evaluate library programs and services. Although the book focuses on public libraries, many of the ideas and examples can be applied to the evaluation of other types of libraries, too.

Hall, Richard B. "Winning a Bond Issue for a New Library: The Chesapeake, Virginia, Campaign."Bottom Line 3, 2 (1989): 22-27.

A case study highlighting one library's successful public political campaign. The article focuses on the importance of a carefully thought out political strategy that reaches both voters and politicians.

Hernon, Peter and Charles R. McClure. Evaluation and Library Decision Making. Norwood, New Jersey: Ablex

Publishing Corporation, 1990.

To justify funding requests, libraries need to have a solid understanding of their own services. This work provides spe- cific examples of how to plan, construct, and carry out detailed evaluations of various types of typical library services. There is also a special chapter dedicated to dealing with the political content of any evaluation program.

Ihrig, Alice B. "Librarians and the Political Process." In As Much to Learn as to Teach, edited by Joel M. Lee and Beth A. Hamilton, pp. 83-93. Hamden, Connecticut: Shoe String Press, 1979.

Ihrig argues that libraries themselves should be responsible for taking the lead in any political process.

Josey, E.J. and Kenneth Shearer, eds. Politics and the Support of Libraries. New York: Neal-Schuman Publishers, Inc., 1990. An eminently readable selection of essays by nationally known librarians, this volume encompasses federal, state, and local political arenas. Especially read U.S. Representative Major Owens's article (pp. 23-31) on the federal congressional process and David Shavit's essay (pp. 87-94) on the politics of state budgeting.

Machiavelli, Niccolo. The Prince. New York: Viking Penguin, 1961.

Machiavelli's observations on power and politics are well established. When set in the context of current political environments, his insights still prove true to life.

Mason, Marilyn Gell. "Politics and the Public Library: A Management Guide." Library Journal 114, 5 (March 15, 1989): 27-32.

The public library's political position as viewed from the library director's chair.

Roper, William, L. Winning Politics: A Handbook for Candidates and Campaign Workers. Radnor, Pennsylvania: Chilton Book Company, 1978.

How do aspiring as well as established politicians organize and run their campaigns? When and where can libraries insert themselves into a candidate's platform? This work offers detailed insights into the anatomy of a political campaign. 


\section{Librarians, When your library needs children's books, why not consult with a specialist?}

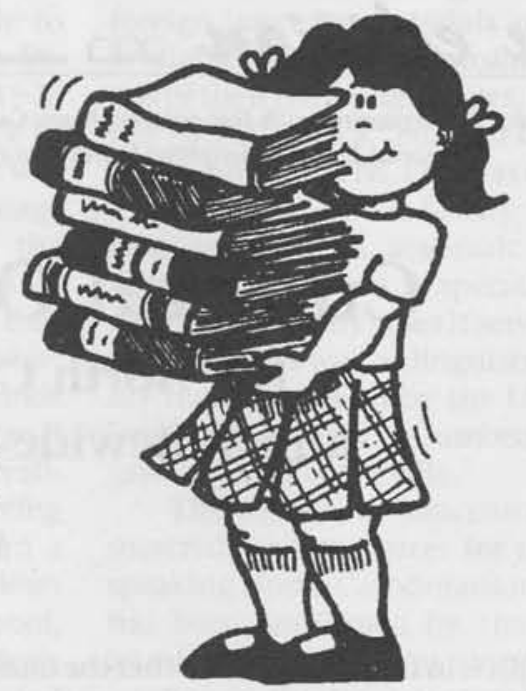

At Book Wholesalers, we specialize in supplying libraries with

children's books. We are large enough to supply you with every children's book you need - yet small enough to offer you personalized, dedicated service. Quite simply, we work with you to make sure you will never have to worry about children's books again.

\section{We offer you:}

- One source ordering

- Triple checks on all orders

- 30 day delivery or status report of order guaranteed

- Subject listings of books

- Customized paperwork

- Standing order plan

- Representative visits to your library to assure great service

- Electronic ordering: convenient toll-free ordering by FAX, telephone or computer

\section{Our goal is to delight you with our service.}

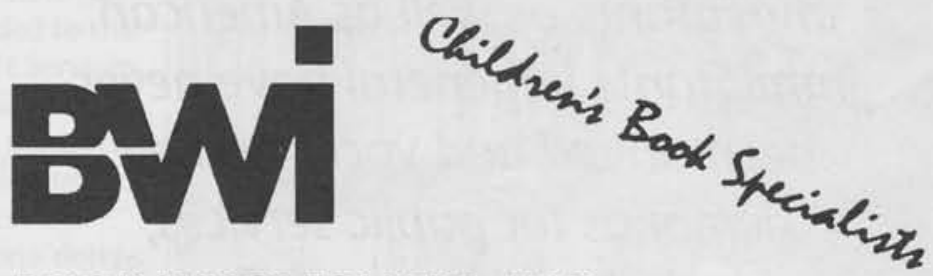

BOOK WHOLESALERS, INC.

2025 LEESTOWN RD. / LEXINGTON, KY. 40511 600/213-9789, 1-800/888-4478, FAX 1-800-888-6319

Contact us today and speak with one of our representatives about how we can end your worries when ordering children's books! 


\title{
Cultural Oasis or Ethnic Ghetto? The North Carolina Foreign Language Center and Statewide Multilingual Public Library Service
}

\author{
by Plummer Alston Jones, Jr.
}

\begin{abstract}
[I] $t$ is in the interest of neither the immigrant nor the rest of the population to obscure the fact of immigration. Except for refugees from persecution, immigrants come by choice and should want to integrate as much as possible into their new country. This means also that within a reasonable number of years immigrants must learn to use the normal library services available to all taxpayers. To institute completely parallel library resources would create ethnic ghettos rather than what I like to call cultural oases.
\end{abstract}

- Leonard Wertheimer (1987)

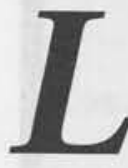

eonard Wertheimer, throughout his distinguished career and even after his retirement in 1979 as Languages Coordinator for the Metropolitan Toronto Library Board, spoke and wrote with understanding of, and compassion for, theplight of immigrants. The leading quotation, excerpted from his remarks made to the Working Group on Library Services to Ethnic and Linguistic Minorities of the International Federation of Library Associations (IFLA), reflects that rare blend of the philosophical and the practical which is typical of Wertheimer's wisdom and advice.

Always demanding quality and parity in public library service to immigrants and ethnic minorities, Wertheimer was quick to admonish librarians, particularly in their zeal to meet immigrants' informational and recreational needs, to maintain "a sense of proportion" and to set clearly defined "parameters and limits" for multilingual library services. Wertheimer warned that to deny or forget the fact of choice, implied by immigrants themselves in the decision to immigrate, might lead to the establishment of library services strictly for immigrants, or ethnic ghettos, rather than library services promoting intellectual and cultural exchange between immigrants and the native-born population, or cultural oases. ${ }^{1}$

The philosophical and practical decisions behind the creation of the North Carolina Foreign Language Center (NCFLC) in 1976 and the development of this multilingual public library over the past sixteen years together manifest an agreement with the philosophy of multiculturalism and good common sense which Wertheimer espoused consistently and eloquently. Studying the history of the NCFLC, including a description of its resources and services and an analysis of recurring issues and trends affecting its overall operations, will answer the question posed initially: Has the NCFLC become a cultural oasis for all North Carolinians or an ethnic ghetto only for immigrants to North Carolina?

A closer look at the distribution of the immigrant population of the United States in general illuminates the demographic situation facing the public library community

\section{Indeed, North Carolina} immigrants as well as American immigrants in general have never been united and vocal in their demands for public services, including library service.

in North Carolina in the late 1970s. In terms of gross numbers of immigrants and the percentage of these immigrants as compared to the total population, immigrants have traditionally represented only a fraction of the population of potential library users in the South, generally, and in North Carolina, specifically. For example, during the period from 1870 to 1970 , the foreign born (i.e. those residents of the United States born elsewhere) in the South repre- sented approximately 2 percent of the total population; in the Midwest, approximately 12 percent; in the West, approximately 12 percent; and in the Northeast, approximately 18 percent. ${ }^{2}$

It is apparent, then, from these demographics that the NCFLC was not established to meet a hue and cry from a large immigrant community in North Carolina. Indeed, North Carolina immigrants as well as American immigrants in general have never been united and vocal in their demands for public services, including library service. Rather, the NCFLC was formed in 1976 in response to a Federal guideline for the administration of funds awarded the North Carolina State Library under Title I of the Library Services and Construction Act (LSCA). Among many appropriate uses of Title I LSCA funds, one guideline suggested that a portion of the overall funds should be allocated for the provision of library materials and services for nonEnglish-speaking taxpayers. ${ }^{3}$

Recognizing non-Englishspeaking immigrants to North Carolina as a small, but nevertheless underserved population, the North Carolina State Library, the state agency responsible for the administration and allocation of Title I LSCA funds, demonstrated farsightedness in transforming this guideline into a reality. Ironically, while the North Carolina General Assembly has never allocated funds to the State Library for the provision of public library service to non-English-speaking North Carolinians, the State Library has never waivered since 
1976 in its commitment to allocating a substantial portion of Title I LSCA funds for this purpose. State Library officials considered several options for the initial use of the LSCA funds thus allocated for multilingual public library service, at least three of which were seriously debated. 4

The first option was to find a central urban location where the majority of the State's non-English speakers would have convenient walk-in access. Variations on this pattern of placing resources in urban centers where immigrants are concentrated has been traditional in other areas of the United States, particularly in the Northeast and Midwest where the majority of immigrants have settled. A study of the distribution of the immigration population of North Carolina based on the 1970 census revealed that, while the majority lived in the three large counties of Cumberland, Mecklenburg, and Wake, there were pockets of immigrants scattered across the state. For this reason alone, many other states with no densely populated urban centers had chosen their respective state libraries as the logical place for the centralization of foreign language resources, but, due to the overcrowded conditions at the North Carolina State Library in Raleigh, this alternative was not viable.

A second option called for the establishment of a cooperative network of institutions interested in offering multilingual public library service. This option would have scattered limited LSCA funds among the larger urban counties and almost assured that available funds would have had to be spent for foreign language materials exclusively. Very little money would have remained for the employment of staff adept at handling these materials and with working with non-English-speaking library users. Duplication of materials would have resulted throughout the state and, in most cases, administration of these new services would have been either added to the work loads of already taxed Adult Services librarians and Interlibrary Loan librarians, or assigned to other library staff members with neither the expertise nor predeliction to provide multilingual library service.

The third option, and the one determined to be most feasible and viable, was not only to centralize library resources and services in a location already serving a large immigrant population, but also to make them available on a statewide basis to all types of libraries through interlibrary loan. State Library officials in Raleigh were aware that the Cumberland County Public Library \& Information Center (CCPL\&IC) in Fayetteville, located about sixty miles to the southeast, had recently used a 1975 LSCA grant in the amount of $\$ 7,500$ to purchase library materials in Vietnamese for an established and grow- ing multilingual collection.

Affirmative overtures were made to David Warren, then CCPL\&IC Library Director, who agreed to use the initial 1976 Title I LSCA grant for this new service in the amount of $\$ 88,000$ to begin what was called at that point the Foreign Language Project. Four years later, in 1979, the name was changed to the North Carolina Foreign Language Center to reflect that services as well as resources were available. These initial and subsequent LSCA funds would be used to purchase multilingual library materials and to make them available on a local basis to library users living in the environs of Fayetteville and on a statewide basis through interlibrary loan to library users of public, high school, college, university, community college, church, and other special libraries located across North Carolina. 5

It might have appeared that an "ethnic ghetto" was in the making had it not been for a policy decision to make these multilingual resources and services available not only to immigrants, who desired materials in their native tongues or resources for learning English as a second language, but also to English-speaking North Carolinians, who desired to learn to read and/or speak foreign languages. To this end, the NCFLC has three goals: (1) to acquire and provide recreational library materials for residents of North Carolina who desire materials in non-English languages; (2) to acquire and provide materials for learning English as a second language (ESL); and (3) to provide language learning materials for residents desiring to gain foreign language skills. 6
This fundamental agreement to make foreign language materials and resources available to all North Carolinians, regardless of their native languages, transformed the NCFLC into a "cultural oasis." Most importantly, the NCFLC was conceived as a multilingual public library; it was never envisioned as an academic or research library, or even as a special collection, although in many cases it serves educators at all levels as well as linguists, most notably those stationed by the U. S. Army at Fort Bragg, located in Cumberland County just outside Fayetteville. ${ }^{7}$

The wisdom of concentrating library materials and resources for non-Englishspeaking North Carolinians in the NCFLC has been reaffirmed by changes in the immigrant population since 1976. According to the 1980 census, for example, there were 129,168 ( 2.2 percent) of a total of $5,881,766$ North Carolinians who spoke a language other than English at home. From 1978 to 1988 , an average of 3,300 immigrants to the United States chose North Carolina as their home (see Chart 1). During fiscal year $1987 / 88$, for example, North Carolina received 3,777 immigrants representing .6 percent of the total of 643,025 immigrants to the United States. Of these immigrants to North Carolina, 50 percent were from Asia, approximately 12 percent from Europe, 11 percent from North America, and approximately 2 percent from South America (see Chart 2). 8

Although the NCFLC has never been overstaffed and has had five coordinators in its sixteen years, the staff has remained exceptionally responsive to immigration

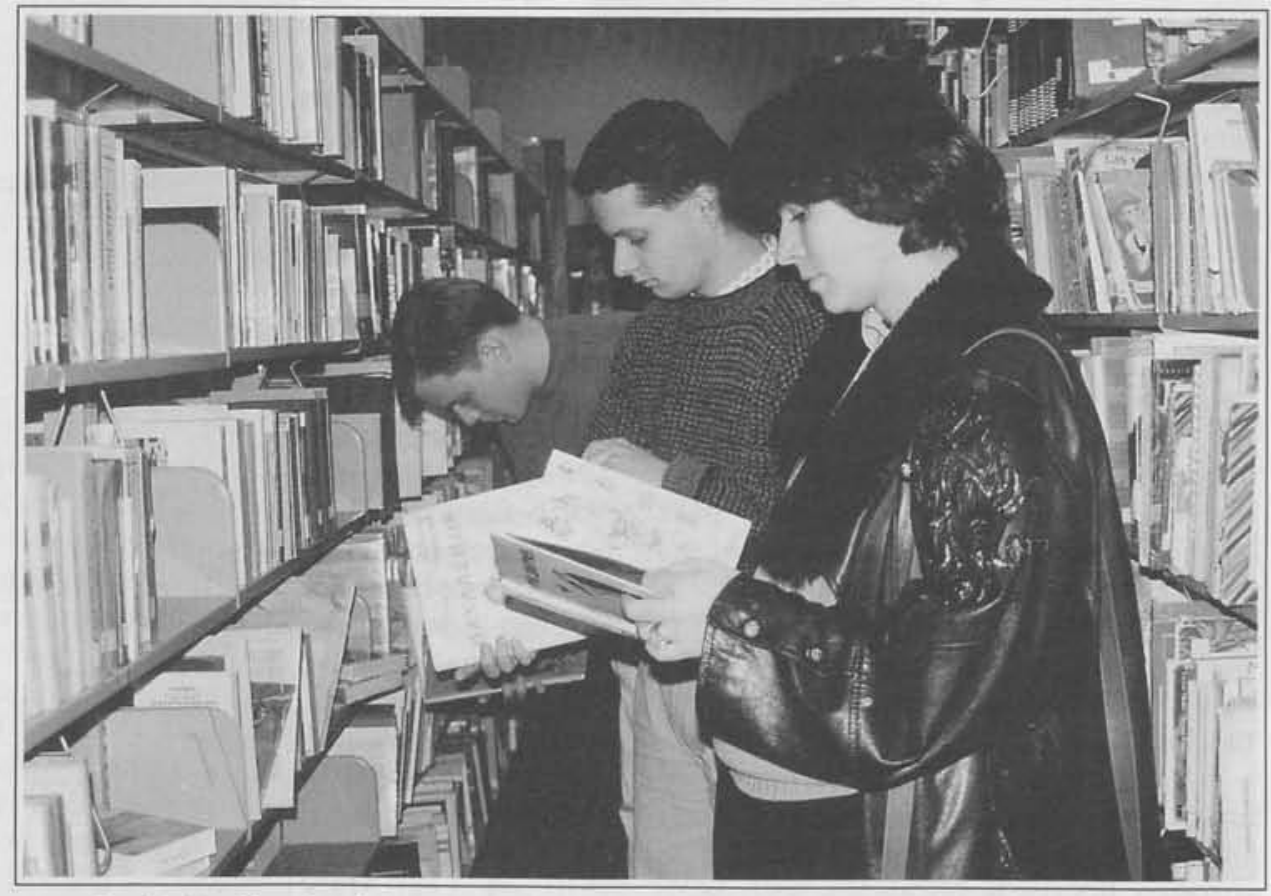

North Carolina Foreign Language Center offers a Russian Collection for Russian students. (Photo courtesy Frank Newton.) 


\section{Chart 1}

IMMIGRANTS TO NORTH CAROLINA, FISCAL YEARS 1977/78-1987/88

$\begin{array}{ll}1978 & 3,036 \\ 1979 & 3,004 \\ 1980 & \text { Not available } \\ 1981 & \text { Not available } \\ 1982 & 3,200 \\ 1983 & 3,494 \\ 1984 & 3,207 \\ 1985 & 3,151 \\ 1986 & 3,317 \\ 1987 & 3,181 \\ 1988 & 3,777\end{array}$

Source: United States. Department of Justice. Immigration and Naturalization Service. Statistical Yearbook of the Immigration and Naturalization Service, 1988. Washington, DC: U. S. Department of Commerce, National Technical Information Service, 1989, Table 17: "Immigrants Admitted, by State of Intended Residence, Fiscal Years 1978-88," 35.

trends for the United States generally, and for North Carolina specifically. The responsiveness of its leadership is manifested in the NCFLC's publicity campaigns and involvement in local, regional, and state educational and cultural endeavors, in its acquisitions and collection development strategies, and in the services it provides (see Chart 3 ).

The first coordinators of the NCFLC, Robert Ivey and Deborah Iannitto, concentrated efforts during the late 1970 s on publicity for the unique and, even by today's demanding standards, innovative services offered to all North Carolinians. Ivey printed brochures in various foreign languages and Iannitto started the NCFLC Newsletter, including short-titleannotated bibliographies of holdings in selected foreign languages, which was mailed to libraries and educational institutions throughout North Carolina and to selective institutions in the Southeast, principally state libraries.

With the advent of Patrick Valentine as coordinator in the early 1980 s, the mailing list for the NCFLC Newsletter more than doubled. A microfiche catalog of the collection was produced and sent free-ofcharge in 1982 to all institutions on the mailing list, followed three years later by an updated 1985 edition of the microfiche catalog.

Valentine was particularly effective in articulating the mission and publicizing the resources and services of the NCFLC through library publications with both national and international readerships. The publicity derived from these publications was complemented by that gained through talks and exhibits with state educational organizations, including the Foreign Language Association of North Carolina (FLANC), and the North Carolina Association of Teachers of English as a Second Language (NCA TESOL). ${ }^{9}$ At the local level, the NCFLC began and continues a tradition of having displays and sponsoring a foreign language book sale at the Fayetteville International Folk Festival and assisting language learning classes from nearby Fort Bragg on a regular basis. 10

In 1979, the NCFLC was included in a nationwidesurvey of public library services to ethnolinguistic minorities, which demonstrated that the NCFLC, only three years after its founding, was clearly the leading - in fact, the only - public library providing foreign language materials on a statewide basis. 11 By 1984, an educator from Kentuckylauded the NCFLC as "North Carolina's well-kept secret," particularly for its provision of foreign language resources for school systems from rural Bladen County to urban Forsyth County. ${ }^{12}$ The continuing importance of this service to foreign language classes throughout North Carolina was revealed in the statistic that, during the fiscal year $1988 / 89$, 123,605 North Carolina public school students were enrolled in foreign language classes in Spanish, French, Latin, German, Russian, and other non-English languages. 13

Under the leadership of Lee Alan Krieger and Moses Chan, resources and services of the NCFLC

\section{Chart 2}

Europe were further strengthened. Although the NCFLC has from the very beginning been responsible for cataloging foreign language audiovisual materials, the State Library Processing Center staff cooperated initially by providing cataloging for foreign language books. During the tenures of Krieger and Chan, when the Processing Center was

NUMBER AND PERCENTAGE OF IMMIGRANTS TO
NORTH CAROLINA, BY CONTINENT AND BY COUNTRY
N=3,777
FISCAL YEAR $1987 / 88$

\begin{tabular}{lrl}
\multicolumn{1}{c}{ Asia } & & \\
Cambodia & 109 & $(2.9 \%)$ \\
China, Mainland & 113 & $(3.0 \%)$ \\
Hong Kong & 31 & $(0.8 \%)$ \\
India & 338 & $(8.9 \%)$ \\
Iran & 90 & $(2.4 \%)$ \\
Korea & 343 & $(9.1 \%)$ \\
Laos & 117 & $(3.1 \%)$ \\
Lebanon & 44 & $(1.2 \%)$ \\
Pakistan & 46 & $(1.2 \%)$ \\
Philippines & 186 & $(4.9 \%)$ \\
Taiwan & 75 & $(2.0 \%)$ \\
Thailand & 89 & $(2.4 \%)$ \\
Vietnam & 309 & $(8.2 \%)$
\end{tabular}

1,890

$(50.0 \%)$

Germany, West $213 \quad(5.6 \%)$

Ireland $29 \quad(0.8 \%)$

Poland $46 \quad(1.2 \%)$

United Kingdom $177 \quad(4.7 \%)$

\begin{tabular}{lrlrl}
\multicolumn{2}{c}{ North America } & & 413 & $(11.0 \%)$ \\
Canada & 197 & $(5.2 \%)$ & & \\
Cuba & 3 & $(0.1 \%)$ & & \\
Dominican Republic & 7 & $(0.2 \%)$ & & \\
El Salvador & 10 & $(0.3 \%)$ & & \\
Guatemala & 10 & $(0.3 \%)$ & & \\
Haiti & 21 & $(0.6 \%)$ & & \\
Jamaica & 27 & $(0.7 \%)$ & & \\
Mexico & 138 & $(3.7 \%)$ & & \\
$\quad$ South America & & & 80 & $(2.1 \%)$ \\
Colombia & 44 & $(1.2 \%)$ & & \\
Guyana & 14 & $(0.4 \%)$ & & \\
Peru & 22 & $(0.6 \%)$ & & \\
$\quad$ Other ${ }^{1}$ & 929 & $(24.6 \%)$ & 929 & $(24.6 \%)$ \\
TOTAL & 3,777 & $(100 \%)$ & 3,777 & $(100 \%)$
\end{tabular}

1The U. S. Immigration and Naturalization Service defines the "Other" category as follows: "Includes nonpreference immigrants, recaptured Cuban number (Silva) immigrants, and those suspension of deportation adjustments, private law adjustments and foreign government official adjustments which are subject to numerical limitations." Source: United States. Department of Justice. Immigration and Naturalization Service. Statistical Yearbook of the Immigration and Naturalization Service, 1988. Washington, DC: U. S. Department of Commerce, National Technical Information Service, 1989, Table 16: "Immigrants Admitted, by Selected Country of Birth and State of Intended Residence, Fiscal Year 1988," 32-34. 


\section{Chart 3}

COORDINATORS OF THE

NORTH CAROLINA FOREIGN LANGUAGE CENTER 1976-

Robert Ivey (July 1976-June 1977)

Deborah lannitto (July 1977-Fall 1979)

Patrick Valentine (December 1979-july 1985)

Lee Alan Krieger (September 1985-August 1989)

Moses Chan (November 1989-january 1991)

VACANCY (February 1991- )

Sources: Letters, Frank Newton, NCFLC, to Jones, Elon College, 24 July 1991, 6 Sept. 1991.

eventually phased out in June 1989, the NCFLC assumed the responsibility for cataloging all materials.

By the late 1980 s, member libraries in North Carolina and throughout the country had access to the NCFLC's holdings through the Online Computer Library Center (OCLC), including selective users in North Carolina who used OCLC for interlibrary loan only through the Local and Intercampus North Carolina Network (LIN.C. NET) promoted by the North Carolina State Library. At the regional level, the NCFLC's foreign language videocassette holdings are available online to users of Western Carolina University's campus information network, MicroNet.14

The NCFLC has from its very inception concentrated on the acquisition of contemporary popular materials in a wide array of print and audiovisual formats. Fiction as well as nonfiction, standard classics, comic books, children's materials, language learning kits, sound recordings (including audio tapes, compact discs, and phonorecords) of music and prose, videocassettes, study prints, grammars, phrase books, dictionaries, and periodicals are available for local use and through interlibrary loan. As of the fiscal year 1990/ 91, the NCFLC owned 42,314 items, including 39,061 books, 1,151 phonorecords, 637 videocassettes, and 1,465 audiotapes and filmstrips. 15

The NCFLC is justifiably proud of its acquisition of materials in over one hundred foreign languages, but also pragmatic in its decision to use limited funds available to purchase materials in the approximately forty to fifty foreign languages spoken by the majority of the immigrants to North Carolina (see Chart 4). In addition, the NCFLC maintains dictionaries, grammars, and selective anthologies of readings in foreign languages which are not aggressively or systematically acquired. The NCFLC subscribes to 53 international magazines and professional periodicals, including 16 in English and 37 in eight other languages. These resources are highlighted in the new and expanded NCFLC Quarterly, the successor to the NCFLC Newsletter. 16
During the fiscal year 1990/ 91, the NCFLC circulated 54,890 items, 52.3 percent through interlibrary loan and 47.7 percent through local circulation. Although interlibrary loan of individual titles is popular and the standard procedure for non-local circulation, the NCFLC also distributes a large portion of its collection throughout the state by means of "deposit collections." In 1990/ 91, for example, the NCFLC sent out 111 deposit collections to 52 libraries in 34 counties. Not surprisingly, urban public libraries in the more populous counties of Mecklenburg, Wake, Guilford, and Forsyth are among the heaviest users of deposit collections. 17

The cataloging of materials in languages which do not use the Roman alphabet has been and continues to be problematic. For many materials in Middle Eastern and South Asian languages, cataloging is not available on a timely basis through OCLC and only substandard romanization of the author and title of materials is available from foreign book dealers. Notwithstanding the help of eager and capable volunteers, the lack of catalogers with a working knowledge in Arabic, Hebrew, and South Asian languages, including the Indic languages, exacerbates the problems entailed in making these materials available in a timely manner to the significantly large proportion of Asian immigrants to North Carolina. A partial solution to the problem with Asian language materials in general has been met, at least for the East Asian languages, including Japanese, Chinese, Korean, and Vietnamese, by contracting with A.S.I.A. (Asian Shared Information and Access), a California-based non-profit organization, for the selection, acquisition, and original cataloging of East Asian materials. 18

These problems associated with cataloging and acquisition of nonRoman-alphabet materials has caused the staff of the NCFLC to question at least annually the need to investigate alternatives, the most viable of which would involve shifting some of the acquisitions, cataloging, and interlibrary loan functions to large public or academic libraries with strengths in foreign language cataloging and collection development. 19 Ironically, back in 1976, this option was one of the three investigated.

The staff of the NCFLC use popu- lation data available from the U.S. Immigration and Naturalization Service and the U. S. Bureau of the Census as well as local circulation and interlibrary loan statistics to point out areas of the collection to be developed from year to year. For example, during the fiscal year 1989/90, Chan called the U. S. Immigration and Naturalization

\section{Chart 4}

COLLECTION DEVELOPMENT LEVELS FOR BOOKS IN 43 NON-ENGLISH LANGUAGES FISCAL YEAR 1990/91

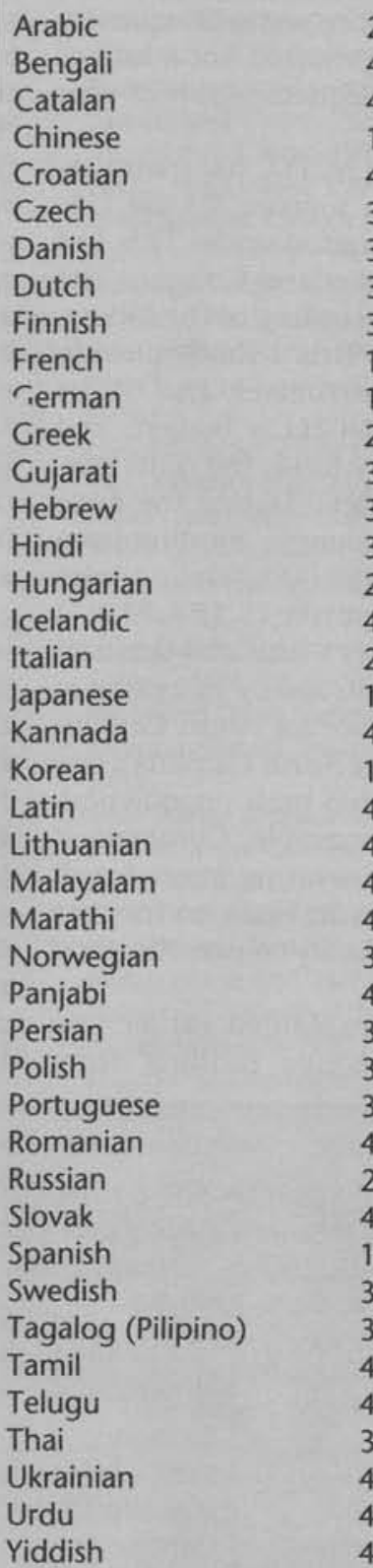

Vietnamese 1

Legend:

1 (large collections of over 1,000 titles)

2 (moderate collections of 500 to 1,000 titles)

3 (small collections of 100 to 500 titles)

4 (representative collections of less than 100 titles)

Sources: NCFLC brochure (Nov. 1988); and Selection Policies for the North Carolina Foreign Language Center (1991). 
Service for advance population data to be used to determine the major non-English languages spoken by North Carolina's immigrants. Using this population data, Chan determined that North Carolina could expect an influx of Asian immigrants speaking one of the numerous Indic languages. This statistic contrasted starkly with local circulation and interlibrary loan data which showed consistently that the top six languages requested were Vietnamese, Chinese, Korean, Japanese, Spanish, and German (see chart 5). The fact that materials in the Indic languages had not circulated well locally and were not requested frequently on interlibrary loan showed not a lack of interest, but an inadequate supply of new materials. 20

Funding for the NCFLC has traditionally been from two sources: (1) the U.S. Department of Education under Title I of LSCA; and (2) Cumberland County. The NCFLC is funded according to the following formula: LSCA Title I funds provide $\$ 150,000$, plus approximately half of the remainder of the NCFLC's budget, and Cumberland County funds the other portion of the remainder. During the fiscal year 1990/91, for example, funding from Title I LSCA was $\$ 169,000$; funding from Cumberland County, $\$ 24,713.21$ Cumberland County's financial commitment to the CCPC\&IC and by extension to the NCFLC, a resource for North Carolinians residing in all of North Carolina's one hundred counties, has been unequivocal. In June 1990, for example, Cumberland County announced a hiring freeze for all county departments in order to increase funding for public library construction and library materials. 22

Ironically, as explained earlier, the NCFLC does not receive funding from

\section{Chart 5 \\ RANKING OF CIRCULATION OF TOP 6 NON-ENGLISH \\ LANGUAGES OR LANGUAGE GROUPS, BY LOCAL USE, AND THROUGH INTERLIBRARY LOAN FISCAL YEAR 1990/91

\begin{tabular}{|c|c|c|}
\hline Rank & $\begin{array}{l}\text { Circulation } \\
\text { Local }\end{array}$ & $\begin{array}{l}\text { Circulation } \\
\text { Interlibrary }\end{array}$ \\
\hline 1 & Korean & Spanish \\
\hline 2 & Japanese & Sino-Tibetan ${ }^{1}$ \\
\hline 3 & Spanish & Southeast Asian² \\
\hline 4 & Sino-Tibetan' & German \\
\hline 5 & German & Japanese \\
\hline 6 & Southeast Asian² & Korean \\
\hline
\end{tabular} \\ 'Includes Chinese and Thai \\ ${ }^{2}$ Includes Vietnamese and Cambodian \\ Source: Annual L.S.C.A. Project Report for the North Carolina Foreign Language Center of the Cumberland County Public Library and Information Center, 1990-1991, Appendix E: "Ranking of NCFLC Circulation by Language, 1990-1991,"12.}

the North Carolina General Assembly. During the 1990/91 legislative session, however, Cumberland County Representative John W. "Bill" Hurley of Fayetteville introduced a bill in the North Carolina General Assembly to provide $\$ 100,000$ in state funding for the NCFLC. 23 Unfortunately, this bill and other educational programs suffered from the tight fiscal situation in North Carolina.

A related budgetary action taken by the General Assembly, which affected the quantity and quality of services in the area of foreign language education, forced county school officials throughout North Carolina to make hard decisions regarding the drastically reduced allocation of Basic Education Program (BEP) funds. The incorporation of foreign language learning throughout the curriculum of some North Carolina public schools was not considered "basic" enough to warrant the limited BEP funds available. 24 Without these state funds, libraries throughout North Carolina will rely more and more on the NCFLC for resources and expertise to fill the void in their respective locales. During periods of tight fiscal control and budgetary restraint, the NCFLC becomes not only a cultural oasis, but also a practical necessity.

On a more positive note, at the federal level, a new Title $\mathrm{V}$ of the LSCA, known as the Foreign Language Materials Acquisition Program, was funded for the 1991/92 fiscal year. Individual libraries throughout the country were eligible to apply for direct grants for the purchase of library materials in non-English languages. The popularity of this new Title $V$ coupled with the realization of the NCFLC's role as the national model for statewide cooperation both became exceedingly apparent when NCFLC reference staff were deluged with requests for information on NCFLC services and resources. Requests were received from personnel at the state libraries of Georgia and Oklahoma as well as public libraries in St. Paul, Minnesota, Princeton, New Jersey, and Providence, Rhode Island, all needing information for their respective Title $\mathrm{V}$ grant proposals. 25

Continuing in this positive vein, Chan of the NCFLC lobbied vigorously at all of the North Carolina Regional Governor's Conferences on Library and Information Services to introduce and gain acceptance for a resolution on behalf of statewide multilingual public library service to take to the 1991 White House Conference on Library and Information Services. Chan was successful in getting the following resolution adopted at the state level:

Resolved: That North Carolina public libraries should expand their services to include programs, materials, and information services and staff expertise necessary to reflect and meet the needs of the state's multi-ethnic society, and all North Carolinians should have access to library materials and information necessary to learn foreign languages as the need for foreign language literacy increases in both the business and personal arena, and the North Carolina General Assembly should allocate state funding for the North Carolina Foreign Language Center's operating budget. The funds should be administered under the direction of the North Carolina Division of State Library. 26

If state funding accrues to the NCFLC as a result of this resolution, Chan will have left a legacy to the NCFLC and the cultural life of North Carolina. The addition of state funding to already existing federal and county appropriations will ensure that the NCFLC will continue to flourish and flower as the cultural oasis envisioned by Leonard Wertheimer.

\section{References}

1Leonard Wertheimer, "Library Services to Ethnocultural Minorities: Philosophical and Social Bases and Professional Implications," Public Libraries 26 (Fall 1987): 98-102.

2United States. Department of Commerce. Bureau of the Census, Historical Statistics of the United States, Colonial Times to 1970, Bicentennial ed. (Washington, D.C.: GPO, 1975), [Table] Series A 172-194: "Population of Regions, by Sex, Residence, Age, and Nativity: 1790 to 1970," 22-23. For more information on library services to the immigrant community provided by the public library systems in other states prior to 1948, see Plummer Alston Jones, Jr., "American Public Library Service to the Immigrant Community, 1876-1948; A Biographical History of the Movement and Its Leaders: Jane Maud Campbell (1869-1947), John Foster Carr (1869. 1939), Eleanor (Edwards) Ledbetter (1870-1954), and Edna Phillips (1890-1968)," Ph.D. dissertation, University of North Carolina at Chapel Hill, 1991, 62-130 passim, and 296-360 passim. See also Thornton W. Mitchell, The State Library and Library Development in North Carolina, with a Foreword and an Epilogue by David N. McKay (Raleigh, N.C.: North Carolina Department of Cultural Resources, Division of State Library, 1983), ix-xii, 6-7.

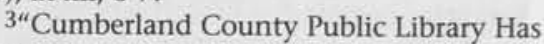
Been Named the Recipient of an \$88,000 Library Services and Construction Act Special Project Grant from the North Carolina State Library," North Carolina Libraries 34 (Fall 1976): 77-78; "Foreign Language Service Launched in North Carolina," Library Journal 101 (1 Oct. 1976): 2000; and letter, Penny Hornsby, Grants Administrator, North Carolina State Library, to 
Jones, Elon College Library, 12 Nov. 1991.

4 Patrick M. Valentine, "The North Carolina Foreign Language Center: A Public Library Service," Public Library Quarterly 5 (Winter 1984): 47-61.

5 Ibid., 53-54; "Cumberland County Public Library Has Been Named the Recipient," 77-78; and "Foreign Language Service Launched," 2000.

${ }^{6}$ North Carolina Foreign Language Center, Annual L.S.C.A. Project Report for the North Carolina Foreign Language Center of the Cumberland County Public Library and Information Center, 19901991, [Fayetteville, N.C.: The Center, 1991], 1. vice," 59

7 Valentine, "NCFLC: A Public Library Ser-

8NCFLC, Anmual Report, 1990-1991, Appendix A: "Number of North Carolinians Speaking a Language Other than English at Home (1980 Census)," 8; United States. Department of Commerce. Bureau of the Census, Statistical Abstract of the United States, 1990 (Washington, D.C.: GPO, 1990), [Table] No. 7: "Immigrants, by Country of Birth: 1961 to $1988, " 10$, [Table] No. 8: "Immigrants Admitted, by Selected County of Birth and Metropolitan Area of Intended Residence: 1988," 10, [Table] No. 9: "Immigrants Admitted, by Selected States of Residence and Country of Birth: 1988," 11; and United States. Department of Justice. Immigration and Naturalization Service, Statistical Yearbook of the Immigration and Naturalization Service, 1988 (Washington, D.C.: U. S. Department of Commerce, National Technical Information Service, 1989), Table 17: "Immigrants Admitted, by State of Intended Residence, Fiscal Years 1978$88, " 35$.

9 Valentine, "NCFLC: A Public Library Service," 53-59. See, for example, the following articles by Valentine, "Multilingual Library Services: Why Bother?," Public Library Quarterly 4 (Winter 1983): 61-63; "North Carolina Foreign Language Center: What It Does, and Why," Unabashed Librarian no. 47 (1983): 19-20; "Minority Language Selection: Helping Ourselves to Help Others," Wilson Library Bulletin (Jan. 1986): 26-29. See also "Foreign Language Center Offers National Access," Library Journal 106 (15 Jan. 1981): 103, and Valentine's rebuttal, "NCFLC Not Nationwide," Library Joumal 106 (15 Apr. 1981): 827.

10 Valentine, "NCFLC: A Public Library Service," 54-55; and letter, Frank Newton, North Carolina Foreign Language Center, to Jones, Elon College, 31 October 1991.

11 Natalia B. Bezugloff, "Library Services to Non-English-Language Ethnic Minorities in the United States," Library Trends 29 (Fall 1980): 259-74.

12 Judi Lawson Wallace, "North Carolina's Well-Kept Secret: The North Carolina Foreign Language Center," Foreign Language Annals 17 (Feb. 1984): 55-57.

13NCFLC, Annual Report, 1990-1991, Appendix B: "Foreign Language Class Enrollment in North Carolina Public Schools, 1988 1989 ," 9.

14Valentine, "NCFLC: A Public Library Service," 56-59; NCFLC, Annual Report, 1989. 1990, 4; letters, Newton, NCFLC, to Jones, Elon College Library, 24 July 1991, and 6 Sept. 1991; and letter, Hornsby, N.C. State Library, to Jones, Elon College Library, 12 Nov. 1991

15NCFLC, Annual Report, 1990-1991, Appendix C: "North Carolina Foreign Language Center Holdings Information," 10; and North
Carolina Foreign Language Center [brochure], [Fayetteville, N.C.: The Center, 1988].

16 NCFLC, Annual Report, 1990-1991, 2-6.

17Ibid., 3-4.

18Ibid., 6-7; and NCFLC, Annual Report, 1989-1990, 2, 5-6.

19NCFLC, Annual Report, 1989-1990, 5-6.

20Ibid., 2-3, and Appendix C: "Immigrants Admitted to North Carolina by Selected Country of Birth in Fiscal Year 1989," 8.

21NCFLC, Annual Report, 1990-1991, 18; and letter, Hornsby, N.C. State Library, to Jones, Elon College Library, 12 Nov. 1991.

22"[Cumberland] County Implements Hiring Freeze to Fund Library Services," Wilson Library Bulletin 65 (Sept. 1990): 11; and letter, Newton, NCFLC, to Jones, Elon College Library, 7 Nov. 1991.

23NCFLC, Annual Report, 1990-1991, 5-6.

${ }^{24} \mathrm{See}$, for example, the situation in Wilson County, "Specialist Is Headed Back to the Classroom," Wilson (N.C.) Daily Times, 14 June 1991; "Education Personnel Cuts To Be Discussed," Wilson Daily Times, 17 June 1991; "Schools Announce Cuts, Reassignments," Wilson Daily Times, 18 June 1991; and "School Cuts Affecting Curriculum," Wilson Daily Times, 21 June 1991. 25NCFLC, Annual Report, 1990-1991, 4, 6.

26 "Citizen and Government Official Resolutions from Eight Regional Governor's Conferences," Tar Heel Libraries 13 (Sept./Dec. 1990): 11-14.

\section{Bibliography}

Bezugloff, Natalia B. "Library Services to NonEnglish-Language Ethnic Minorities in the United States." Library Trends 29 (Fall 1980): 259-74.

"Citizen and Government Official Resolutions from Eight Regional Governor's Conferences." Tar Heel Libraries 13 (Sept./Dec. 1990): 11-14.

"[Cumberland] County Implements Hiring Freeze to Fund Library Services." Wilson Library Bulletin 65 (Sept. 1990): 11.

"Cumberland County Public Library Has Been Named the Recipient of an $\$ 88,000$ Library Services and Construction Act Special Project Grant From the North Carolina State Library." North Carolina Libraries 34 (Fall 1976): 77-78.

"Education Personnel Cuts To Be Discussed," Wilson (N.C.) Daily Times, 17 June 1991.

"Foreign Language Center Offers National Access." Library Joumal 106 (15 Jan. 1981): 103; and rebuttal, Valentine, Patrick." NCFLC Not Nationwide." Library Joumal 106 (15 Apr. 1981): 827.

"Foreign Language Service Launched in North Carolina." Library Journal 101 (1 Oct. 1976): 2000.

Jones, Plummer Alston, Jr. "American Public Library Service to the Immigrant Community, 1876-1948; A Biographical History of the Movement and Its Leaders: Jane Maud Campbell (1869-1947), John Foster Carr (1869-1939), Eleanor (Edwards) Ledbetter (1870-1954), and Edna Phillips (1890-1968)." Ph.D. dissertation, University of North Carolina at Chapel Hill, 1991.

Letters, Frank Newton, North Carolina Foreign Language Center, to Jones, Elon College Library, 24 July 1991, 6 Sept.
1991, 31 Oct. 1991, and 7 Nov. 1991; and Penny Hornsby, Grants Administrator, North Carolina State Library, to Jones, Elon College Library, 12 Nov. 1991.

Mitchell, Thornton W. The State Library and Library Development in North Carolina. With a Foreword and an Epilogue by David N. McKay. Raleigh, N.C.: North Carolina

Department of Cultural Resources, Division of State Library, 1983.

North Carolina Foreign Language Center. Annual L.S.C.A. Project Report for the North Carolina Foreign Language Center of the Cumberland County Public Library and Information Center, 1989-1990. [Fayetteville, N.C.: The Center, 1990].

North Carolina Foreign Language Center. Annual L.S.C.A. ProjectReport for the North Carolina Foreign Language Center of the Cumberland County Public Library and Information Center, 1990-1991. [Fayetteville, N.C.: The Center, 1991].

North Carolina Foreign Language Center. Selection Policies for the North Carolina Foreign Language Center. [Fayetteville, N.C.: The Center, 1991].

North Carolina Foreign Language Center [brochure]. [ Fayetteville, N.C.: The Center, 1988].

"School Cuts Affecting Curriculum," Wilson (N.C.) Daily Times, 21 June 1991.

"Schools Announce Cuts, Reassignments," Wilson (N.C.) Daily Times, 18 June 1991.

"Specialist Is Headed Back to the Classroom," Wilson (N.C.) Daily Times, 14 June 1991.

United States. Department of Commerce. Bureau of the Census. Historical Statistics of the United States, Colonial Times to 1970. Bicentennial ed. Washington, D.C.: GPO, 1975.

United States. Department of Commerce. Bureau of the Census. Statistical Abstract of the United States, 1990. Washington, D.C.: Govt. Print. Off., 1990.

United States. Department of Justice. Immigration and Naturalization Service. Statistical Yearbook of the Immigration and Naturalization Service, 1988. Washington, D.C.: U.S. Department of Commerce, National Technical Information Service, 1989.

Valentine, Patrick. "Minority Language Selection: Helping Ourselves to Help Others." Wilson Library Bulletin (January 1986): 26-29.

Valentine, Patrick M. "Multilingual Library Services: Why Bother?" [North Carolina Foreign Language Center]. Public Library Quarterly 4 (Winter 1983): 61-63.

Valentine, Patrick M. "The North Carolina Foreign Language Center: A Public Library Service." Public Library Quarterly 5 (Winter 1984): 47-61.

Valentine, Patrick. "North Carolina Foreign Language Center: What It Does, and Why." Unabashed Librarian no. 47 (1983): 19-20.

Wallace, Judi Lawson. "North Carolina's WellKept Secret: The North Carolina Foreign Language Center." Foreign Language Annals 17 (Feb. 1984): 55-57.

Wertheimer, Leonard. "Library Services to Ethnocultural Minorities: Philosophical and Social Bases and Professional Implications." Public Libraries 26 (Fall 1987): 98-102. 


\title{
Taking the Political Process on Its Own Terms: Hire a Lobbyist
}

\author{
by Edward Sheary
}

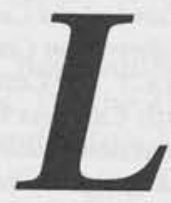

ong-term Speaker of the California House of Representatives, "Big Jess" Unruh, coined the phrase, "Money is the mother's milk of politics." I posit that money is also the mother's milk of libraries and that money is reason enough for our profession to take an active interest in politics. Virtually all of our funding is a direct result of the political process. In light of the intimate connection between politics and library funding, I propose that the North Carolina Library Association get serious about making libraries active players in the political game. Let's do something really bold, really political, perhaps, really unprofessional: let's hire ourselves a professional lobbyist.

This is not a new idea. The Georgia Library Association has been so represented for many years, and, virtually every trade and professional association that I know of has representation in Raleigh. We have discussed it. In 1965, NCLA engaged a legislative counsel to work with North Carolina government officials and others on behalf of improving libraries in the state. Three years ago, the North Carolina Public Library Directors Association actually voted to enter into negotiations with NCLA on this issue. The question was sidetracked early on when the subject of paying for it came up.

Why a lobbyist? The word itself has "high negatives" in the current parlance. Lobbyists are usually referred to by such obfuscating terms as "Legislative Counsel." Further, most librarians do not see themselves as having much to do with politics. As professionals, we tend to forget where our paychecks come from, and we don't look much further than our own institutional contexts: county government, university, community college, or public school systems. Do we as librarians really have enough in common to formulate legislative goals that would be of interest to more than one NCLA section?

I think there is enough common interest to justify a serious NCLA legislative program. Almost all of us receive some part of our funding from the General Assembly, and all of us are subject to the sometimes capricious actions of our legislators. A recent example was the well-intentioned effort to have the Library Bill of Rights written into the statutes. House Bill 473 as introduced contained the phrasing "Public libraries shall provide materials and information presenting all points of view on current and historical issues." The word "shall" in the bill is a bit different than the "should" in the original, especially when we are talking about making law. Fast action by some observant librarians got the wording changed; still, the bill vanished when it was inexplicably sent to the Appropriations Committee. The case of the disappearing bill illustrates the need for a lobbyist. Somebody knowledgeable about library issues who is known by the legislators and recognized as an authority must be on the legislative scene regularly. Our State Librarian is constrained by his position from taking a visible role in advocacy with legislators, and we practitioners are scattered across the state with little information about what is going on in the General Assembly. This is why we need a library lobbyist.

A structure that could support this is outlined by Howard McGinn in the Winter 1991 issue of North Carolina Libraries. There is little that I could add to the compelling case that he makes for the revitalization of NCLA. The lobbyist will not make legislative policy for us. NCLA would have to develop an effective structure for formulating legislative policy. The lobbyist can assist in coordinating initiatives and presenting them as a unified LIBRARY legislative program. It would be up to us to iron out our differences and agree on proposals that would benefit some or all of the constituencies of NCLA. The lobbyist would be our eyes and ears in the General Assembly. We would still have to provide the ideas and the voice.

Good lobbyists are not cheap. The retainer could be $\$ 20,000$ per session. We would be buying legislative expertise and an established reputation for providing reliable information among legislators. Lobbyists do not thrive in Raleigh simply because they throw good parties and make hefty campaign contributions. Most do neither. They succeed or fail on the basis of providing timely and accurate information to legislators. Employing a lobbyist would allow us to concentrate our energy on building grassroots support for libraries. Hiring a lobbyist will not require less work and commitment from us - it will require more. However, we could expect increased effectiveness in getting our points across to those who hold the purse strings. 


\title{
Making an Issue of Library Support: Use the Ballot
}

\author{
by Harry Tuchmayer, Column Editor
}

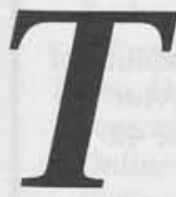

here's a mass political revolt brewing in this country, and I for one would hate for the North Carolina Library Association to find itself allied with the corrupt and decadent features of the ancien régime. Just as we are beginning to recognize the importance of political activism, it would be a terrible mistake to follow in the footsteps of Tammany Hall and Mayor Daley. It's not that Ed is wrong to call for political involvement; in fact, he is to be applauded for his bold support of an idea whose time has come. It's just that his notion of using a lobbyist to accomplish what we should, and must, be fostering on a local level, is all wrong. In short, using a lobbyist won't get us anything other than a tarnished reputation.

The fact of the matter is, most lobbyists are "disreputable-looking types" interested in nothing other than manipulating the system for the good of their paying clients. Why settle for this type of "paid support" when we already command widespread and virtually universal support among the citizenry? The issue isn't whether or not we should try to influence the legislature - by all means let's do that! Rather, the question is how to do it without becoming part of the problem. People are sick and tired of politics as usual and are ready to voice their support for things that matter - and libraries matter!

Now, how do we translate this nebulous support into a tangible force no legislator would be willing to tangle with? Perhaps it's time to revamp such groups as the Friends of the Library into something more than just volunteer and fund-raising organizations. Restructure these bodies into a potent political voice that takes every opportunity to push for increases in library funding. Reorganize their committees, and make one, stacked with the most prominent and well-known members of the Friends, responsible for personally contacting local and state officials on a weekly, if not day-to-day, basis. In short, become so visible on a local level that our elected officials will want, and need to play to this constituency.

There are many other ways to build grassroots support (and with so many baby boomers around I'm sure one of them can remember how to organize a "movement"). The point is, library users, of which there are hundreds of thousands in North Carolina alone, represent the key to influence over all our funding agents. These people, the day-to-day users who value and benefit from library services, need to make library issues a voting priority. If politicians know that people vote based on how libraries fare in a legislative session, we won't need lobbyists, we'll need social secretaries to keep our calendars free for all the parties we'll be

People are sick and tired of politics as usual and are ready to voice their support for things that matter — and libraries matter! - Tuchmayer

\section{Do we as librarians really have enough in common to formulate legislative goals that would be of interest to more than one NCLA section?}

- Sheary invited to!

Unfortunately, legislators don't always vote for, or sponsor, bills they believe in. They vote for things that will get them votes! When fifty people show up at a county commission meeting in support of a new branch, all of a sudden a project that looked like it was in jeopardy gets pushed along. Likewise, when our state legislators hear from their constituents in large numbers, they are much more likely to vote for, or against, a bill. If we really want to play politics, then the first thing we need to realize is that these guys won't listen to some two-bit library lobbyist when the really big-ticket lobbyists are just down the hall. Come on Ed, what do we have to "offer," free loans on videos? How is our lobbyist ever going to compete with contributions? If we really want to get our voices heard, let's do it the old-fashioned way. Let's hit them where it really hurts - with our votes! 


\title{
Library Research in North Carolina
}

\section{North Carolina Library School Faculty Research, 1991: A Compilation}

\author{
by Robert Burgin
}

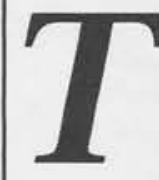

he following compilation lists the 1991 publications of the full-time faculty members in North Carolina's library schools.

Names of full-time faculty members for each of the five schools (Appalachian State University, East Carolina University, North Carolina Central University, University of North Carolina at Chapel Hill, and University of North Carolina at Greensboro) were taken from the 1991 - 1992 Directory of the Association for Library and Information Science Education. The publications were derived from several files on DIALOG (Library and Information Science Abstracts, Social Science Citation Index, and Books in Print) as well as the CD-ROM version of H.W. Wilson's Library Literature.

In all, if both co-authors of a publication are credited with a publication each, there were fifty publications in 1991 for faculty members at North Carolina's library schools. There were forty-four faculty members at the four schools whose faculty published in 1991. Consequently, the average rate of publication per faculty member for 1991 was 1.1 publications.

The most comparable study of faculty productivity (Garland 1991) reports that the mean productivity for faculty in seven disciplinary categories was about one publication per year with an average of .6 publications per year for faculty in library science. Based on these figures, the publication rate for 1991 for the faculty members of North Carolina's library schools was almost twice that of library science faculty in general and was slightly higher than the average for faculty in a wider range of disciplines.

\section{References}

Kathleen Garland, "The Nature of Publications Authored by Library and Information Science Faculty," Library and Information Science Research 13 (January-March 1991): $49-60$.

\section{Articles, Books}

Auld, Lawrence. "A Department With a View." Journal of Education for Library and Information Science 32 (FallWinter 1991): 203-206.

Bryson, Susan A., and Marilyn L. Shontz. "Young Adult Services for the Year 2000." North Carolina Libraries 49 (Summer 1991): 58-63.

Burgin, Robert. "The Effect of Indexing Exhaustivity on Retrieval Performance." Information Processing and Management 27 (6): 623-628.

Carmichael, James V. "Ahistoricity and the Library Profession: Perceptions of Biographical Researchers in LIS Concerning Research Problems, Practices, and Barriers."
Journal of Education for Library and Information Science 31 (Spring 1991): 329-356.

Chatman, Elfreda A. "Life in a Small World: Applicability of Gratification Theory to Information-Seeking Behavior." Journal of the American Society for Information Science 42 (July 1991): 438-449.

Finks, Lee W. "Librarianship Needs a New Code of Professional Ethics." American Libraries 22 (January 1991): 84-88, 90, 92. Haas, Stephanie. "Sublanguage Analysis Using the Case Hierarchy," in Proceedings of the 54th ASIS Annual Meeting, Washington, D.C., October 27-31, 1991, (Medford, N.J.: Learned Information, 1991), 196-202.

Haas, Stephanie C., and Kate Lee. "Research Journal Usage by the Forestry Faculty at the University of Florida, Gainesville." Collection Building 11 (2): 23-25.

Logan, Elisabeth L., and William M. Shaw. "A Bibliometric Analysis of Collaboration in a Medical Specialty."

Scientometrics 20 (March-April 1991): 417-426.

Losee, Robert M. "An Analytic Measure Predicting Information Retrieval System Performance." Information Processing and Management 27 (1): 1-13.

Miller, Marilyn L. "Empowering People Through Libraries: The Role of the Profession." North Carolina Libraries 49 (Winter 1991): 198-201.

Miller, Marilyn L. "School Library Media Professionals: Working for the Information Age." NASSP Bulletin 75: 43-48.

Miller, Marilyn L., and Marilyn L. Shontz. "Expenditures for Resources in School Library Media Centers FY 1989-1990." School Library Journal 37 (August 1991): 32-42.

Moran, Barbara B. "Evaluation of Faculty in Schools of Library and Information Science - An Element in Educational Excellence." Journal of Education for Library and Information Science 32 (Fall-Winter 1991): 207-215.

Mount, Ellis, and Beatrice Kovacs. Using Science and Technology Information Sources. Phoenix, AZ.: Oryx, 1991.

Pantelidis, Veronica S. Robotics in Education: An Information Guide. Metuchen, N.J.: Scarecrow, 1991.

Saye, Jerry D., and Desretta McAllister-Harper. Manheimer's Cataloging \& Classification: A Workbook. 3rd ed. New York: Dekker, 1991.

Shaw, William M. "Subject and Citation Indexing. 1. The Clustering Structure of Composite Representations in the Cystic Fibrosis Document Collection." Journal of the American Society for Information Science 42 (October 1991): 669 675.

Shaw, William M. "Subject and Citation Indexing. 2. The Optimal, Cluster-Based Retrieval Performance of Composite Representations." Journal of the American Society for Information Science 42 (October 1991): 676-684.

Shaw, William M., Judith B. Wood, Robert E. Wood, Helen R. 
Tibbo. "The Cystic Fibrosis Database: Content and Research Opportunities." Library and Information Science Research 13 (October-December 1991): 347-366.

Smith, Duncan, and Robert Burgin. "The Motivations of Professional and Paraprofessional Librarians for Participating in Continuing Education Programs." Library and Information Science Research 13 (October-December 1991): 405-429.

Speller, Benjamin F., Jr. (ed.). Educating Black Librarians. Jefferson, N.C.: McFarland \& Co., 1991.

Stevenson, Kathryn C., and Benjamin F. Speller "An Historical Chronology of the North Carolina Central University School of Library and Information Sciences." In Educating Black Librarians, edited by Benjamin F. Speller, Jr., 143-50. Jefferson, N.C.: McFarland \& Co., 1991.

Tibbo, Helen R. "Information Systems, Services, and Technology for the Humanities." Annual Review of Information Science and Technology 26: 287-346.

Tibbo, Helen R. "In Search of Total Recall: Teaching Online Searching with the Cystic Fibrosis Database." In National Online Meeting 1991: Proceedings of the 12th National Online Meeting, New York, May 7-9, 1991, 411-421. Medford, N.J.: Learned Information, 1991.

Wildemuth, Barbara M., E.K. Jacob, A. Fullington, R. Debliek, C.P. Friedman. "A Detailed Analysis of End-User Search Behaviors," in Proceedings of the 54th ASIS Annual Meeting, Washington, D.C., October 27-31, 1991, 302-303. Medford, N.J.: Learned Information, 1991.

Wright, Kieth C., and Judith F. Davie. Serving the Disabled: A How-to-Do-It Manual for Librarians. New York: NealSchuman, 1991.

\section{Book Reviews, Letters, Others}

Auld, Lawrence. "Academic Libraries: Research Perspectives, Edited by Mary Jo Lynch and Arthur Young." Library Resources and Technical Services 35 (April 1991): 229-230. [Book Review]

Broadus, Robert N. "The Decision-Making Process for Library Collections: Case-Studies in 4 Types of Libraries, by Beatrice Kovacs." Library Quarterly 61 (April 1991): 233-234. [Book Review]

Burgin, Robert, and Patsy Hansel. "Library Management - A Dialogue." Wilson Library Bulletin 66 (November 1991): 52-55. [Column]

Burgin, Robert, and Patsy Hansel. "Library Management - A Dialogue." Wilson Library Bulletin 66 (September 1991): 66-68. [Column]

Burgin, Robert, and Patsy Hansel. "Communication." Wilson Library Bulletin 65 (May 1991): 84-87. [Column]

Burgin, Robert, and Patsy Hansel. "Participative Management." Wilson Library Bulletin 65 (March 1991): 77-79. [Column]

Burgin, Robert, and Patsy Hansel. "Delegation - A Real Art." Wilson Library Bulletin 65 (January 1991): 64-67. [Column]

Carmichael, James V. "The Future of the Past." North Carolina Libraries 49 (Summer 1991): 99-101. [Column]

Carmichael, James V. "Keeping Culture in Sight." Library Journal 116 (August 1991): 8. [Letter]

Carmichael, James V. "Reading and Libraries - A Brief Report of Library History Seminar VIII." Libraries \& Culture 26 (Summer 1991): 540-546. [Note]

Collins, Donald E. "Reference Readiness: A Manual for Librarians, Researchers, and Students, by Agnes Ann
Hede." Journal of Academic Librarianship 17 (March 1991): 33-34. [Book Review]

Holley, Edward G. "Not an Uncaring Monopoly." Library Journal 116 (June 15, 1991): 12. [Letter]

Holley, Edward G. "Literacy and Popular Culture: England, 1750-1914, by David Vincent." Library Quarterly 61 (April 1991): 224-225. [Book Review]

Miller, Marilyn L. "Action Priorities for the '90s." School Library Journal 37 (May 1991): 53. [Column]

Miller, Marilyn L. "Library Education and Employer Expectations, Edited by E. Dale Cluff." Information Technology and Libraries 10: 77-78. [Book Review]

Miller, Marilyn L., Charles Bunge, Marvin Scilken, Herb. S. White. "ALA Candidates - Why Choose." Library Journal 116 (April 1, 1991): 74-82. [Interview]

Shearer, Kenneth D. "Language Distribution in Databases: An Analysis and Evaluation, by Gretchen Whitney." Journal of the American Society for Information Science 42 (August 1991): 537-538. [Book Review]

Steinfirst, Susan Z. "Jessie Willcox Smith: American Illustrator, by Edward D. Nudelman." Library Quarterly 61 (April 1991): 238-240. [Book Review]

Wildemuth, Barbara M. "SIG MGT - Information Behavior of Managers," in Proceedings of the 54th ASIS Anmual Meeting, Washington, D.C., October 27-31, 1991, 360. Medford, N.J.: Learned Information, 1991. [Note]

Wildemuth, Barbara M. "Developments in Microcomputing Discovering New Opportunities for Libraries in the 1990s: 12th International Essen Symposium, 23 October - 26 October 1989, Edited by A.H. Helal and J.W. Weiss." Information Processing and Management 27 (5): 594-595. [Book Review]

\section{Tired of making "permanent loans?"}

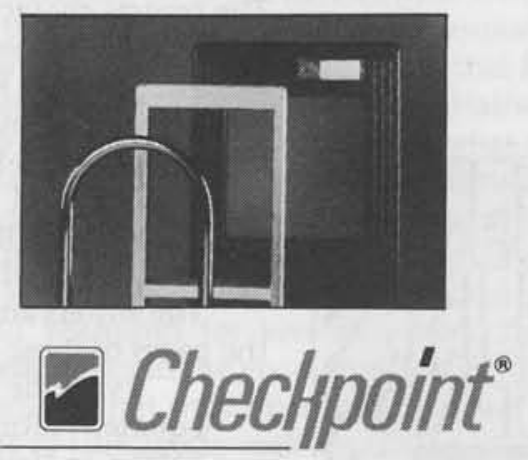

Tomorrow's Technology for Today's Libraries ${ }^{\mathrm{TM}}$

550 Grove Road - P.O. Box 188 - Thorofare, New Jersey 08086 (800) 257-5540 - TELEX: 84-5396 - FAX: (609) 848-0937

Wes Brewer, Sales Representative

2921 Welcome Drive

Durham, North Carolina 27705

(919) 493-2161 


\section{NORTH CAROLINA}

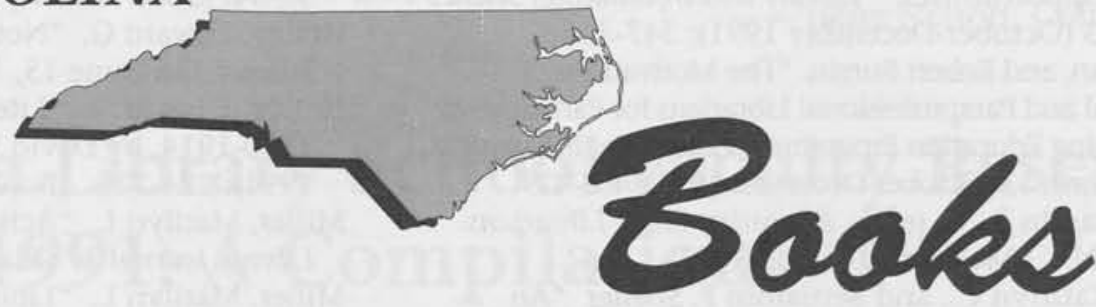

Robert G. Anthony, Jr., Compiler

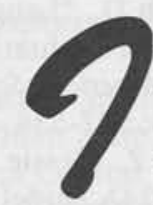

n a short documentary entitled "Four Women Artists," produced by the Center for Southern Folklore, Eudora Welty describes how she feels when an author uses a descriptive color that does not fit. She finds it difficult to continue reading the work, regardless of how well it might be written. The author may have been careless or simply unobservant, but the effect on some readers is the sense that something has been spoiled. Randall Kenan, the young black author of this collection of fine short stories, Let the Dead Bury Their Dead, seems awfully close to making something like that mistake in his first short story, "Clarence and the Dead." It reads a little too much like Southern Gothic by the numbers - he's got the dialect perfected, he's got the rhythm of the lifestyle running well, and he's clearly given us a sense of place. It's well done, but nowhere near as rich, sensual, or startling as the remaining stories.

Kenan, born in Chinquapin, North Carolina, makes much use of his heritage and memories of life in what those of us from that part of the world call "down East." In his writing, one feels, sees, or just recalls Randall Kenan. the dark richness of Eastern North Carolina's still undersettled flatlands.

\section{Let the Dead Bury Their Dead.}

New York: Harcourt Brace Jovanovich, 1992. 334 pp. \$19.95. ISBN 0-15-149886-5.
Tim's Creek evokes very strong images of small towns and back roads "down East." His stories are filled with familiar sounding names and places. They are rich with expressions that have long been cast aside by some of us.

There is the richly sensual humor of "What Are Days," the story of a woman in late middle age drawn into a brief but sexually liberating affair with a nineteen-year-old boy, or was he just some phantasm? In "Cornsilk," a love affair between a brother and his sister is told in language dripping with sensuality and heavy sexual play. Even so, it is also a story about the battle between a father and son, and of a son's uncertainty about loving his father. The central character in "Cornsilk" is an intellectual and sexual wanderer-a black urban yuppie with his own hysterical angst.

The people in Kenan's stories are of simple hues-they are black or white, male or female. But, in what seems like an incredible piece of literary finesse, he writes of each with an objectivity that is thrilling. You know the color of a character's skin by quirks of language or by some kind of instinct-Kenan rarely has to tell you. His women, Jamonica in "Cornsilk," Lena Rose, Mabel Pearsall, and Bela in "Tell Me, Tell Me," are strongly written observations of what women might think or feel.

The writers and writings, the stories and myths that have influenced Kenan flow from the pages of these stories:

I've done my reading. All my homework. Should I tell you what I've found? Shall I quote Whitman or Auden or Pound? Shall I give you a Canto or a Quartet? Hughes or Baraka or Hayden? Lincoln or Dubois? Eliot's "No! I am not Prince Hamlet, nor was meant to be"?

We get glimpses of the pantheon of American literature in all its complex and boundless guises-African American, Southern Gothic, Modern Poetry. There are pieces of Faulkner and Alice Walker and traces of James Weldon Johnson "Simple" stories. The language is as graceful as Walker Percy and voluptuous as Zora Neal Hurston. Kenan turns these influences, plus dozens of others, into his own special creation. He has created in Tim's Creek a wondrous world peopled with characters that may remind some of us of places and things almost forgotten. Let the Dead Bury Their Dead is a truly original work. Kenan offers us extraordinary promise of what a fine writer can and should feel confident creating - the mosaic of cultures and colors America is. This is a very, very fine collection of stories. One pleads for more. 
oriden helped Gordon Weekley sleep. Dexamyl gave him energy. Together, these prescription drugs controlled this Baptist minister's life for eighteen years.

$H$. Gordon Weekley found his calling early, and his successes came easily. In 1958, as pastor of the newly established and quickly growing Providence Baptist Church in Charlotte, North Carolina, Weekley found himself overworked, overtired. To help him sleep, a doctor prescribed Doriden, "a new wonder-drug ... it's safe and non-addictive." With the rest and euphoria the drug produced, Weekley became more and more involved in his church work, even taking part in international mission trips with Billy Graham. It was on a trip to Africa in 1960 that he discovered Dexamyl, a diet pill that provides a rush of energy. Doctors made

Don Jeffries. prescriptions available without question, and for years Weekley took the two drugs day and night. When his family and church leaders finally questioned his behavior, he denied having any problem and began acquiring the drugs on the sly. Over the years he lost his job, family, and home; but he continued to deny his chemical dependence.

Treatment was ineffective. The bulk of this biography is a chronicle of A Baptist Preacher's Personal Journey through Addiction.

Little Rock, Ark.: August House, 1992. 238 pp.

$\$ 19.95$. ISBN 0-87483-190-3. rehabilitation programs, therapy, mountain retreats, even mental hospitals, but each program left Weekley confident that he could control his addiction. At last, surrendering his problems to God, he overcame the need for drugs, became director of the Rebound Christian Rehabilitation Center in Charlotte, and resumed his ministry.

As a biography, Balm in Gilead lacks the energy and style needed to sustain interest. Important characters such as Weekley's wife, Norma Sue, are under-developed. Jeffries, an advertising executive and a member of the board of directors of Weekley's rehabilitation center, has chosen a journalistic style that is unemotional and excessively detailed, and which suppresses an understanding of Weekley's motivation. The scene where Weekley prays for help, and receives it, is underplayed and leaves the reader bewildered and cynical.

The volume is somewhat more successful as a case study in denial and will be of value to libraries with strong psychology, social work, or drug abuse collections.

- Lisa K. Dalton, Rockingham County Public Library

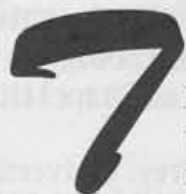

he tragedy of incest has been visited frequently in recent fiction. It is a powerful theme, yet perilously close to being overdone. In Angela Davis-Gardner's second novel, this difficult topic is approached honestly without being brutal.

The main character, Beryl, experiences all the expected emotions of an adolescent girl growing up in the South in the 1950s. The author draws upon the ordinary to weave a landscape of familiar, comforting images: a pony, a "poodle" skirt, a treehouse, a young girl's diary, a sneaking off to the movies with town boys despite parental disapproval. But beyond this realm of the normal are dark shadows.

One assumes from the dust jacket blurb that Forms of Shelter is going

Angela Davis-Gardner.

Forms of Shelter.

New York: Ticknor \& Fields, 1991. 276 pp.

\$19.95. ISBN 0-395-59312-3. to be about secrets - secrets such as incest. Halfway through the novel, however, this reviewer was no longer sure what to expect. The sudden uncertainty compels the reader onward, and this reviewer finished the novel with unusual speed. There is that constant, awful feeling of hope that everything will turn out fine.

Forms of Shelter is not a happy story, yet it is a warm one of a family full of wistful yearnings for love but desperately confused, ill, and

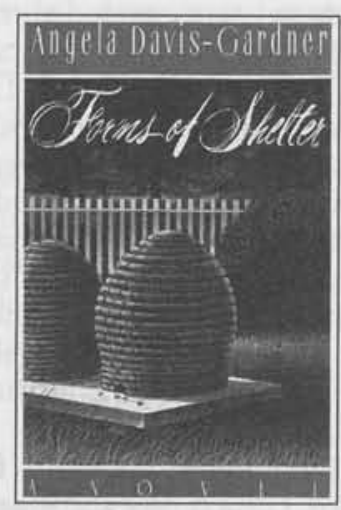

Norith Carolina Libraries destined to pain. The book's strength lies in the vivid portrayal of Beryl-and in the clarity with which she remembers incidents that were often never meant to be but nevertheless happened. Her father disappears to Chicago to seek his fame as a jazz musician, never to return. Her mother teeters on the edge of serious depression. Rigidly religious grandparents provide some stability but no warmth. Beryl's brother, Stevie, retreats into his own private world. When an academic stepfather enters the picture, his off-beat house and lifestyle bring ridicule from the kids at school and keep tensions high on the family front.

Davis-Gardner's style makes all this work. The characters are believable; they come alive for the reader. Beryl's confession flows naturally. One finishes the book with a clear sense of the struggles the characters have faced. The resolution of the conflict and surmounting of obstacles seem real.

This book is suitable for adult fiction collections in academic and public libraries and is a must for collections of North Carolina writers. Davis-Gardner, a native North Carolinian, is an assistant professor of creative writing at North Carolina State University, Raleigh.

- Eleanor I. Cook, Appalachian State University 


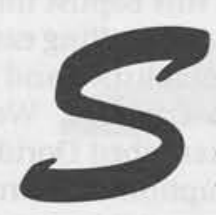

"[T] he fires came gradually. Deceptively."

$\mathrm{o}$, too, the inner rages smoldered. Festival citizens were frenzied. Their attention focused on the politics and preparation of the annual Azalea Festival-more concerned with "proper" community image and political implications than with the menacing yellow smoke-veiled sky and the increasing subliminal uneasiness.

The setting is 1988-1989, in the coastal area of fictional Festival and Festival Beach, North Carolina. Events unfold for the reader through the perspectives of Jordan Edge, once "stalked by humiliation" as the prologue's 1967-68 high school freshman newcomer, now a school administrator and volunteer firefighter; Alona Wand, shopkeeper and jewelry-maker whose recurring dream of flowing hair bright as light now awakes her with nightmarish shivers; and Cassie,

Ellyn Bache. fourteen, whose rebellion against her county commissioner stepfather Festival in Fire Season.

Little Rock, Ark.: August House, 1992. 239 pp. \$19.95. ISBN 0-87483-189-X. and his thinly veiled bigotry intertwines the lives of these key figures as they duel with their innermost fears.

Bache is skillful in developing the personae of these three major characters and those with whom their lives interact. This well-researched, quick-paced novel with its interest in relationships and societal attitudes unfolds through crisp narrative and vivid description. It elicits the reader's sensory imagination, drawing one into the inten-

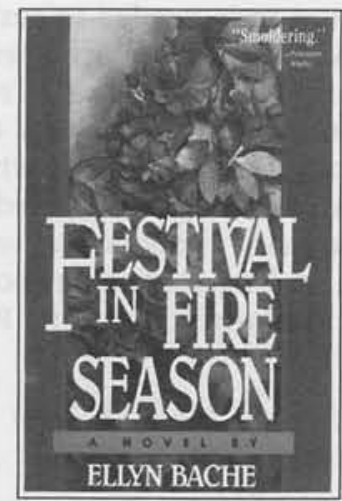
sity of the moment. Bache has carefully researched the nature of fires and the tactics of firefighting, acknowledging the editorial assistance of several North Carolina fire fighters. While this reviewer roiled at the attitudes and language of the prologue, its necessity and relevance to understanding the inner struggle and later perspective of each major character are gradually revealed. Fear and courage, love and tragedy collide in this readable book that evokes the humor and compassion of a realistic world-where confusion precedes truer understanding. This book is appropriate for public and academic library fiction collections, and is not inappropriate for senior high collections given the readability and treatment of a universal topic.

Winner of several literary awards and a North Carolina Writers' Network instructor, Ellyn Bache has received critical acclaim for her first novel, Safe Passage (1988), and for her autobiographical sketch, Culture Clash (1982), the latter now in its second edition (1989). Bache's short stories have appeared in anthologies, as well as in popular and literary magazines. A University of North Carolina at Chapel Hill graduate, she lives with her family in Wilmington, North Carolina.

- Libby Grey, University of North Carolina at Chapel Hill

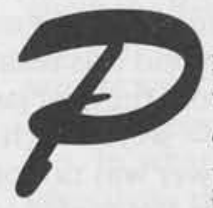

rice's twenty-third book, Blue Calhoun, is summarized by its beginning sentence, "this starts with the happiest I ever was though it brought down suffering on everybody near me." Sixty-five-year-old Blue Calhoun's story is told in first person as a lengthy letter. He explains to his granddaughter the relationship between her father's recent suicide and Blue's own affair with a young girl thirty years earlier.

The book begins in 1956 when a younger Bluford Calhoun was a recovering alcoholic who had been in control of his actions for only a long year and a half. After causing almost two decades of misery to his religious family, Blue was finally repaying their faith in him by working hard as a salesman in a music store. His steady existence ended abruptly when he fell in love with sixteen-year-old Luna Absher while selling her an Autoharp. His passion stunned him. When he saw Luna, he later Reynolds Price. recounts, "My whole body felt like a child a-borning, pushed helpless down a dim long tunnel towards strong new light." Driven by weakness and circumstances, Blue eventually leaves his wife and child for an interlude of sexual ecstasy and self-fulfillment with Luna.

Despite the pain Luna and Blue inflict on the latter's good-hearted family, Price manages to maintain the reader's compassion toward the lovers with his depiction of their honesty. Neither has illusions about him - or herself or their future together. Each finds healing in their brief, innocent, loving relationship.

Price's critics have suggested that women are his finest literary creations, from Rosacoke Mustian in A Long and Happy Life to Kate in Kate Vaiden. Luna is no exception in her role of a good woman/child despite her unselective promiscuity. From a childhood filled with 
sexual abuse by her brother and father, she relates to men through the pleasure her body yields them. Her character is the chief vehicle for threading the crippling aspects of incest through the plot. As with all the women in Blue's story, Luna's strength is greater than his, as is poignantly illustrated when she arranges his return to his family and to a reformed life. When Blue is reunited with Luna decades later, he trusts her kindness and wisdom to help his granddaughter recover from the traumatic experience of incest with her father.

For Price's loyal following, Blue Calhoun will impart familiar pleasures. In this book, he repeats the theme of a tragic event in a family affecting characters' lives for several generations, a theme he developed fully in The Surface of the Earth and its sequel, The Source of Light. North Carolina small-town life, specifically Raleigh before suburban sprawl, is drawn like a peaceful road map of times past. For all readers, Price's use of language, especially in his characters' natural, poetic dialogue, is a joy to be discovered and rediscovered with each novel.

- Christine L. Thomson, Saint Mary's College

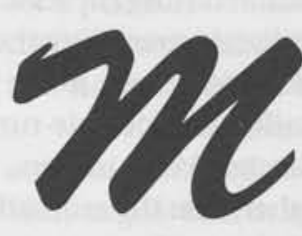

ost North Carolinians are well aware of the enormous popularity of the National Collegiate Athletic Association (NCAA) Division I men's basketball tournament. In recent years teams from this state have had considerable success in that three-week-long extravaganza, winning four titles since 1982 . That popularity and that success are celebrated in these two books.

One to Remember commemorates the tenth anniversary of the University of North Carolina at Chapel Hill's 1982 title, a team which featured future professional stars James Worthy, Michael Jordan, and

David Daly.

One to Remember: The 1982 North Carolina Tar Heels NCAA Championship Team, Then and Now. Asheboro, N.C.: Down Home Press, 1991. 120 pp. \$34.95. ISBN 1-878086-10-3.

Mike Cragg and Mike Sobb.

$$
\text { Crowning Glory: }
$$

The Story of Duke's 1991 NCAA Championship Season.

Durham: Sports Information Office, Duke University, Cameron Indoor Stadium, Durham, N.C. $27706,1991.120$ pp. $\$ 29.95$. Sam Perkins. Crowning Glory was produced within months of Duke University's successful 1991 championship run, which was led by Christian Laettner, Grant Hill, and Bobby Hurley. There are some interesting parallels between the rival teams. Both won the national title after finishing second the previous year. The two titles were the first national championships respectively for coaches Dean Smith of North Carolina (Frank McGuire coached UNC's 1957 NCAA champions) and Mike Krzyzewski of Duke after a number of near-misses that caused some observers to question their ability to win "the big one."

Crowning Glory is a more substantial work in several areas. Cragg and Sobb, who work for the Duke Sports Information Office, have called on the services of a pair of Duke alumni for special chapters. Sportswriter Bill Brill contributes a segment entitled "Historical Perspective," which unfortunately gives too-brief coverage to the preKrzyzewski years. John Feinstein, arguably the country's best-known writer on college basketball, furnishes a chapter on Duke's Final Four victories over the University of Nevada-Las Vegas and the University of Kansas. Cragg and Sobb detail the other four NCAA games and summarize the 1990-1991 season in other chapters. A substantial portion of the book is devoted to largely matter-of-fact profiles of the Duke player. Crowning Glory's appeal is considerably enhanced by a large number of color photographs.

\section{TMUMFORD}

- Over 90,000 Books in Stock

- Over 10,000 Titles

- 13 Years of Service

- "Hands On" Selection

- Pre-School Through Adult

\section{RELIABLE WHOLESALER SINCE 1977}

- Discounts up to $70 \%$ Off

- Now Two Adjacent Warehouses

- Sturdy Library Bindings

- $100 \%$ Fill

- Cataloging/Processing Available

MUMFORD LIBRARY BOOKS, SOUTHEAST, INC.

7847 Bayberry Road • Jacksonville, Florida 32256

(904) $737-2649$

North Carolina Representative - Phil May 
Neither One to Remember nor Crowning Glory is intended to provide profound insights, and neither does. Neither has a bibliography or an index, although Crowning Glory does have a useful statistical summary of the 1990-1991 Duke season. Both are oversized coffee-table books designed largely for fans of the respective teams. Of course, that category encompasses a large percentage of North Carolina's population.

- Jim Sumner, North Carolina Division of Archives and History

\section{Other Publications of Interest}

Incorporated in 1740 as Newton, Wilmington has for most of its history been North Carolina's principal port. Its strategic and secure harbor on the Cape Fear River, thirty miles inland from the Atlantic Ocean, attracted British military occupation during the American Revolution. In the two decades immediately preceding the Civil War, it emerged as an important railroad terminus, as the port end of the Wilmington and Weldon Railroad. Blockade-running ships fed supplies so successfully through Wilmington, which was well protected by nearby Fort Fisher, that the railroad earned the nickname "Lifeline of the Confederacy."

In Wilmington, Port of North Carolina, Alan D. Watson details these and other chapters in the city's history. Post-Civil War highlights have included service as headquarters city for the Atlantic Coast Line railroad, the construction of 243 vessels, including 126 "Liberty Ships" during World War II, and the

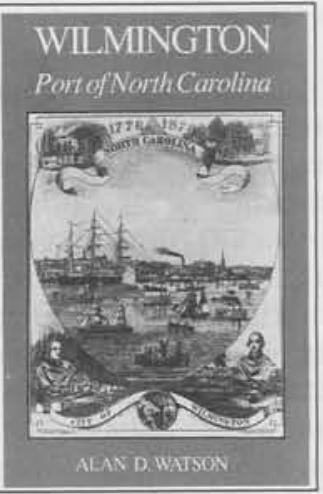
creation of the State Ports Authority and state aid for port facilities development after that war. Extensive footnotes and an impressive bibliography will facilitate further research by readers interested in this city whose future promises to remain, as its past has been, closely linked to the waters nearby. (1992; University of South Carolina Press, 1716 College Street, Columbia, S.C. 29208; 213 pp.; \$29.95; ISBN 0-87249-778-X; cloth.)

In 1991, during three day-long sessions, the Public Library of Charlotte and Mecklenburg County invited citizens to bring to the library photographs depicting the history of post-Civil War black life in the county. The goal was to secure copies to add to the library's Carolina Room' collections of approximately five thousand photographic prints and seven million photographic negatives, large collections with little showing the life of local African Americans. The response was overwhelming, with 1,500 photographs offered for copying by volunteer professional photographers. Now, approximately 170 of those images have been selected and reproduced in An African American Album: The Black Experience in Charlotte and Mecklenburg County, Elizabeth S. Randolph, editor, and Pat Ryckman, project coordinator.

Divided into six categories-Home \& Family, Education, Work, War, Religion, Community - the photographs show proud and vibrant people engaged in events, both

\section{The Children's Book Council Inc.}

Fred Marcellino has created a full-color 17 " $\mathrm{x} 22$ " poster encouraging readers to READ ... THINK ... DREAM ... during the 1992 Book Week celebration, November 16-22, 1992.

This poster features a sequence of pictures of a cat and his mouse friend quietly reading a book, then leisurely thinking about what they have read, and finally sleeping comfortably as they dream pleasant book dreams. The poster is included in the Council's official Book Week kit which sells for $\$ 27.50$. It may also be purchased separately (prepaid only) for $\$ 7.00$.

For a full-color brochure that pictures the poster and all other Book Week materials, send a business (\#10), stamped ( $1 \mathrm{oz}$. first class), self-addressed envelope to: "Materials Brochure," Children's Book Council, 568 Broadway, Suite 404, New York, NY 10012.

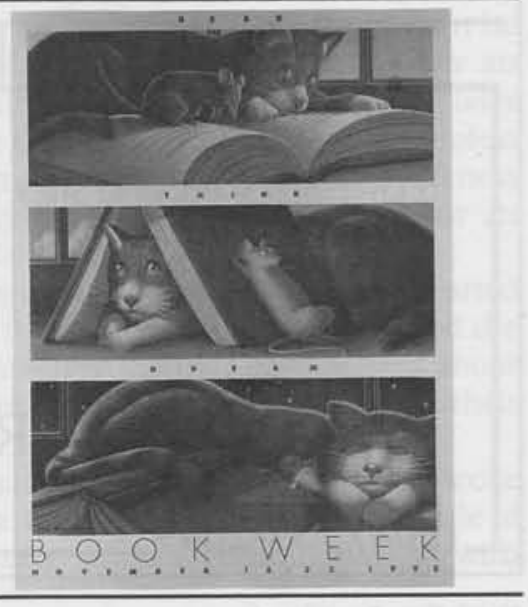


ordinary and extraordinary, that marked the years between the 1870 s and 1950 in Mecklenburg County. The result is an attractive coffee-table book, but one that offers the viewer/reader a fuller understanding of, and appreciation for, the history of North Carolina's Queen City and its surrounding area. (1992; Public Library of Charlotte and Mecklenburg County, Attn. Carolina Room, 310 N. Tryon Street, Charlotte, N.C. $28202-$ 2176; 137 pp.; $\$ 30.00$, plus $\$ 5.90$ tax and shipping; cloth.)

A prominent planter and politician from Brunswick County, North Carolina, at the beginning of the Revolutionary War, Robert Howe quickly emerged as a major military leader. As commanding general of the Southern Department and highest-ranking officer from the states south of Virginia, he was positioned for a pivotal role in the defense of the emerging nation. Yet Howe's "loss" of Georgia by failing to defeat the British invasion there in 1778, his reputation as a "womanizer," and his inability to secure important cooperation from state and local political officials, helped lead to his removal from the Southern command and transfer to the Northern states. They also caused many to view him as an ineffectual military commander and helped destine him to become "Washington's forgotten general" among historians.

In A Quest For Glory: Major General Robert Howe and the American Revolution, authors Charles E. Bennett and Donald R. Lennon seek to rescue Howe from his obscurity. They argue that in many ways he was the victim of the conflicts and jealous rivalries that divided military and civilian authorities, and they offer the first comprehensive biographical treatment of this interesting Tar Heel. (1991; University of North Carolina Press, P.O. Box 2288, Chapel Hill, N.C. 27515-2288; 205 pp.; \$24.95; ISBN 9-8078-1982-4; cloth.)

Countless Americans find their sports heroes not on football fields or basketball courts or hockey rinks, but at stock car motor speedways located around the nation, especially in the South. In The Intimidator: The Dale Earnhardt Story, An Unauthorized Biography, Frank Vehorn relates the rise of one of today's most cheered - and most booed - stock car drivers. Dale Earnhardt, a high school dropout from Kannapolis, North Carolina, learned the sport early and well, following his racer father in the 1950 s and 1960 s to small racetracks around the South.

In the 1980 s and early 1990s, the younger Earnhardt has emerged as a talented and fierce competitor known perhaps as widely for his involvements in controversial car bumpings and fender rubbings as for his victories in races. Some readers may be put off by the book's informal, journalistic style, its lack of full citations for quotations from $\mathrm{E}$ arnhardt and other drivers, the absence of statistical charts and tables to help compare drivers, and several amateurish production features, such as the meaningless contents page. But others may enjoy this look at an important player in a major American sport. (1991; Down Home Press, P.O. Box 4126,

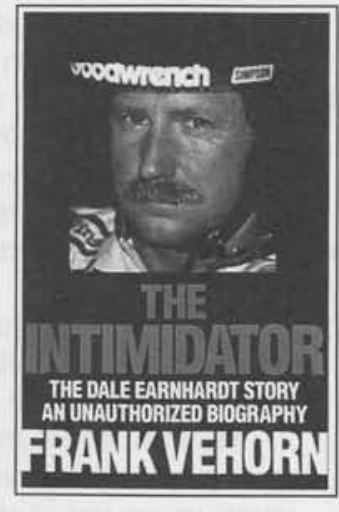
Asheboro, N.C. 27204; 288 pp.; \$13.95; paperback.)

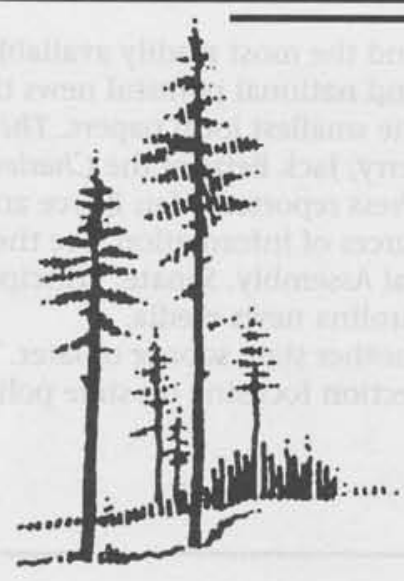

Thorndike Press Large Print Books 

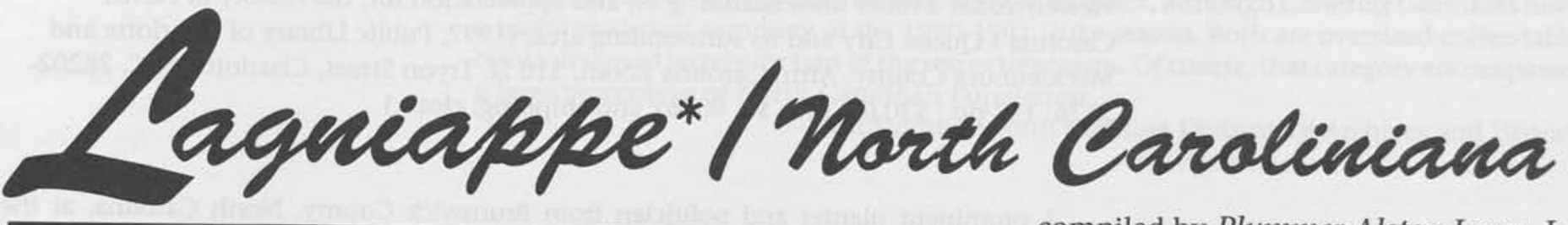

compiled by Plummer Alston Jones, Jr.

Editor's Note: "Lagniappe/North Caroliniana," the newest feature column of North Carolina Libraries, is envisioned as a complement to "North Carolina Books." As such, "Lagniappe/North Caroliniana" will feature reviews of materials in various non-book formats presenting fictional or nonfictional accounts on North Carolina or the Southern regions which include North Carolina (e.g., the Appalachians, the Southeast, the Old South, the New South, etc.). Publishers and creators of non-book materials which meet these criteria should forward materials for possible review. Reviews of up to 250 words are welcomed and will be considered for publication. Send materials and reviews to Plummer Alston Jones, Jr., c/o Iris Holt McEwen Library/LaRose Resources Center, Elon College, P.O. Box 187, Elon College, NC 27244-0187.

\section{Librarians in the Political Process: Selected Resources}

by Pat Langelier

Question: How can I keep up with what the General Assembly is doing about x ( $\mathrm{x}=$ any pending legislation)? How can I influence the outcome of this pending legislation?

Answers: Who has a stake in $\mathrm{x}$ ? What state agencies and legislative committees influence what happens with $\mathrm{x}$ ? Who will be affected by legislative and/or regulatory changes in $\mathrm{x}$ ? Local government? Business? Industry? Schools? What is happening in other states with $\mathrm{x}$ ? What is Congress doing about $\mathrm{x}$ ?

Whether you're interested in following political news to respond to reference questions or to get involved in the political process itself, you'll find a number of resources listed here to answer your questions and to lead you to other sources of information. Librarians who are experienced with the political process in North Carolina would surely add to or subtract from this list.

To confirm my own practices, and to find out how others keep up with politics, legislation, and government at the state level, I conducted an informal survey. Included in my sample were a political scientist, public, special, and academic librarians, and attorneys. The resources cited most often are included in this guide. The name of the publisher of each resource discussed here appears in a parenthesis after the initial citation. More complete information on each of these publishers appears at the end of this review.

Móre sources are listed than most people are likely to use on a regular basis. Try out a new source or vary your daily news diet from time to time to broaden your familiarity with its strengths and weaknesses and to hear other viewpoints.

The single most important source of political information and the most readily available is the local newspaper. Some newspapers publish more state and national political news than others, although wire service stories can be found in even the smallest local papers. The News and Observer, the Herald Sun's columnist Danny Lineberry, Jack Betts of the Charlotte Observer, the Greensboro News \& Record, and the Associated Press reporters Alan Boyce and Dennis Patterson were specifically mentioned as reliable sources of information. See the latest biennial Senate Rules-Directory (North Carolina. General Assembly. Senate. Principal Clerk) for a directory of state capital reporters and North Carolina news media.

The problems experienced by one state usually affect another state sooner or later. The Wall Street Journal's (Dow Jones \& Co.) "Politics \& Policy" section focusing on state politics appears on the last page of the first section. 
The Almanac of American Politics (National Journal) is required reading for an understanding of local, state, and national politics. This biennial publication of the National Journal provides historical background, a survey of the political landscape, and demographic information about every state and Congressional district, directory information, and biographical profiles of the president, governors, big-city mayors, senators, and representatives. Legislators' votes on key issues are listed, along with effectiveness rankings and ratings by ten major lobbying organizations.

The Washington Information Directory (Congressional Quarterly, Inc.) is my all-time favorite resource. It contains listings of foundations and private, nonprofit organizations located in the D. C. area, federal government agencies, congressional committees, state officials and mayors of major cities. Its subject arrangement simplifies gathering information about all the major forces concerned with a piece of legislation. A section on libraries and information science lists relevant federal agencies and commissions, congressional committees, federal departmental and agency libraries, and nongovernmental organizations such as the American Library Association (ALA), the American Society for Information Science (ASIS), the Association of Research Libraries (ARL), the Council on Library Resources (CLR), the Information Industry Association (IIA), and the Special Libraries Association (SLA).

Request a copy of the (Year) General Assembly of North Carolina Telephone Directory. Compiled by the Legislative Services Office, it lists names, addresses, and phone numbers of state legislators, staff members, and committee chair assignments. The North Carolina Legislative Directory, published biennially by Southern Bell, contains photos, and name and address information for state legislators.

Information about lobbyists is available from the Secretary of State's office. Legislative Agents for the (Year) General Assembly Directory lists registered lobbyists and the businesses, industries, and organizations they represent. New editions of the directory are published as needed throughout the session.

To lobby effectively, learn as much as possible about our state legislators. Article II: A Guide to the 1991-1992 N. C. Legislature (North Carolina Center for Public Policy Research), published biennially in odd-numbered years, contains legislator profiles that include a photo, date of birth, home, business, and legislative addresses and phone numbers, political affiliation, district represented, committee assignments, legislative service, occupation, educational background, a selective list of bills introduced, key votes, and effectiveness rankings (as judged by colleagues, lobbyists, and capital news correspondents). Article II also contains a list of representatives by district, demographic information (sex, race, and political affiliation statistics), and a list of House, Senate, and joint legislative committees. The biennial North Carolina Manual (N. C. Department of the Secretary of State) duplicates some of this information and provides additional information, such as service on boards, military service, and family information, but is published too late to be relied on for current information. The Manual is useful primarily as an official historical record.

Other publications of the North Carolina Center for Public Policy Research that should be on your reading list include their quarterly magazine North Carolina Insight. It contains timely, well-researched articles on issues of public policy. NC Focus: An Anthology on State Government, Politics, and Policy (1989) is a compilation of articles from North Carolina Insight that offers a basic education on state government and politics. For example, one chapter describes the complex process of determining how legislators voted on an issue; another chapter explains how to evaluate the results of a political poll.

Understanding how the North Carolina legislature works is essential. The General Assembly of North Carolina: A Handbook for Legislators (Institute of Government), the sixth edition published in 1990 being the latest, describes legislative organization and process in North Carolina. It contains a chapter that illustrates the steps in the legislative process, and another that explains the budget process.

In addition to the news it offers, each issue of Governing the States and Localities (Congressional Quarterly, Inc.) will help you understand more about the operations of state and local government. For example, the June 1991 issue contained a special "Governing Guide" entitled "Managing Public Money." It explains how the budget process works in state and local governments, describes the accounting and reporting functions and the responsibilities of finance officers, provides the questions to ask to measure your government's fiscal health, and lists twenty- nine organizations, corporations, and educational institutions to contact for further information. At the national level, Congressional Quarterly Weekly Report is another excellent source of news about politics and government from Congressional Quarterly, Inc. It provides detailed coverage of presidential activities and congressional legislation. 
Tracking the General Assembly

Each day the North Carolina General Assembly is in session, the Institute of Government's Daily Bulletin reports on the General Assembly's activities for members of the legislature and others interested in the course of legislation. The Daily Bulletin contains digests of each bill, amendments, and committee substitutes introduced, and a comprehensive calendar of daily actions. From time to time the Daily Bulletin lists committee assignments, summarizes messages by the governor, and reports other actions relating to the structure or organization of the General Assembly. The legislative reporting service of the Institute also publishes periodic status reports, an index of legislation, and a summary of each session's accomplishments, entitled North Carolina Legislation. Another handy Institute of Government publication is the Chart of the Administrative Organization of North Carolina State Government (1992) which lists all agencies created by the state constitution, statute, or executive order. It shows in table form the location of each department within the executive, legislative, or judicial branch of government. Other Institute publications, including the quarterly Popular Government, carry articles on North Carolina state and local government.

Real-time reference requires use of one or more of the following sources. Electronic bulletin board systems such as the statewide North Carolina Information Network (NCIN) and RESPOND, sponsored by the North Carolina Association of County Commissioners, offer quick, free access to news and a means to communicate with one another. On NCIN, you will find NCNEWS and the NCGOV bulletin boards prepared by the North Carolina Association of County Commissioners. NCNEWS is a summary of each bill affecting counties and its status; NCGOV provides news of interest to local government officials.

The databases provided by the North Carolina Association of County Commissioners, available through NCIN, are also accessible directly from the RESPOND bulletin board. In addition, RESPOND offers other features, such as the Annual Financial Information Reports (AFIR). Filed annually in the State Treasurer's Office, AFIR reports summarize annual budgets and revenues of each municipality and county. So far, the AFIR reports file contains data for two fiscal years. LOGIN (Local Government Information Network) is a national fee-based information system for local governments. It offers many interactive services and electronic versions of several periodicals including City \& State and Governing.

Computer conferencing and e-mail (electronic mail) are becoming more popular as means of communicating and are being used by librarians to alert colleagues about pending legislation. One such computer conference is GOVDOC-L@psuvm.bitnet. It allows librarians to spread news quickly about changes in federal legislation, and pending votes. E-mail is another means used by librarians to exchange news about legislative activity. As more North Carolina librarians connect to e-mail, it will become an important means of sharing news of pending state legislation.

\section{Radio}

Tune in to local radio stations that are committed to reporting state and local government news. At the national level, National Public Radio's All Things Considered has a huge listening audience, many of whom are frequent library users. NPR encourages local affiliates to contribute stories. Contact your local station to report newsworthy events and issues.

C-Span (Cable Satellite Public Affairs Network) has been called the "television newspaper of record," because it provides "a daily, unedited chronicle of the nation's public life." 1 A not-for-profit cooperative of the cable industry, C-Span and C-Span 2 are known primarily for gavel-to-gavel coverage of the House of Representatives and Senate. The two C-Span channels also broadcast political party conventions, presidential campaign events, and committee proceedings. C-Span also offers daily call-in programs featuring guests from the federal government, press conferences, debates, and think-tank panels.

C-Span has been emulated by several states, including North Carolina. Open Public Events Network, operated by the North Carolina Agency for Public Telecommunications (North Carolina Department of Administration), airs every Tuesday and Thursday from 8 p.m. to 10 p.m. on local cable television stations. Programs include OPEN/Net and Inside North Carolina, live call-in programs connecting viewers with top state officials to discuss state government services and issues, and State to State, a national live call-in program. CNN (Cable News Network) offers twenty-four-hour news programming to cable viewers. 
When the General Assembly is in session, Legislative Report is television worth watching, especially as a complement to local newspapers, to monitor current legislation. The program, produced by the North Carolina Center for Public Television, provides daily coverage of legislative activities. Stateline airs weekly when the Legislature is not in session. A third program on North Carolina Public Television with news about government and politics is North Carolina People, a show that focuses on North Carolina's leading citizens. Washington Week in Review (Corporation for Public Broadcasting) covers the activities of the federal government and Congress.

DataTimes, DIALOG, Dow Jones News/Retrieval, Legi-Slate (Washington Post), LEXIS/ NEXIS (MeadData Central), NewsNet, VU/TEXT, Washington Alert Service (Congressional Quarterly, Inc.), and Westlaw (West Publishing Co.) are excellent sources of current news. For example, the Washington Alert Service provides full text of the Congressional Quarterly Weekly Report. It also provides access to committee reports and bill digests, the full text of bills, the Congressional Record, and the Federal Register, daily news summaries, the Billtrack service, the Reuter Transcript Service, and committee and floor schedules. ${ }^{2}$

Washington Alert Service and similar databases are very expensive and hence inaccessible to many librarians and end users. CompuServe and GEnie are consumeroriented database services offering access to news at a lower cost. ${ }^{3}$

If we are to have strong effective libraries in North Carolina, we must have librarians who are able individually and collectively to influence public policy and community action. The resources listed here will help us further develop this individual and collective influence.

CompuServe, Inc., 5000 Arlington Centre Boulevard, Columbus, $\mathrm{OH} 43220$, 1-800-848-8199.

Congressional Quarterly, Inc., 1414 22nd St., N.W., Washington, D. C. 20037, 1-800-543-7793.

Dow Jones \& Co., Inc., 200 Liberty Street, New York, NY 10281, 1- 800-841-8000, ext. 248.

GEnie (General Electric Network for Information Exchange), 401 N. Washington Boulevard, Rockville, MD 20850, 1-301-340-4000.

Institute of Government, CB \#3330, Knapp Bldg., University of North Carolina at Chapel Hill, Chapel Hill, NC 27599-3330, 1-919-966-4119.

Legislative Services Office, 2129 State Legislative Building, Raleigh, NC 27601-1096, 1-919-733-7044.

LOGIN Information Services, 245 6th St. East, Suite 809, St. Paul, MN 55101-9006, 1-800-328-1921.

National Journal, 1730 M Street, N.W., Washington, DC 20036, 1- 800-424-2921.

North Carolina Agency for Public Telecommunications, 116 W. Jones St., Raleigh, NC 276038003, 1-919-733-6341.

North Carolina Association of County Commissioners, P. O. Box 1488, Raleigh, NC $27602-$ 1488, 1-919-832-2893, (Contact: Debra Holley).

North Carolina Center for Public Policy Research, P. O. Box 430, Raleigh, NC 27602, 1-919-832-2839.

North Carolina. Department of the Secretary of State, 300 N. Salisbury St., Raleigh, NC 27603, 1-919-733-7355.

North Carolina. General Assembly. Senate. Principal Clerk, 2020 State Legislative Building, Raleigh, NC 27601-1096, 1-919-733- 7761.

Southern Bell Telephone Company, P. O. Box 30188, Charlotte, NC 28230, 1-704-378-7799.

\section{References}

1Thomas J. Meyer, The New York Times Magazine (15 Mar. 1992), Section 6, 46.

${ }^{2}$ For information on uses of the Washington Alert Service at the Perkins Library of Duke University, see Stuart Basefsky, "University [Duke] Use of CQ's Washington Alert Service,"

The Docket: Newsletter of the Documents Section of the North Carolina Library Association 19 (Winter 1992): 8.

${ }^{3}$ For an evaluation of online news sources, see Ellen D. Briscoe and Catherine Wall,

"Inexpensive News Sources," Database 15 (Feb. 1992): 28-35. 


\title{
North Carolina Library Association Minutes of the Executive Board
}

\author{
January 17, 1992
}

The Executive Board of the North Carolina Library Association met on January 17, 1992 at the Caraway Conference Center in Asheboro, N. C. The meeting was the culmination of the executive board retreat. President Janet Freeman called the meeting to order at 9:36 a.m.

The members of the executive board and committee chairpersons present at the meeting included the following: Larry Alford, Janet Freeman, Barbara Page, Allen Antone, Jim Govern, Nona Pryor, Frances Bradburn, Araby Greene, Karen S. Purcell, Doris Anne Bradley, Benjie Hester, Vanessa Ramseur, Barbara Baker, Michael Ingram, Ed Shearin, Waltrene Canada, Gwen Jackson, Susan Squires, Wanda Cason, Gene Lanier, Steve Sumerford, Eleanor Cook, Jessica MacPhail, Helen Tugwell, David Fergusson, Cheryl McLean, Catherine Van Hoy, Martha Fonville, Meralyn Meadows, Alice Wilkins.

Howard McGinn and Jane Moore, of the State Library; Jane Barringer, President of the N. C. Friends of Public Libraries and Eleanor Swaim of the Commission on Libraries, were the invited guests in attendance.

The minutes of the previous meeting were distributed. President Freeman asked that the minutes be read and corrections made at that time. Nona Pryor indicated that her name had been omitted from the list of those in attendance. With no other corrections, it was moved by Barbara Baker and seconded by Araby Greene that the minutes be approved as corrected. The motion carried.

For future reference, President Freeman informed the board that minutes of previous meetings would be mailed to board members prior to the meetings.

The treasurer's report, as presented by Wanda Cason, reflected total funds to account for as $\$ 71,121.82$, with expenditures of $\$ 48,008.47$ and a balance of $\$ 23,113.35$ on hand in both checking accounts. The detailed treasurer's report, dated 10/1/91 through $12 / 31 / 91$ was discussed and distributed to board members present.

NCLA Administrative Assistant, Martha Fonville, distributed membership reports to section and round table chairpersons, along with a schedule of the 1992 executive board meetings and a list of committee chairpersons for 1991-93. In addition, an updated list of executive board members was distributed to those members who had not received NCLA Handbooks. Ms. Fonville offered her assistance to the executive board.
Prior to calling for committee reports, President Freeman asked the board to consider the feasibility of requesting that issues to be brought before the board for consideration be submitted to the administrative assistant 30 days prior to the meeting. This information would be distributed to the board prior to the meeting along with the minutes and agenda and would permit consideration of these issues prior to the request for action. Martha Fonville agreed to mail a post card to the board to serve as a reminder to submit this information before the deadline. President Freeman emphasized that this would not mean that new business could not be brought before the board at the meeting; but that advanced notice might permit more informed decision making regarding issues brought before the board. The board felt that this recommendation was feasible and agreed to it.

COMMITTEE AND OTHER REPORTS Archives Committee chairperson, Cheryl McLean, reported that the committee is working to preserve the tapes of the 1953 merger conference.

Gene Lanier, of the Intellectual Freedom Committee, reported that seven cases of infractions of intellectual freedom were currently in process.

Steve Sumerford, of the Literacy Committee, shared with the board copies of the NCLA Literacy Newsletter which highlighted several literary projects being initiated through the committee.

Doris Anne Bradley, of the Constitution, Codes and Handbook Revision Committee, advised the board to replace the old pages of the handbook with the newly revised ones.

North Carolina Libraries editor, Frances Bradburn, reported that her executive board had decided to make changes in format and features beginning with the Spring 1992 issue. The first decision was to publish one article unrelated to the theme in each issue of the journal. This decision was prompted by the increasing number of unsolicited manuscripts received each year. The second was the addition of a new column entitled, "Lagniappe North Caroliniana", which will review non-book formats published in North Carolina. Additionally, the board decided to publish a fifth issue in early fall 1992. This issue entitled, "Crisis in Librarianship", will focus on the future of libraries and librarianship. At the conclusion of the report, editor Bradburn moved for permission from the NCLA Executive Board to deviate from the traditional conference issue in 
1993. Instead, a standard theme issue with conference highlights and biennial reports would be published. She explained that this change would alleviate the stress of attempting to publish all the conference papers. It was agreed that the editorial board would be committed to providing a historical record of the conference. After discussion, the motion carried.

In the absence of ALA Counselor, Pat Langelier, President Freeman indicated that there was no report but that the ALA Counselor solicited concerns from the board to be taken before ALA Council at Mid-Winter.

David Fergusson, SELA Representative, reported on the upcoming SELA Conference to be held in New Orleans, March 17-21, 1992. President Freeman announced that NCLA would have a table at the conference and that she would represent NCLA at the first general session.

\section{SECTION AND ROUND TABLE REPORTS Mike Ingram,} Resources and Technical Services Section chairperson, reported that the section's first official meeting would be in late January or early February and focus on plans for the RTSS Fall Conference. In the interest of cooperative ventures, he solicited any possibilities of a joint conference with another section.

North Carolina Library Paraprofessional Association chairperson, Meralyn Meadows, reported that the main speaker and the table talks from the NCLA Conference were taped and available for check out on Interlibrary loan from the State Library.

Araby Greene, chairperson of the Documents Section, informed the board that Sally Ensor was elected vice-chair/ chair-elect of the section and was gathering information on the feasibility of hosting a workshop on the European Community in late May. She also reported that the section is encouraging electronic communication among documents librarians in the state and that Arlene Hanerfeld has contacted Congressman Charlie Rose in attempts to establish a forum for discussion of depository library concerns.

Public Library Section chairperson, Jim Govern, reported that the executive board created a committee on the Americans with Disabilities Act (ADA) to provide good information as to how it affects public libraries.

David Fergusson appended his remarks with the announcement that Leland Park and Edward Holley had been nominated for the SELA Rothrock Award.

Nona Pryor, chairperson of the North Carolina Association of School Librarians, discussed three issues being addressed by the school librarians. One was the joint venture between NCASL and Children's Services to select the first North Carolina Children's Book Award recipient. The second was the possibility of hiring a lobbyist to work for greater visibility in the state legislature and address issues of concern to media coordinators. Third was the meetings with superintendents regarding the length of the school day and year and its implications for the media programs. She announced the next NCASL Biennial Work Conference to be held September 30-October 2, 1992 at the Sheraton Imperial in Research Triangle Park.
Karen Purcell reported that the Round Table on the Status of Women in Librarianship would also focus on the crisis in libraries and present a debate between Dr. Marilyn Miller and Howard McGinn in August 1992.

Vanessa Ramseur reported that the Round Table on Ethnic Minority Concerns would have its organizational meeting in February. At this meeting it would plan for the biennium and concentrate on a membership drive.

OLD BUSINESS Barbara Baker announced the Currents Conference to be held June 11-12, 1992 in Chapel Hill at the Friday Center. She encouraged librarians' participation.

NEW BUSINESS President Freeman called for new business. Frances Bradburn took this opportunity to advise the board of the availability of a public relations and marketing service called "Team Media" for the purposes of investigating logos and graphic art work for use by the sections or the entire association. Ed Shearin commented that the membership committee was considering new logos for the brochure.

President Freeman invited State Librarian, Howard McGinn, to make remarks. In response, he discussed the public service announcements aired during the ACC games and thanked the association for its support. State Librarian McGinn also announced that the State Library and the North Carolina Friends of Public Libraries would cosponsor the "North Carolina Center for the Book" at the Annual Friends Meeting, April 11, 1992. He announced that it is the 180th anniversary of the State Library. In addition, he mentioned that the vacant seat on the State Library Commission had been filled and that a cooperative venture with North Carolina Central University, School of Library and Information Science would result in a course being taught by satellite beginning in the fall of 1992 .

Eleanor Swaim, of the State Library Commission, was invited to give remarks concerning the commission and her association with it. She mentioned that the National Commission on Libraries had its 20th anniversary this year. She also stated that the governor would be presented with a summary report of the White House Conference.

President Freeman requested that the board take time to reflect on the group initiatives that were generated at the retreat the day before. The three major initiatives were: (1) marketing/public relations, (2) lobbying and (3) continuing to work as an association. She suggested that the services of the governmental relations and marketing and public relations committees be utilized to assist in the development of positive marketing and public relations strategies. She agreed to convey the suggestions made by the board to the chairpersons of those committees. It was suggested that the board not negate the possibility of hiring a lobbyist because of budgetary constraints. It was also suggested that it continue to serve the association as it had in the past.

There being no further discussion, the president declared the meeting of the executive board adjourned at 11:30 a.m. 


\section{Aвout the Authors}

Katherine R. Cagle

Education: B.S. Radford College; M.L.S. University of North Carolina at Greensboro

Position: Library/Media Coordinator, R. J. Reynolds High School, Winston-Salem

Betsy L. Cochrane

Education: B.A. Meredith College

Position: Senator (23rd District), North Carolina General Assembly

Dale Gaddis

Education: A.B. Duke University; M. of Librarianship, Emory University

Position: Director, Durham County Public Library

Plummer Alston Jones, Jr.

Education: B.M. East Carolina University; M.S. Drexel University;

Ph.D. University of North Carolina at Chapel Hill

Position: Head Librarian/Director of Learning Resources, Elon College

Patricia A. Langelier

Education: B.A. Boston State College; M.S.L.S. University of North Carolina at Chapel Hill

Position: Librarian, Institute of Government, University of North Carolina at Chapel Hill

Josephus Mavretic

Education: B.A. University of North Carolina at Chapel Hill;

M.S. The George Washington University

Position: Representative (8th District), North Carolina General Assembly

Howard F. McGinn

Education: B.A. Villanova University; M.S.L.S. Drexel University;

M.B.A. Campbell University

Position: Director, North Carolina Division of State Library, Raleigh

\section{Edward Sheary}

Education: B.A. University of North Carolina at Asheville;

M.S.L.S. University of North Carolina at Chapel Hill

Position: Director, Asheville-Buncombe Library System

Benjamin F. Speller, Jr.

Education: B.A. North Carolina Central University; M.A., Ph. D. Indiana University

Position: Dean and Professor, School of Library and Information Sciences,

Jerry Thrasher North Carolina Central University, Durham

Education: B.A. University of Alabama; M.S.L.S. Florida State University

Position: Director, Cumberland County Public Library and Information Center

John Welch

Education: B. Mus. Memphis State University; M.S.L.S. The Catholic University of America

Position: Assistant Director, North Carolina Division of State Library, Raleigh 
PRESIDENT

Janet L. Freeman

College Librarian

Carlyle Campbell Library

Meredith College

3800 Hillsborough St.

Raleigh, NC 27607-5298

Telephone: $\quad 919 / 829-8531$

Fax: 919/829-2830

\section{VICE PRESIDENT/}

PRESIDENT ELECT

Gwen Jackson

Instructional Specialist

Southeast Technical Assistance Ctr.

2013 Lejeune Blvd.

Jacksonville, NC 28546

Telephone: $\quad 919 / 577-8920$

Fax: $\quad 919 / 577-1427$

\section{SECRETARY}

Waltrene M. Canada

Head, Public Services Division

F. D. Bluford Library

Documents Department

NC A \& T State University

Greensboro, NC 27411

Telephone: 919/334-7617

Fax: $\quad 919 / 334-7783$

\section{TREASURER}

Wanda Brown Cason

Head of Cataloging

PO Box 7777 Reynolda Station

Wake Forest University Library

Winston-Salem, NC 27109-7777

Telephone: 919/759-5094

Fax: $\quad 919 / 759-9831$

\section{DIRECTORS}

Edward (Ed) T. Shearin, Jr.

Director of Library/Learning

Resources Learning Resources Ctr.

Carteret Community College

3505 Arendell St.

Morehead City, NC 28557-2989

Telephone: $\quad 919 / 247-3134$

Fax: $\quad 919 / 247-2514$

Helen M. Tugwell

Coordinator of Media Services

Guilford County Schools

120 Franklin Blvd.

Greensboro, NC 27401

Telephone: $\quad 919 / 271-0640$

Fax: $\quad 919 / 271-0789$

\section{ALA COUNCILOR}

Patricia A. Langelier

Librarian, Institute of

Government

CB 3330 - Knapp Building

UNC at Chapel Hill

Chapel Hill, NC 27599

Telephone: $\quad 919 / 966-4130$ or 919/966-4139

Fax: 919/966-4762
SELA REPRESENTATIVE

David Fergusson

Assistant Director

Headquarters Forsyth Co. Pub. Lib.

660 W. Fifth St.

Winston-Salem, NC 27101

Telephone: 919/727-2556

Fax: $\quad 919 / 727-2549$

EDITOR, Norit Carolina Libraries

Frances Bradburn

Joyner Library

East Carolina University

Greenville, NC 27858-4353

Telephone: 919/757-6076

Fax: $\quad 919 / 757-6618$

\section{PAST-PRESIDENT}

Barbara Baker

Associate Dean for Educational

Resources

Durham Technical

Community College

1637 Lawson St.

Durham, NC 27703

Telephone: $\quad$ 919/598-9218

Fax: $\quad 919 / 598-9412$

\section{ADMINISTRATIVE ASSISTANT \\ Martha Fonville \\ Telephone: 919/431-4452 \\ Fax: \\ 919/431-1809}

North Carolina Library Association c/o State Library of North Carolina Rm. 27109 E. Jones St.

Raleigh, NC 27601-1023

Telephone: $\quad 919 / 839-6252$

Fax: $\quad 919 / 839-6252$

\section{SECTION CHAIRS \\ CHILDREN'S SERVICES SECTION \\ Benjie Hester \\ Children's Librarian \\ Cameron Village Regional Library \\ 1930 Clark Ave. \\ Raleigh, NC 27605 \\ Telephone: $\quad 919 / 856-6723$ \\ Fax: $\quad 919 / 856-6722$}

COLLEGE AND UNIVERSITY SECTION

Susan M. Squires

Reference Librarian

Carlyle Campbell Library

Meredith College

3800 Hillsborough St.

Raleigh, NC 27607-5298

Telephone: $\quad 919 / 829-8382$

Fax: $\quad 919 / 829-2830$

COMMUNITY AND JUNIOR

COLLEGE LIBRARIES SECTION

Alice Wilkins

Head Librarian

Boyd Library

Sandhills Community College

2200 Airport Rd.

Pinehurst, NC 28374

Telephone: 919/692-6185

ext. 135

Fax:

919/692-2756
DOCUMENTS SECTION

Araby Greene

Documents Librarian

D. Hiden Ramsey Library

UNC at Asheville

One University Heights

Asheville, NC 28804-3299

Telephone: $\quad 704 / 251-6639$

Fax: $\quad 704 / 251-6012$

GREENE@UNCA.BITNET SECTION

LIBRARY ADMINISTRATION AND

MANAGEMENT SECTION

Larry Alford

Associate University Librarian for Administrative Services

CB 3900 - Walter R. Davis Library

UNC at Chapel Hill

Telephone: $\quad$ 919/962-1301

Fax:

919/962-0484

NORTH CAROLINA ASSOCIATION

OF SCHOOL LIBRARIANS

Nona Pryor

Media Specialist

Archdale-Trinity Middle School

Trinity, NC 27370

NORTH CAROLINA PUBLIC LIBRARY TRUSTEES ASSOCIATION

Barbara Page

125 W. Queen St.

Hillsborough, NC 27278

Telephone: $\quad$ 919/732-2410 (h)

Fax: $\quad$ 919/644-1710

PUBLIC LIBRARY SECTION

James Govern

Director Stanly Co. Pub. Library

133 E. Main St.

Albemarle, NC 28001-4993

Telephone: 704/983-7321

Fax: $\quad 704 / 983-7322$

REFERENCE AND ADULT SERVICES

Allen Antone

Head of Reference Belk Library

Appalachian State University

Boone, NC 28608

Telephone: $\quad 704 / 262-2822$

Fax: 704/262-3001

RESOURCES AND TECHNICAL

SERVICES SECTION

Mike Ingram,

Technical Services Librarian

Smith Library

HP-2 High Point College

High Point, NC 27261-1949

Telephone: $\quad$ 919/841-9152

Fax:

919/841-5123
Chapel Hill, NC 27599-3900
ROUND TABLE CHAIRS

NEW MEMBERS ROUND TABLE

Catherine Van Hoy

Branch Head Cumberland

County Public Library

Bordeaux Branch

3711 Village Dr.

Fayetteville, NC 28304-1598

Telephone: 919/424-4008

Fax:

919/483-8644

NORTH CAROLINA LIBRARY

PARAPROFESSIONAL ASSOCIATION

Meralyn Meadows

Administrative Assistant

Stanly County Public Library

133 E. Main St.

Albemarle, NC 28001-4993

Telephone: $\quad 704 / 983-7322$

Fax:

$704 / 983-7322$

ROUND TABLE FOR ETHNIC

MINORITY CONCERNS

Vanessa Ramseur

7207 E. W. T. Harris Blvd.

Charlotte, NC 28227

Telephone: $\quad$ 919/563-9418

Fax:

919/567-9703

\section{ROUND TABLE ON SPECIAL}

COLLECTIONS

Beverly Tetterton-Opheim

Special Collections Librarian

New Hanover Co. Public Library

201 Chestnut St.

Wilmington, NC 28401-3998

Telephone: $\quad 919 / 341-4394$

Fax:

$919 / 341-4388$

ROUND TABLE ON THE STATUS

OF WOMEN IN LIBRARIANSHIP

Karen Seawell Purcell

Director of Information Services

Greensboro AHEC

1200 N. Elm St.

Greensboro, NC 27401

Telephone: $\quad 919 / 379-4483$

Fax:

919/379-3591 


\section{Editor}

FRANCES BRYANT BRADBURN

Joyner Library

East Carolina University

Greenville, NC 27858-4353

(919) 757-6076

Associate Editor

ROSE SIMON

Dale H. Gramley Library

Salem College

Winston-Salem, NC 27108

(919) $721-2649$

Associate Editor

JOHN WELCH

Division of State Library

109 East Jones Street

Raleigh, NC 27601-2807

(919) $733-2570$

Book Review Editor ROBERT ANTHONY

CB\#3930, Wilson Library University of North Carolina Chapel Hill, NC 27599-3930 (919) $962-1172$

\section{Lagniappe/Bibliography}

Coordinator

PLUMMER ALSTON JONES, JR. Iris Holt McEwen Library

Elon College

PO Box 187

Elon College, NC 27244

(919) 584-2338
Advertising Manager

HARRY TUCHMAYER

New Hanover Co. Public Library

201 Chestnut Street

Wilmington, NC 28401

(919) 341-4036

Editorial Advisor

HOWARD F. McGINN

Division of State Library

109 East Jones Street

Raleigh, NC 27601--2807

(919) $733-2570$

Trustees

MRS. ERNEST M. KNOTTS

Route 2, Box 505

Albemarle, NC 28001

(704) $982-7434$

\section{Children's Services}

LINDA HYDE

Clemmons Branch

Forsyth County Public Library

3554 Clemmons Road

Clemmons, NC 27012

(919) 766-9191

College and University MELISSA CAIN

School of Information \&

Library Science

CB \#3360, 100 Manning Hall

University of North Carolina

Chapel Hill, NC 27599-3360

(919) 962-8366
Community and Junior College

BARBARA MILLER

Paul H. Thompson Library

Fayetteville Technical

Community College

PO Box 35236

Fayetteville, NC 28303

(919) 678-8253

Documents

LISA K. DALTON

Rockingham CountyPublicLibrary

598 Pierce Street

Eden, NC 27288

(919) 623-3168

New Members Round Table DOROTHY DAVIS HODDER

Public Services Librarian

New Hanover Co. Public Library

201 Chestnut Street

Wilmington, NC 28401

(919) 341-4389

\section{N.C. Association of School}

Librarians

DIANE KESSLER

Riverside High School 3218 Rose of Sharon Road

Durham, NC 27712

(919) 560-3965

North Carolina Library

Paraprofessional Association JUDIE STODDARD

Onslow County Public Library

68 Doris Avenue East

Jacksonville, NC 28540

(919) $455-7350$
Public Library

BOB RUSSELL

Elbert Ivey Memorial Library

420 Third Street NW

Hickory, NC 28601

(704) $322-2905$

Reference/Adult Services

SUZANNE WISE

Belk Library

Appalachian State University

Boone, NC 28608

(704) 262-2189

Research Column Editor

ILENE NELSON

William R. Perkins Library

Duke University

Durham, NC 27706

(919) 684-2373

Resources and Technical Services GENE LEONARDI

Shepard Library

North Carolina Central University Durham, NC 27707

(919) 560-6220

Round Table for Ethnic/Minority Concerns

BELINDA DANIELS

Learning Resources Center Guilford Technical Com. College Jamestown, NC 27282-2309

(919) 334-4822

Round Table on the Status of Women in Librarianship ELIZABETH LANEY 602 Hamlin Park Chapel Hill, NC 27514

(919) 942-1416

Name

New membership

Position Library

Business Address

City or Town State Zip Code Phone No. Mailing Address (if different from above)

\section{CHECK TYPE OF DUES}

FULL-TIME LIBRARY SCHOOL STUDENTS

(one biennium only) $-\$ \underline{15.00}$

RETIRED LIBRARIANS $-\$ 20.00$

NON-LIBRARY PERSONNEL:

(a) Trustees; (b) "Friends of Libraries" members;

(c) Non-salaried - $\$ 25.00$

LIBRARY PERSONNEL

Earning up to $\$ 15,000-\$ 25.00$

Earning $\$ 15,001$ to $\$ 25,000-\$ \underline{40.00}$

Earning $\$ 25,001$ to $\$ 35,000-\$ \underline{50.00}$

Earning $\$ 35,001$ and above $-\$ 60.00$

INSTITUTIONAL (Libraries and library/educationrelated businesses) $-\$ 75.00$

CONTRIBUTING (Individuals, associations, firms, etc. interested in the work of NCLA) $-\$ 100.00$
CHECK SECTIONS: (one included in basic dues; each additional section \$7.00)

$\square$ Children's Services $\quad \square$ New Members

Ref. \& Adult

College \& Univ

Comm. \& Jr. College

Documents

Paraprofessional

Special Collections

Public Library

Trustees

Status of Women

Ethnic Minority Concerns

Library Administration \& Management

NCASL (School Librarians)

Resource and Technical Services

Mail to: North Carolina Library Association, c/o State Library of North Carolina,

109 East Jones Street, Raleigh, NC 27601-1023 


\section{BIRDS OF THE BLUE RIDGE MOUNTAINS}

A Guide for the Blue Ridge Parkway, Great Smoky Mountains, Shenandoah National Park, and Neighboring Areas by Marcus B. Simpson, Jr. Illustrations by $\mathrm{H}$. Douglas Pratt

This detailed guide refers vacationers, birdwatchers, and professional ornithologists to optimal birding localities in the Blue Ridge province and describes the abundant birdlife waiting to be seen there.

2018-0, \$29.95 cloth 4363-6, \$14.95 paper 22 b\&w illus., 27 maps A Selection of the Birding Book Club

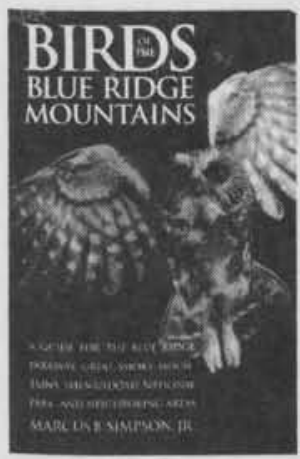

\section{WALKING THE \\ BLUE RIDGE}

A Guide to the Trails of the Blue Ridge Parkway by Leonard M. Adkins

"An indispensable guide for anyone who enjoys the mountains of Virginia and North Carolina.... A treasure chest full of gems to be found off the beaten path."-The State

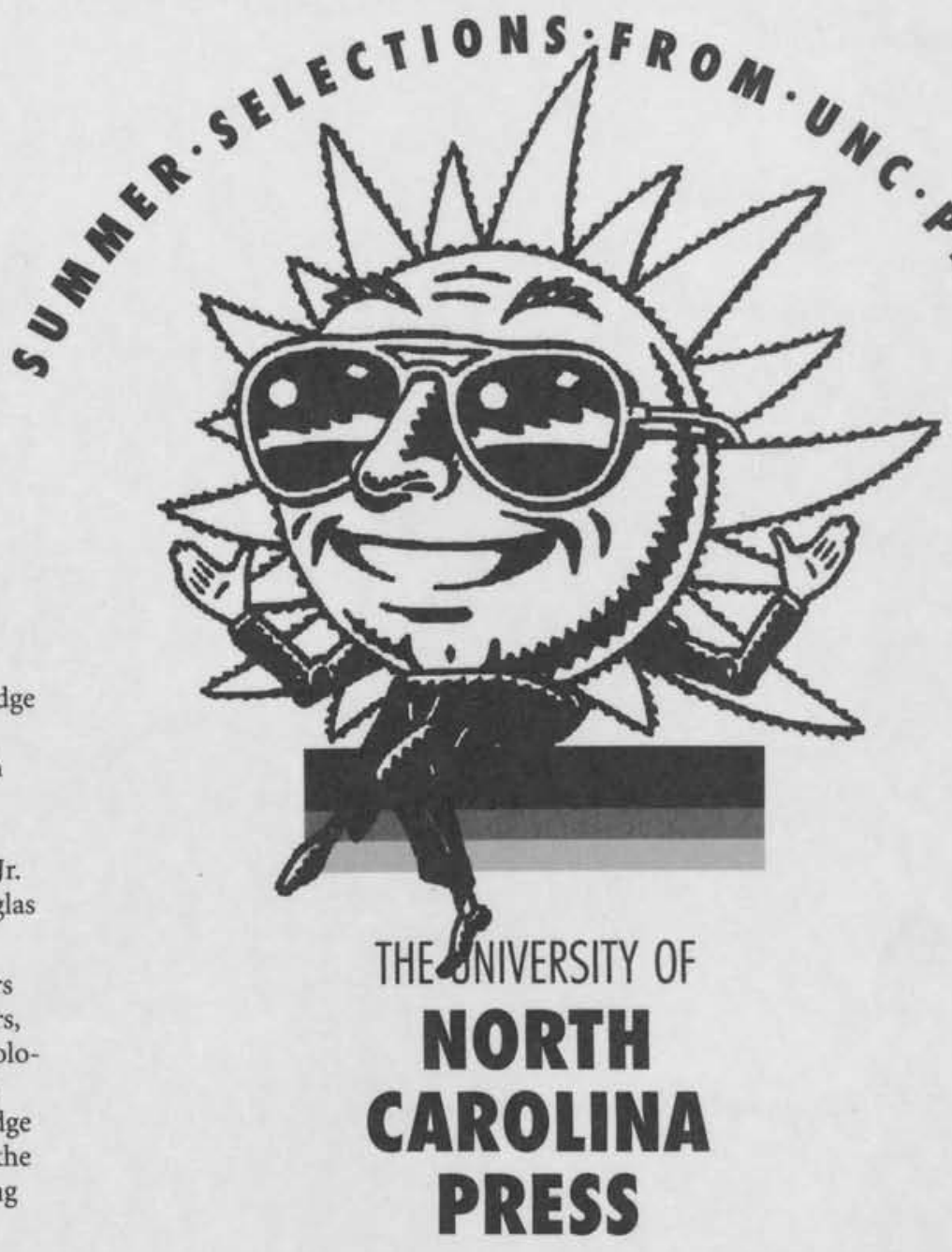

POST OFFICE BOX 2288, CHAPEL HILL, NC 27515-2288

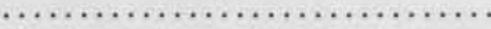

\section{GROWING AND PROPAGATING SHOWY NATIVE WOODY PLANTS}

by Richard E. Bir

A complete reference for gardening with native trees and shrubs, an area of growing interest for both horticulturists and backyard gardeners. Richard Bir describes the ease and striking rewards of landscaping with flowering and fruit-producing plants native to the eastern United States.

2027-X, \$29.95 cloth 4366-0, \$18.95 paper

82 color illus., 25 line drawings A Selection of the Garden Book Club

\section{LIGHT ON THE HILL}

A History of The University of North Carolina at Chapel Hill

by William D. Snider

William Snider provides a rich chronicle of the signal events in Carolina's history and an illuminating portrait of the individuals whose vision helped to create the university's unique environment. 2023-7, \$24.95 45 illus.

\section{ISBN prefix ()-8078}

\section{NORTH CAROLINA AND} OLD SALEM COOKERY

New and Revised Edition by Beth Tartan

Written by the former Winston-Salem Journal food editor and in print for more than 25 years, this collection is the acknowledged classic on North Carolina cuisine. Features dozens of new recipes and a captivating chapter on Moravian cookery.

2035-0, \$29.95 cloth 4375-X, \$16.95 paper A Chapel Hill Book

\section{Back in print}

\section{AUNT ARIE}

A Foxfire Portrait

Edited by Linda Garland Page and Eliot Wigginton

An extraordinary portrait of Arie Carpenter, the colorful heroine of the Foxfire projects and inspiration for Jessica Tandy's Broadway role. 4377-6, \$14.95 paper 115 illus.

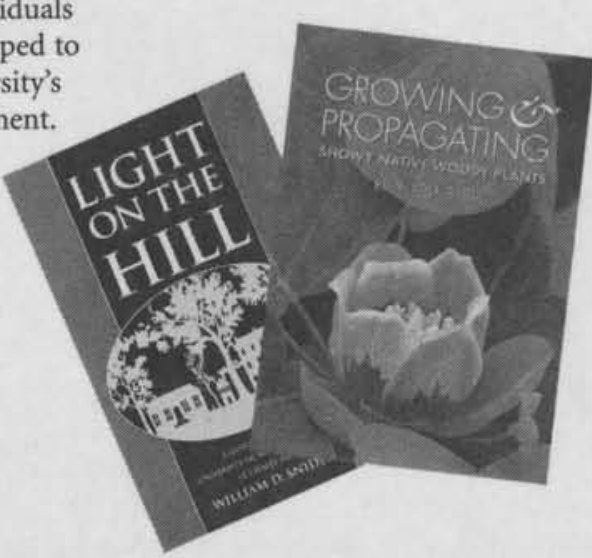




\title{
Upcoming Issues
}

\author{
Fall 1992 Telecommunications \\ Bill Stahl, Guest Editor
}

\section{Winter 1992 Popular Culture and'Libraries Alice Cotten and Eileen McGrath,Guest Editors}

Spring 1993 Ethics in Librarianship Marti Smith, Guest Editor

Summer 1993 Children's Services
Satia Orange and Cal Shepard, Guest Editors

Fall 1993 Social Issues in Librarianship Jane Moore, Guest Editor

Winter 1993 Conference Issue

Unsolicited articles dealing with the above themes or any issue of interest to North Carolina librarians are welcomed. Please contact the editor for manuscript guidelines and deadlines.

Norit Carolina Libraries, published four times a year, is the official publication of the North Carolina Library Association. Membership dues include a subscription to Norit Carolina Libraries. Membership information may be obtained from the Administrative Assistant of NCLA. Subscription rates are $\$ 32.00$ per year, or $\$ 10.00$ per issue, for domestic subscriptions; $\$ 50.00$ per year, or $\$ 15.00$ per issue, for foreign subscriptions. Backfiles are maintained by the editor. Microfilm copies are available through University Microfilms. Norit Carolina Libraries is indexed by Library Literature and publishes its own annual index. Editorial correspondence should be addressed to the editor; advertisement correspondence should be addressed to the advertising manager. Articles are juried. 